\title{
The National Energy Technology Laboratory Annual Site Environmental Report for Calendar Year 2000
}

October 2001

U.S. Department of Energy

National Energy Technology Laboratory

Pittsburgh, Pennsylvania

Morgantown, West Virginia

NETL Customer Service Line: (800) 553-7681

NETL Homepage: www.netl.doe.gov 


\section{Disclaimer}

Reference herein to any specific commercial product, process, or service by trade name, trademark, manufacturer, or otherwise does not necessarily constitute or imply its endorsement, recommendation, or favoring by the United State Government or any agency thereof. The views and opinions of authors expressed herein do not necessarily state or reflect those of the United States Government or any agency thereof.

Available to DOE employees and contractors from the Office of Scientific and Technical Information, P.O. Box 62, 175 Oak Ridge Turnpike, Oak Ridge, TN 37831; prices are available by phone: (423) 576-8401; fax: (423) 576-5725; or e-mail: reports@ adonis.osti.gov.

Available to the public from the National Technical Information Service, U.S. Department of Commerce, 5285 Port Royal Road, Springfield, VA 22161; phone orders accepted at (703) 487-4650. 


\section{Preface}

This Site Environmental Report was prepared by the Environment, Safety, and Health Division at the National Energy Technology Laboratory (NETL) for the U.S. Department of Energy. The purpose of this report is to inform the public and Department of Energy stakeholders of the environmental conditions at the NETL sites in Morgantown, West Virginia, and Pittsburgh, Pennsylvania. This report contains the most accurate information that could be collected during the period between January 1 , 2000, through December 31, 2000. As stated in DOE Orders 5400.1 and 231.1, the purpose of the report is to

C Characterize site environmental management performance

C Confirm compliance with environmental standards and requirements

C Highlight significant facility programs and efforts

A reader questionnaire/comment form is included on the following page to provide an opportunity for public input on current and future site environmental reports.

\section{Office of Fossil Energy}

\section{Commitment to Environment, Safety and Health}

Fossil Energy is committed to conducting our mission to achieve the greatest benefit for all our stakeholders, including our employees and the public, while actively adhering to the highest standards for environment, safety, and health. Fossil Energy will continuously improve our practices through effective integration of environment, safety, and health into all facets of work planning and execution. Fossil Energy will make consistent, measurable progress in implementing this commitment throughout our operations while striving for zero injuries, incidents, and environmental releases. 


\section{Questionnaire \\ National Energy Technology Laboratory \\ 2000 Site Environmental Report}

Please answer the following questions and return to:

Elias George

National Energy Technology Laboratory - Pittsburgh

P.O. Box 10940

Pittsburgh, PA 15236

If you are viewing the electronic version, you can email your response to george@netl.doe.gov

(1) Was the 2000 Site Environmental Report easy to read and understand? If not, please provide a brief explanation.

(2) Was the information contained in the report useful? Please provide a brief explanation.

(3) Do you feel the report contained all of the information that you would be interested in? If not, please provide a brief explanation.

(4) Do you have any comments or suggestions on how the current and future reports can be improved?

(5) Other comments or suggestions? 


\section{Contents}

Page

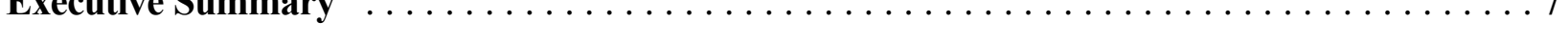

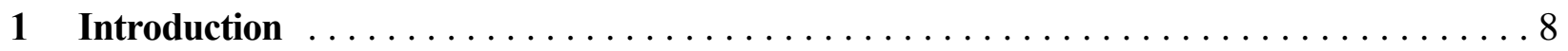

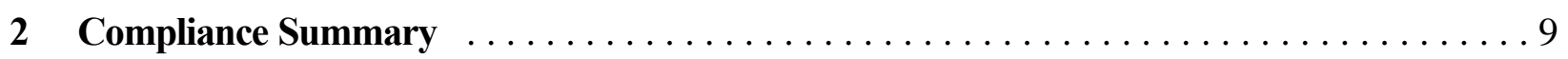

2.1 Comprehensive Environmental Response, Compensation, and Liability Act . . . . . 10

2.2 Superfund Amendment and Reauthorization Act $\ldots \ldots \ldots \ldots \ldots \ldots \ldots \ldots$

$2.3 \quad$ Clean Air Act . . . . . . . . . . . . . . . . . . . . . . . . 14

2.4 Clean Water Act and the National Pollutant Discharge Elimination System . . . . . . 16

2.5 Resource Conservation and Recovery Act $\ldots \ldots \ldots \ldots \ldots \ldots \ldots \ldots$

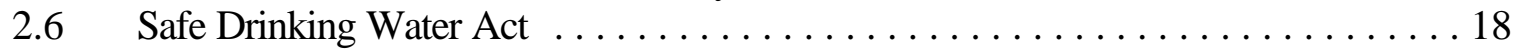

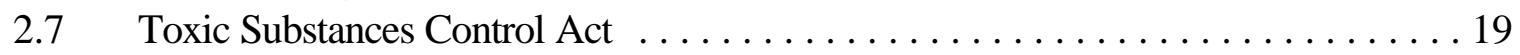

$2.8 \quad$ Federal Insecticide, Fungicide, and Rodenticide Act $\ldots \ldots \ldots \ldots \ldots \ldots \ldots$

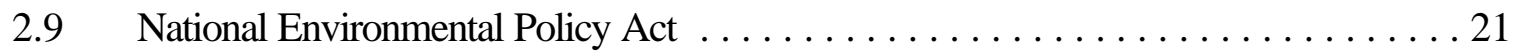

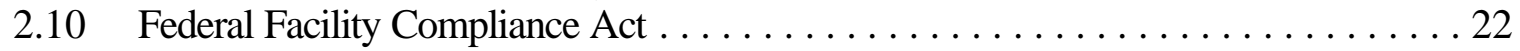

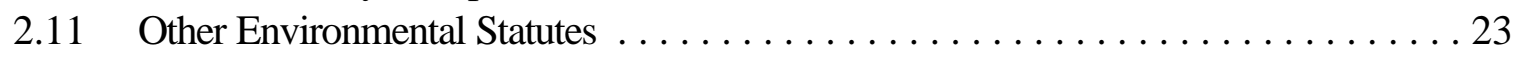

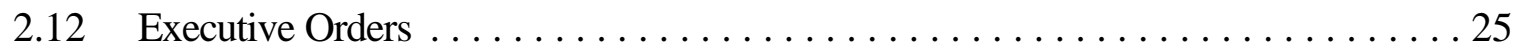

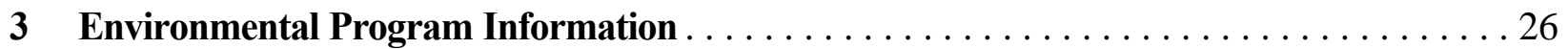

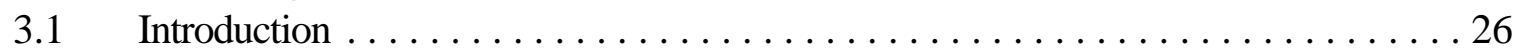

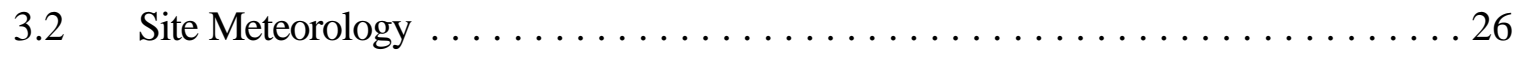

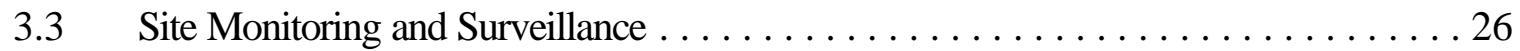

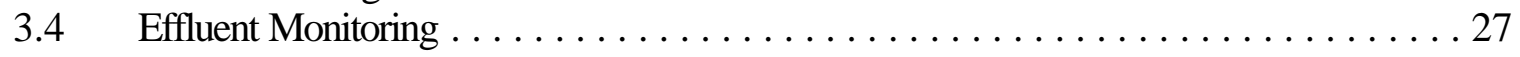

3.5 Other Environmental Issues and Actions $\ldots \ldots \ldots \ldots \ldots \ldots \ldots \ldots \ldots \ldots \ldots \ldots \ldots \ldots \ldots \ldots$

4 Environmental Management Information $\ldots \ldots \ldots \ldots \ldots \ldots \ldots \ldots \ldots \ldots \ldots \ldots$

5 Environmental Radiological Program Information $\ldots \ldots \ldots \ldots \ldots \ldots \ldots \ldots$

6 Environmental Non-Radiological Program Information . . . . . . . . . . . . . . . . 39

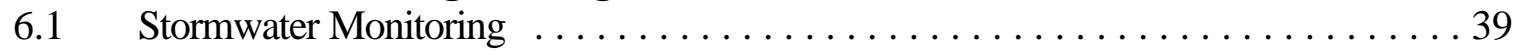

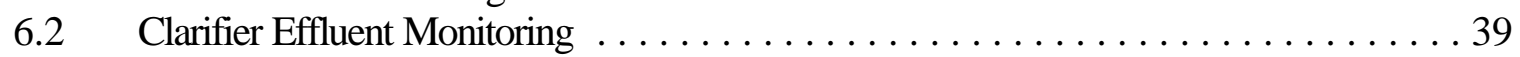

6.3 Waste Minimization . . . . . . . . . . . . . . . . . . 39

7 Site Hydrology, Groundwater Monitoring and Public Drinking Water Protection . . . . . 41

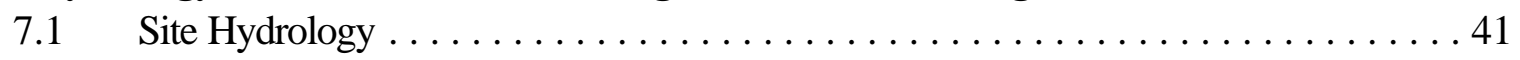

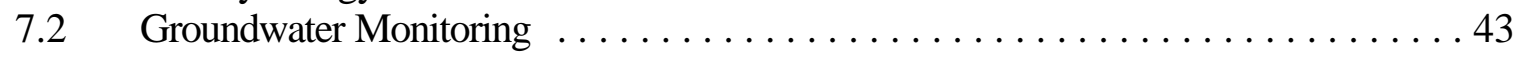

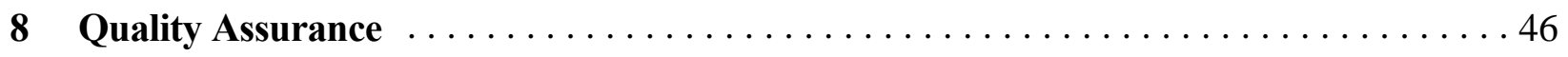

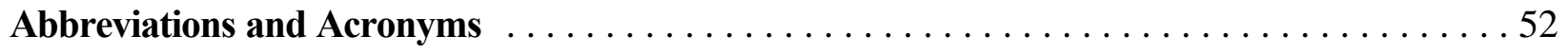

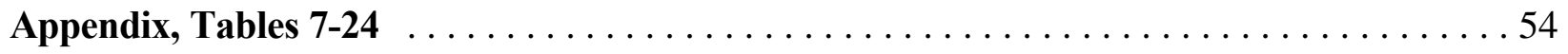




\section{List of Tables}

Table

1 Summary of Environmental Permits . . . . . . . . . . . . . . . . . . 9

2 Emergency Planning and Community Right-to-Know Act Reporting . . . . . . . . . . 12

3 Sara Title III, Tier II Chemical Inventory Reporting List $\ldots \ldots \ldots \ldots \ldots \ldots \ldots \ldots$

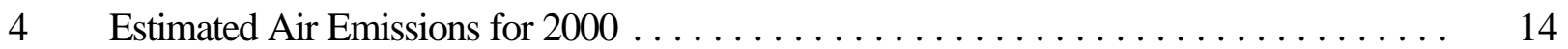

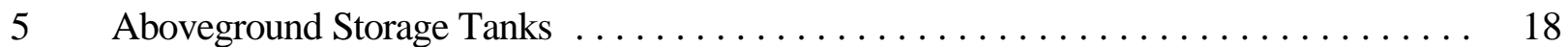

$6 \quad$ NETL Radioactive Materials Inventory for $2000 \ldots \ldots \ldots \ldots \ldots \ldots \ldots \ldots \ldots$

7 NETL 2000 National Pollutant Discharge Elimination System Storm Water Analysis Results 54

8 NETL 2000 Wastewater Effluent Analysis . . . . . . . . . . . . . . . . . . 55

9 NETL-PGH Industrial Sewer Use Permit Monitoring Analysis . . . . . . . . . . . . . . 57

10 NETL-PGH 2000 Groundwater Detection Monitoring Program, Results of Analysis -

Groundwater Samples, Main Plateau - Contamination Indicator Constituents . . . . . . 58

11 NETL-PGH 2000 Groundwater Detection Monitoring Program, Results of Analysis Groundwater Samples, Valley Fill - Contamination Indicator Constituents . . . . . . . . . 60

12 NETL-PGH 2000 Groundwater Detection Monitoring Program, Results of Analysis Groundwater Samples, Main Plateau - Groundwater Characteristics Constituents . . . . . 62

13 NETL-PGH 2000 Groundwater Detection Monitoring Program, Results of Analysis Groundwater Samples, Valley Fill - Groundwater Characteristics Constituents . . . . . . 64

14 NETL-PGH 2000 Groundwater Detection Monitoring Program, Results of Analysis Groundwater Samples, Main Plateau - Semivolatile Organic Compounds Constituents . 66

15 NETL-PGH 2000 Groundwater Detection Monitoring Program, Results of Analysis Groundwater Samples, Valley Fill - Semivolatile Organic Compounds Constituents . . . . 68

16 NETL-PGH 2000 Groundwater Detection Monitoring Program, Results of Analysis Groundwater Samples, Valley Fill - TPH Constituents . . . . . . . . . . . . . . . . . 69

17 NETL-PGH 2000 Groundwater Detection Monitoring Program, Results of Analysis Groundwater Samples, Main Plateau - Volatile Organic Compounds Constituents . . . . 70

18 NETL-PGH 2000 Groundwater Detection Monitoring Program, Results of Analysis Groundwater Samples, Valley Fill - Volatile Organic Compounds Constituents . . . . . . 72

19 NETL-MGN April 2000 Groundwater Data for "Morgantown Aquifer," . . . . . . . . 73

20 NETL-MGN April 2000 Groundwater Data for "A Aquifer," . . . . . . . . . . . . . . 74

21 NETL-MGN April 2000 Groundwater Data for "B-C Aquifer," . . . . . . . . . . . . . 75

22 NETL-MGN August 2000 Groundwater Data for "Morgantown Aquifer" . . . . . . . 76

23 NETL-MGN August 2000 Groundwater Data for "A Aquifer," . . . . . . . . . . . . . . 77

24 NETL-MGN August 2000 Groundwater Data for "B-C Aquifer" . . . . . . . . . . . . . 78 


\section{Executive Summary}

No significant environmental problems were identified at the National Energy Technology Laboratory (NETL) sites in Morgantown (MGN) and Pittsburgh (PGH) during 2000. No radionuclides were released from the site during 2000. The site maintains two major environmental programs: waste management, and environmental media and release management. These two programs encompass waste handling, storage, and disposal, waste minimization and pollution prevention, air quality emissions, surface water discharges, groundwater impacts, industrial wastewater discharges, and spill control procedures. Both sites currently maintain complete monitoring programs for groundwater, stormwater discharge, laboratory wastewater discharge, and meteorological data. In addition, an annual air emissions inventory is prepared for each site.

A comprehensive Directives Program aimed at environmental, safety, health requirements and risks was initiated in 1997, continued through subsequent years, and will be completed in 2001. The primary objective of the program is to identify and implement standards that will protect the health and safety of workers, public, and the environment. This program started with a careful and thorough analysis of risks confronting workers and the communities surrounding NETL sites. Following this analysis, requirements and best management practices were evaluated to determine how requirements could best be used to advance the mission of NETL. Teams of subject-matter experts analyzed the work assigned to determine potential hazards and identify ways to remove or control those hazards. In 2000, NETL developed or revised a series of directives in two major areas: safety analysis and review (SAR) processes, and integrated safety management (ISM) directives. SAR directives were issued for research and development $(\mathrm{R} \& \mathrm{D})$ operations, support operations, and facilities. ISM directives were released on management processes, such as standards maintenance, performance measures, assessments, corrective actions, lessons-learned, and training.

In conjunction with the Directives Program, the use of the voluntary environmental management system, ISO 14000, was evaluated. This includes the only environmental management standard to which an entity can be registered. NETL is considering using the specifications and guidance from this standard to identify an effective environmental management system for the NETL sites. Plans were initiated for an outside consultant to perform an environmental management system assessment (also referred to as an initial environmental review), as referenced in ISO 14004. The objective of the assessment will be to determine the degree to which NETL's existing integrated safety management system (ISMS), safety analysis review system (SARS), and environmental management programs conform with the ISO 14001 Environmental Management System (EMS) standard and the United States Environmental Protection Agency's (EPA) Code of Environmental Management Principles.

A performance measurement system continued to be maintained during 2000 to assist in evaluating how effectively activities at NETL meet mission-critical goals and how well missions and strategies are connected in the DOE strategic plan. This system also provides data to assist in gauging performance against the DOE critical success factors, that is, performance against technical objectives. Various environmental milestones can be tracked to completion, thus giving the NETL measures by which to gauge the sites' goals of remaining in regulatory compliance and achieving best-in-class environmental performance. 


\section{Introduction}

The National Energy Technology Laboratory (NETL), located in Morgantown, West Virginia, Pittsburgh, Pennsylvania, and Tulsa, Oklahoma, is a multi-purpose laboratory owned and operated by the U.S. Department of Energy (DOE). NETL conducts and implements science and technology development programs for the Department in energy and energy-related environmental systems. Our organization, formerly the Federal Energy Technology Center, was established in 1996 through consolidation of Energy Technology Centers at Pittsburgh and at Morgantown. In December 1999, NETL was designated the Department's 15th national laboratory, and is now a matrix organization; that is, employees at the Morgantown and Pittsburgh sites operate organizationally under the same management team.

In August 2000, the National Petroleum Technology Office (NPTO) in Tulsa was assimilated into NETL. Environmental activity performed during calendar year 2000 at NPTO is not included in this report; however, NPTO data will be included in the 2001 Annual Site Environmental Report.

This Site Environmental Report is the fifth merged environmental analysis performed on the Pittsburgh and Morgantown sites. We have dedicated ourselves to achieving a seamless environmental program. However, since the sites are more than 60 miles apart and in different states (West Virginia and Pennsylvania) with different regulatory agencies, some reporting and monitoring issues must be discussed separately in this report. 


\section{Compliance Summary}

During 2000, NETL conducted numerous activities to comply with federal, state, and local regulations, internal requirements and Department of Energy (DOE) orders. This report provides information about activities and data related to compliance. This document does not address regulations where no action was required or there is no new information to report.

Programs were conducted to manage air, water, soil, waste, community "Right-to-Know," and other environmental issues. All hazardous wastes were managed and removed from the merged sites within allowable accumulation times specified in Resource Conservation and Recovery Act (RCRA) regulations. Table 1 is a summary of permits related to environmental activities conducted in 2000.

\section{Table 1. Summary of Environmental Permits}

\begin{tabular}{|c|c|c|}
\hline Permit Type & Permit Number & Status \\
\hline Air & $\begin{array}{l}\text { MGN: } \\
\text { R13-1768 } \\
0610064 \\
\text { PGH: } \\
7032056-000-00500 \\
7032056-000-00501 \\
7032056-000-0800\end{array}$ & $\begin{array}{l}\text { MGN: } \\
\text { West Virginia Office of Air Quality issues the permits. Right to } \\
\text { Construct and Right to Operate SynGas Generator/PDU. } \\
\text { PGH: } \\
\text { Allegheny County issues the permits. Natural gas boilers used for } \\
\text { heating buildings and one gas-coal fired research unit. }\end{array}$ \\
\hline $\begin{array}{l}\text { Water (non- } \\
\text { NPDES) }\end{array}$ & $\frac{P G H}{G F} 31062.008$ & $\begin{array}{l}\text { Industrial Sewer Use Permit issued by Gannett Fleming Engineers } \\
\text { under contract with the Pleasant Hills Authority. Regulates certain } \\
\text { constituents of process/laboratory wastewater placed into the } \\
\text { sanitary sewer system. }\end{array}$ \\
\hline Water (NPDES) & $\begin{array}{l}\text { MGN: } \\
\text { MUB Permit No. } 012 \\
\text { WV0111457 } \\
\text { PGH: } \\
\text { Part I - PA0025844 } \\
\text { Part II - } 0297201\end{array}$ & $\begin{array}{l}\text { MGN: } \\
\text { All monitored parameters were within permit limitations during } \\
2000 \text {. } \\
\text { PGH: } \\
\text { Part I for a National Pollutant Discharge Elimination System } \\
\text { (NPDES) stormwater discharge permit issued by PaDEP. Part II } \\
\text { for an industrial settling weir owned by NIOSH. All monitored } \\
\text { parameters were within permit limitations during } 2000 \text {. }\end{array}$ \\
\hline Storage Tanks & $\begin{array}{l}\text { PGH: } \\
02-81183008 \mathrm{~A} \\
02-81183009 \mathrm{~A} \\
02-81183010 \mathrm{~A} \\
02-81183012 \mathrm{~A}\end{array}$ & Aboveground storage tank permits issued by $\mathrm{PaDEP}$. \\
\hline Asbestos & $\begin{array}{l}\text { PGH: } \\
\text { PAA99-0292 } \\
\text { PAA00-0243 } \\
\text { PAA00-0517 } \\
\text { PAA00-0519 }\end{array}$ & $\begin{array}{l}\text { Asbestos Abatement Permits Issued through the Allegheny County } \\
\text { Pennsylvania, Health Department, Air Pollution Division. }\end{array}$ \\
\hline
\end{tabular}




\subsection{Comprehensive Environmental Response, Compensation, and Liability Act}

The Morgantown and Pittsburgh sites had no on-site activity relating to the Comprehensive Environmental Response, Compensation, and Liability Act (CERCLA) during 2000; however, the following sections describe CERCLA-related activity at remote sites in other areas of the United States that remains the total or partial responsibility of NETL. These areas continue to be monitored for appropriate environmental responses.

\section{Rock Springs, Wyoming}

In Rock Springs, Wyoming, the Rock Springs Oil Shale Retort site consists of 13 locations where in-situ shale fracturing and retorting research were conducted. As a result of research activities, groundwater was contaminated with organic compounds that must be cleaned up to standards set forth in the Wyoming Environmental Quality Act. Although the site was not listed on the Federal Agency Hazardous Waste Compliance Docket, NETL proactively tasked the Tennessee Valley Authority (TVA) to conduct a preliminary assessment (PA) of the site in 1993, in accordance with CERCLA, to determine if the site should be placed on the national priority list (NPL). After reviewing the PA, which resulted in a score of two, United States Environmental Protection Agency (EPA) Region VIII classified the site as "site evaluation accomplished" (SEA) under the Federal Superfund Program and notified NETL that the site would not be evaluated further for inclusion on the NPL. Consequently, DOE must satisfy Wyoming State requirements as defined by the Wyoming Environmental Quality Act.

Pilot demonstrations were designed and constructed at Sites 4/7, 9, and 12. Air injection and bioremediation actions were undertaken at each of the three sites, with a more aggressive air sparge system used at Site 4/7, minimal aeration/water extraction and injection with nutrient injection demonstrated at Site 9, and minimal air injection/water extraction and injection at Site 12. The demonstrations were conducted through August 2000, at which time an evaluation was conducted to determine the preferred remedial alternative for each site, as required by the National Environmental Policy Act of 1969 (NEPA).

An Environmental Assessment for the Rock Springs Oil Shale Retort Site was conducted in 2000. The finding of No Significant Impacts was signed on July 31, 2000. Completion of the NEPA process allowed for design and construction of the preferred remedial alternatives to go forward.

Following the pilot demonstration at Site 9, evaluations led to the initiation of designs for an aeration/bioremediation system with water extraction/injection capability. Construction of the system and support buildings began in September 2000. Thirty air injection wells were installed, with eight wells acting as either injection or extraction wells. Two 100-horsepower (HP) electric compressors deliver air to the Site 9 wells. Six additional wells were installed in the well field at Site 4/7, and wells used in the pilot demonstration are being used for site remediation. Four $15 \mathrm{HP}$ compressors deliver air to an aggressive air sparge system in all of the 22 wells in the site 4/7 well field. Sites 4/7 and 9 are showing reductions of benzene, ethyl benzene, toluene, and xylene during the operational period. Site 12 will continue to be observed for biological activity (aerobic and anaerobic), through ground water data evaluation and biological enumeration. A remediation system will be designed following biological bench scale and feasibility studies. 


\section{Gillette, Wyoming}

In Gillette, Wyoming, the Hoe Creek Underground Coal Gasification site consists of three locations where coal was gasified in situ. As a result of the field tests, coal tars remain underground in two coal seams and in the channel sand overburden. Water flowing through the coal and the channel sand has leached organic compounds from source materials into the groundwater, and contaminant levels have exceeded state regulatory limits. Annual pump-and-treat operations have been conducted during summer months as an interim measure, to minimize any contaminated groundwater movement from the boundaries of the R\&D permit area onto private lands. Contaminated groundwater has migrated onto one private landowner's property east of the permit area. From 1994 through 1996, in an attempt to contain the contamination on the permit area, approximately 14,127,000 liters (3,774,000 gallons) of water were pumped, treated by routing through an activated granular carbon system, and applied to the ground surface by a spray system through atomizing nozzles.

The Hoe Creek site was listed on the Federal Agency Hazardous Waste Compliance Docket on June 1, 1991. In accordance with CERCLA requirements, a preliminary assessment (PA) of the Hoe Creek site was conducted in 1993 to determine if the site should be placed on the NPL. After reviewing the PA, which indicated a score of 14, the EPA Region VIII Office classified the site as SEA under the Federal Superfund Program and notified NETL that the site would not be evaluated further for inclusion on the NPL. As a result, requirements imposed by the Wyoming Environmental Quality Act must be met.

On February 7, 1998, the air sparge/bioremediation system was completed at the Hoe Creek II area of the Hoe Creek site. Air is being injected into the Felix I and II aquifers, through 64 wells completed during the construction phase. Two 75-HP electric compressors supply the air necessary for delivery to the groundwater system for air sparging actions. Groundwater samples were extracted three times per year, at 111 day intervals (days 111, 222, 333). The remaining days-per-year were consumed by periods of shutdown before sampling, and start-up periods before resumption of air sparging activities.

Construction of the Hoe Creek III air sparge/bioremediation system was initiated during October 1998, and completed in February 1999. Fifty air sparge wells were completed in the Felix I and II aquifers, with six wells installed as a sparge curtain down-gradient from the well field. Two 100-HP electric compressors supplied the air necessary for delivery to the groundwater system for air sparging actions. Groundwater samples were collected three times per year, at days 111, 222, and 333.

The Hoe Creek II and III systems operated as designed, with no major problems, during calendar year 2000. Ground water contaminant levels continued to be reduced, with only 5 of the 27 wells in the semiannual sampling network showing BTEX (benzene, toluene, ethyl benzene, and xylenes) contaminants. Total BTEX contaminant values ranged from 6 parts per billion (PPB) to 87 PPB. Offsite monitor wells showed no contaminant levels. The air sparge/bioremediation systems at Hoe Creek II and III are anticipated to continue operation for up to 5 years. Periodic shutdown periods to evaluate contaminant rebound levels in the ground water, as recommended by the Wyoming Department of Environmental Quality (WDEQ), will be conducted. Groundwater remediation must continue until water quality is returned to baseline conditions or to a class of use through "best practicable technology," as required by the WDEQ. 


\section{Hanna, Wyoming}

Experiments at the Hanna Underground Coal Gasification site were conducted in the 1970s, and the WDEQ has approved groundwater restoration for the site. Before the WDEQ releases and terminates the R\&D (license) permit, the site surface must be revegetated. In 1998, an evaluation of revegetation in the reclaimed permit areas indicated vegetation density, productivity, and species diversity are close to satisfying the WDEQ requirements for final release. During the annual inspection in 2000, the WDEQ determined that bond release and permit termination could be completed by 2002 .

The Rocky Mountain I Underground Coal Gasification site's experiments were conducted in the late 1980s, and the WDEQ has approved groundwater restoration for the site. Revegetation of the site is nearing completion and bond release is expected to occur in 2003. Activities in 2000 consisted of the Annual Inspection by the WDEQ, and spraying Canada Thistle to reduce the infestations of noxious weeds on the R\&D Permit area.

\subsection{Superfund Amendment and Reauthorization Act}

Title III of the Superfund Amendment and Reauthorization Act (SARA) of 1986 is known as the Emergency Planning and Community Right-to-Know Act (EPCRA). This act requires owners or operators of facilities that have certain hazardous chemicals on their site to provide information on the release, storage, and use of those chemicals to organizations responsible for emergency response planning. Executive Order 12856, signed by President Clinton on August 3, 1993, directs all federal agencies to comply with the requirements of EPCRA, including SARA 313 Toxic Release Inventory Program.

All EPCRA reporting requirements pertinent to NETL have been met at both the Morgantown and Pittsburgh sites. Table 2 identifies those requirements for which NETL has filed or will be required to report in the event of an occurrence.

Table 2. Emergency Planning and Community Right-to-Know Act Reporting

\begin{tabular}{|l|c|c|c|}
\hline \multicolumn{1}{|c|}{ Reporting Requirements } & Yes & No & $\begin{array}{c}\text { Not } \\
\text { Required }\end{array}$ \\
\hline EPCRA 302-303: Planning Notification & $\begin{array}{c}X \\
(P G H)\end{array}$ & $\begin{array}{c}X \\
(M G N)\end{array}$ \\
\hline EPCRA 304: EHS Release Notification & $X$ & & \\
\hline EPCRA 311-312: MSDS/Chemical Inventory & $X$ & & \\
\hline EPCRA 313: TRI Reporting & & & $X$ \\
\hline
\end{tabular}

Note: Because of differences in the hazards at each site, the EPCRA reporting requirements for Section 302 and 303 are not the same at the two sites.

Section 302 of EPCRA requires the owner or operator of any facility at which an extremely hazardous substance is present in amounts equal to or greater than specified threshold planning quantities to notify 
the State Emergency Response Commission (SERC) that the facility is subject to the emergency planning requirements. Section 303 of EPCRA requires the facility to designate a facility representative to participate in local emergency planning as a facility emergency response coordinator. The Pittsburgh site has previously notified the emergency response commission under Sections 302 and 303, and periodically updates emergency contact information with revised Section 311/312 submittals. Both NETL sites fall under the requirements of EPCRA 304, and in the event of a release are subject to the emergency notification requirements under Section 103(a) of the CERCLA of 1980. No releases required emergency notification during this 2000 reporting period.

SARA Title III requirements call for reporting all hazardous chemicals present at the facility during the preceding calendar year in amounts equal to or greater than 10,000 pounds, extremely hazardous substances at the facility in an amount greater than or equal to 500 pounds (or 55 gallons), or the Threshold Planning Quantity (TPQ), whichever is less. Table 3 lists those chemicals reported by NETL for 2000. Section 312 directs the owner or operator to prepare or have a material safety data sheet (MSDS) available for hazardous chemicals, and to submit an emergency and hazardous chemical inventory form by March 1 of each year, if the amount of the chemical equals or exceeds the TPQ. NETL maintains an active inventory of all hazardous materials on site along with the MSDS for each of these substances. The state and local emergency planning committees and local fire departments have been advised of all materials, quantities, and their location at the NETL sites. MSDS information on all materials has been made available.

Table 3. SARA Title III, Tier II Chemical Inventory Reporting List

\begin{tabular}{|c|c|c|l|l|}
\hline $\begin{array}{c}\text { Chemical } \\
\text { Name }\end{array}$ & $\begin{array}{c}\text { Quantity } \\
\text { (lb) }\end{array}$ & $\begin{array}{c}\text { TPQ } \\
\text { (lb) }\end{array}$ & \multicolumn{1}{|c|}{$\begin{array}{c}\text { Physical } \\
\text { Hazards }\end{array}$} & Health Hazards \\
\hline $\begin{array}{c}\text { Nitrogen } \\
\text { (MGN) }\end{array}$ & $10,000+$ & & Pressure & Acute \\
\hline $\begin{array}{c}\text { Hydrogen- } \\
\text { Sulfide } \\
\text { (MGN) }\end{array}$ & $<100$ & 500 & $\begin{array}{l}\text { Fire } \\
\text { Pressure } \\
\text { Reactivity }\end{array}$ & $\begin{array}{l}\text { Immediate (Acute) } \\
\text { Delayed (Chronic) }\end{array}$ \\
\hline $\begin{array}{c}\text { Coal } \\
\text { (MGN) }\end{array}$ & $10,000+$ & & Fire & Chronic \\
\hline $\begin{array}{c}\text { Alumina } \\
\text { (MGN) }\end{array}$ & $<10,000$ & & Fire & $\begin{array}{l}\text { Immediate (Acute) } \\
\text { Delayed (Chronic) }\end{array}$ \\
\hline $\begin{array}{c}\text { Sulfur Dioxide } \\
\text { (PGH) }\end{array}$ & 2,612 & 500 & Pressure & $\begin{array}{l}\text { Immediate (Acute) } \\
\text { Delayed (Chronic) }\end{array}$ \\
\hline
\end{tabular}

Submission of the Tier II Hazardous Chemical Inventory Form meets Section 312 requirements under the Pennsylvania Hazardous Material Emergency Planning and Response Act (Act 165). Section 313 of EPCRA, the Toxic Release Inventory (TRI) Reporting Program, requires the owner or operator of certain facilities that manufacture, process, or otherwise use listed toxic chemicals above threshold amounts to submit to EPA and designated State officials annual toxic chemical release inventory forms (Form R) for such toxic chemicals released into the environment. NETL did not exceed the threshold amounts for the listed toxic chemicals and thus was not required to submit a Form R. 


\subsection{Clean Air Act}

Air pollutant emissions are regulated under the Clean Air Act (CAA) as amended (42 USC 7401 through 7642). EPA's regulations are contained in 40 U.S. Code of Federal Regulations (CFR) 50 through 87.

West Virginia regulates ambient air quality through the West Virginia Department of Environmental Protection (WVDEP) Office of Air Quality. The West Virginia Air Pollution Control Regulations are in Title 45 WV Code; and Series 1-7a, 10, 11, 13-15, and 17-26.

Pennsylvania regulates ambient air quality at the Pittsburgh site through the Allegheny County Health Department's Bureau of Air Quality Control in Pittsburgh, Pennsylvania. The Pennsylvania Air Pollution Control Regulations are in 25 PA Code, Chapters 123, 127, 131, 135, and 139. The Allegheny County regulations are in the Air Pollution Control Article XXI.

NETL does not fall under the National Emission Standards for Hazardous Air Pollutants (NESHAP) for radionuclide emissions (40 CFR 61, Subpart H) at either the Pittsburgh (PGH) or the Morgantown (MGN) sites. Neither site reported any radionuclide dose equivalents in its 2000 annual report. Emissions at the sites do not appear to be significant, as shown in Table 4. Total air emissions decreased from 1999 to 2000 . There were no air quality permit exceedances or non-compliances during 2000.

Table 4. Estimated Air Emissions for 2000

\begin{tabular}{|l|c|c|}
\hline \multirow{2}{*}{\multicolumn{1}{c|}{ Pollutant }} & \multicolumn{1}{c|}{ MGN } & PGH \\
\cline { 2 - 3 } & \multicolumn{2}{c|}{ (tons per year) } \\
\hline Nitrous Oxides $\left(\mathrm{NO}_{\mathrm{X}}\right)$ & 8.82 & 0.86 \\
\hline Sulfur Dioxide $\left(\mathrm{SO}_{2}\right)$ & 0.037 & 4.06 \\
\hline Carbon Monoxide $(\mathrm{CO})$ & 3.02 & 0.45 \\
\hline $\begin{array}{l}\text { Volatile Organic } \\
\text { Compounds }(\mathrm{VOC})\end{array}$ & 0.17 & 0.25 \\
\hline Particulates & 0.67 & 0.89 \\
\hline
\end{tabular}

\section{Air Permits}

NETL held three air permits in effect during 2000, issued by the Allegheny County Health Department for the Pittsburgh site. One permit (number 7032056-000-00500) was for a 4,500,000 Btu/hr Cleaver Brooks Natural Gas Boiler, located in Building 922. The second permit (number 7032056-000-00501) was for three RayPak Finned Coppertube Boilers, in Building 922, each having a 1,630,000 Btu/hr input rating. Permit number 7023056-000-00800 was for the $500 \mathrm{lb} / \mathrm{hr}$ gas and coal-fired research unit located in Building 86. During 2000, administratively the site continued to be a synthetic minor source under CAA Title V. 
Air permits for the Pittsburgh site are obtained from the Allegheny County Health Department's Bureau of Air Quality Control in Pittsburgh, Pennsylvania. Allegheny County regulates the air program as outlined by EPA and Pennsylvania Department of Environmental Protection (PaDEP).

As part of Article XXI, and to comply with Title V of the 1990 Clean Air Act Amendments, NETL submitted an application for one new plant-wide permit for the Pittsburgh site. A comprehensive annual air emissions inventory was an integral part of the application. The site was notified that the application was accepted as administratively complete. NETL is currently awaiting the technical review of the application.

On May 1, 1995, the Morgantown site received air permit No. R13-1768 from the West Virginia Office of Air Quality (OAQ) and constructed an experimental syngas generator/hot gas desulfurization process development unit (PDU) at the site. NETL renewed the certificate annually to operate the syngas generator/PDU (Certificate 061 0064) from July 1 through June 30. An integrated shakedown of the syngas generator and PDU will occur in the spring and summer of 2001, followed by test program operations that will be used to develop gas cleanup technologies for advanced integrated coal gasification combined-cycle power generation systems. Operating summaries required by the PDU permit are submitted quarterly.

\section{Emission Source Inspections}

EPA requires all major air sources to be inspected annually to ensure compliance with existing site air permits. An inspection of the Pittsburgh site's air emission sources was conducted by the Allegheny County Health Department's Air Quality Program Division. Results of the inspection showed that the site was in compliance.

The Pittsburgh site maintained three 33-foot meteorological towers that monitored temperature, relative humidity, precipitation, and wind speed. Data were collected twice per week, and were used in the site's heating, ventilation, and air conditioning (HVAC) maintenance programs, emergency preparedness program, and air monitoring program.

In addition, the Pittsburgh site conducted a stratospheric ozone depletion program to recover and reclaim chlorofluorcarbons (CFC) from HVAC equipment. All CFC-containing equipment was inventoried, and measures are being taken to phase out these materials.

In Morgantown, site air emissions were inventoried quarterly to assess whether permit conditions were being met and if any additional permits or permit modifications were needed. Emissions were either measured, estimated by EPA methods, or projected by combustion and mass balance calculations. The 2000 air emissions inventory revealed that emissions were minor and were consistent with the estimations made the previous year. The site is a minor source of emissions, and no Title $\mathrm{V}$ permit is required.

Data from the 150-foot free-standing meteorological tower were used to report stormwater information. Additionally, the Emergency Operations Center used the data to predict the effects of accidental and non-routine releases. 


\subsection{Clean Water Act and the National Pollutant Discharge Elimination System}

Wastewater discharges are regulated under the Clean Water Act (CWA) (33 USC 1251 et seq.) and subsequent federal regulations (40 CFR Parts 121, 122, 125, 136, 405-471). Both West Virginia and Pennsylvania are National Pollutant Discharge Elimination System (NPDES)-authorized states. The West Virginia NPDES regulations are codified in Title 46-West Virginia Codes 1 and 2. The Pennsylvania NPDES regulations are codified in 25 Pennsylvania Code Chapters 16, 91-95, 97, 101, and 102.

In Pittsburgh, site wastewater placed into the sanitary sewer for subsequent treatment by the Pleasant Hills Authority (PHA) is regulated at the local level under the Pleasant Hills Industrial Sewer Use Permit Program. During 2000, domestic wastes were generated by approximately 1,000 employees representing three distinct federal agencies at the Bruceton Research Center. All sanitary waste from areas north of Wallace Road flows into the combined sanitary wastewater drainage systems tied into the Pleasant Hills, Pennsylvania municipal sewer system, a publicly owned treatment works (POTW). Sanitary waste south of Wallace Road is connected to the Clairton sewage treatment plant.

All treated laboratory and process wastewater from the Pittsburgh site flows to the nearby Pleasant Hills POTW, following pretreatment in the onsite wastewater treatment facility (WWTF). Wastewater is collected and treated at the WWTF before discharge. Treatment consists of oil recovery, followed by flow equalization with subsequent neutralization through the addition of caustic soda or ferric chloride. Metals and particulates are removed by agglomeration in the flocculation tank, coupled with solids separation in the plate separator and a filter press. An activated clay/activated carbon filtration unit was added in June 2000 to provide additional removal of organics and metals from the treated wastewater before discharge into the sanitary sewer. Subsequent monthly sampling/analyses of treated effluent indicated that only one discharge of regulated constituents (cyanide) occurred after installation of additional treatment units. The effluent can be recirculated if additional treatment is needed. The PHA agreed to accept the discharge. NETL submits monthly wastewater analysis data and submits an annual industrial waste survey report to PHA's consulting engineering firm, Ganett Fleming.

NETL was issued an Industrial Sewer Use Permit in December 1999 by the PHA as required by the Clean Water Act. The conditions placed on NETL by the permit limits the quantity of effluent constituents (free cyanide, phenolics, mercury, copper, chloroform, and $\mathrm{pH}$ ) that may be discharged in the wastewater stream.

NETL received two Notice of Enforcement Action Letters of Violation (NOV) from the Pleasant Hills Authority in 2000. These two NOVs stemmed from nine NETL Industrial Sewer Use Permit discharge limit violations. The first NOV was issued on February 17, 2000, addressing four violations at the shared subinterceptor location. Two of these violations occurred on January 4, 2000 for exceeding cyanide discharge limits at $0.010 \mathrm{mg} / \mathrm{L}$ (limit is $<0.010 \mathrm{mg} / \mathrm{L}$ ), and mercury at $0.0023 \mathrm{mg} / \mathrm{L}$ (limit is $<0.0004$ $\mathrm{mg} / \mathrm{L}$ ). The remaining violations occurred on January 5 and 7, 2000, for exceeding discharge limits for mercury at $0.0005 \mathrm{mg} / \mathrm{L}$ and $0.0011 \mathrm{mg} / \mathrm{L}$, respectively. NETL shares this discharge location with two other federal agencies, the National Institute for Occupational Safety and Health (NIOSH), and the U.S. Department of Labor Mine Safety and Health Administration. Additional sampling at this shared 
subinterceptor location revealed that the NETL-generated waste stream was not the source of these violations. Consequently, NETL was removed from the subinterceptor sampling stream beginning in 2001.

The second NOV was issued on April 27, 2000, addressing five violations at the NETL Wastewater Pretreatment Facility in Pittsburgh. One of these violations occurred on January 26, 2000 for exceeding discharge limits for mercury at $0.0003 \mathrm{mg} / \mathrm{L}$ (limit is $0.0002 \mathrm{mg} / \mathrm{L}$ ). Three violations occurred on February 23, 2000 for exceeding discharge limits for cyanide at $0.007 \mathrm{mg} / \mathrm{L}$ (limit is $<0.005 \mathrm{mg} / \mathrm{L}$ ), mercury at $0.0006 \mathrm{mg} / \mathrm{L}$, and copper at $0.12 \mathrm{mg} / \mathrm{L}$ (limit is $0.08 \mathrm{mg} / \mathrm{L}$ ). The remaining violation occurred on March 27, 2000 for exceeding discharge limits for cyanide at $0.005 \mathrm{mg} / \mathrm{L}$.

NETL implemented a program to transfer the Building 141 laboratory wastewater from the lab waste holding tank to the WWTF. This will permit greater control over the quality of the treated effluent, especially in view of the installation of the additional filtration system. The analytical reports will continue to be submitted to the PHA's consulting engineering firm.

The Pittsburgh site received an NPDES Storm Water Permit, No. PA0025844, in June of 1996. The Pittsburgh site is required to monitor and report the results of two outfalls quarterly. Outfall 001 parameters are flow, suspended solids, $\mathrm{CBOD}_{5}$, oil and grease, aluminum, iron, manganese, lead, mercury, $\mathrm{pH}$, and ammonia. Outfall 002 parameters are flow, suspended solids, aluminum, iron, manganese, lead, $\mathrm{pH}$, and ammonia.

At Morgantown, NETL retained two (2) permits under the NPDES during 2000. All monitored parameters were within permit limitations during 2000. One permit (Morgantown Utility Board [MUB] Permit No. 012), was issued by the MUB for the discharge of sanitary and pretreated industrial wastewater to the City of Morgantown's municipal sewer system POTW. This permit was renewed in June 2000. The other Morgantown permit issued under the NPDES was WV/NPDES Permit No. WV0111457, General Permit Registration No. WVG610042, issued by the West Virginia Department of Commerce, Labor and Environmental Resources Division of Environmental Protection, for the discharge of stormwater to Burroughs Run and West Run. As stated in the WV/NPDES permit approval letter, NETL is required under the terms and conditions of this permit to:

1. Monitor and report semiannually to the State of West Virginia from outfalls 002,005 , and 010.

2. Maintain a stormwater pollution prevention plan and a groundwater protection plan. These plans are to be retained on site and made available for review by the state at their request.

\subsection{Resource Conservation and Recovery Act}

The RCRA (42 U.S. Code 6901 et seq.) regulates the generation and management of solid wastes at the federal level, including those designated as hazardous. EPA's hazardous waste regulations are codified in Title 40 CFR Parts 260-271. The WVDEP, in conjunction with the EPA, performed an external audit in November 2000 at the Morgantown site. No notices of violations were awarded by 
either party.

NETL complied with all regulations, by carefully and diligently removing hazardous waste in a timely manner at both sites. The total for RCRA Hazardous Waste was 146.5 cubic feet in Pittsburgh and 151 cubic feet in Morgantown.

Table 5 shows the status of aboveground regulated storage tanks at both Pittsburgh and Morgantown.

Table 5. Aboveground Storage Tanks

\begin{tabular}{|c|c|c|c|c|}
\hline Location & Description & $\begin{array}{c}\text { Capacity } \\
\text { (U.S. Gallons) }\end{array}$ & $\begin{array}{l}\text { Active or } \\
\text { Inactive }\end{array}$ & Comments \\
\hline NETL-PGH & Waste Oil Holding Tank & 950 & Inactive & $\begin{array}{l}\text { Taken out of service in } \\
1992 .\end{array}$ \\
\hline NETL-PGH & Caustic Soda Tank & 1,500 & Active & \\
\hline NETL-PGH & Ferric Chloride Tank & 1,500 & Active & \\
\hline NETL-PGH & Heating Oil Tank & 2,200 & Inactive & $\begin{array}{l}\text { Taken out of service in } \\
1990 .\end{array}$ \\
\hline $\begin{array}{l}\text { NETL-MGN } \\
\text { Outside B13 }\end{array}$ & $\begin{array}{l}\text { Diesel Fuel Storage } \\
\text { (Double Tank) }\end{array}$ & 50 & Active & $\begin{array}{l}\text { Used for research } \\
\text { equipment. }\end{array}$ \\
\hline $\begin{array}{l}\text { NETL-MGN } \\
\text { Outside B29 }\end{array}$ & $\begin{array}{l}\text { Diesel Fuel Storage } \\
\text { (Double Tank, Bermed) }\end{array}$ & 250 & Active & Vehicle fuel. \\
\hline $\begin{array}{l}\text { NETL-MGN } \\
\text { Outside B29 }\end{array}$ & $\begin{array}{l}\text { Gasoline Fuel Storage } \\
\text { (Double Tank, Bermed) }\end{array}$ & 500 & Active & Vehicle fuel. \\
\hline $\begin{array}{l}\text { NETL-MGN } \\
\text { Outside B34 }\end{array}$ & $\begin{array}{l}\text { Diesel Fuel Storage } \\
\text { (Double tank) }\end{array}$ & 50 & Active & $\begin{array}{l}\text { Emergency generator } \\
\text { fuel. }\end{array}$ \\
\hline $\begin{array}{l}\text { NETL-MGN } \\
\text { Outside Navy } \\
\text { Facility }\end{array}$ & $\begin{array}{l}\text { Diesel Fuel Storage } \\
\text { (Double Tank) }\end{array}$ & 1,000 & Active & $\begin{array}{l}\text { Emergency generator } \\
\text { fuel. }\end{array}$ \\
\hline
\end{tabular}

\subsection{Safe Drinking Water Act}

Drinking water requirements are codified under the Safe Drinking Water Act (SDWA) (42 USC 300f through 330j - 11), and regulated in 40 CFR Parts 141 through 143. NETL is classified as a nontransient, non-community water system under these laws and regulations. Because NETL does not provide treatment or storage of this water, the monitoring requirements of a public water supplier are not required; however, both sites conducted sampling and analysis programs at selected potable water locations and compared samples against the SDWA primary and secondary regulatory standards.

The Morgantown site receives its potable water supply from the city of Morgantown. Samples were taken periodically from potable water locations and tested. No samples met or exceeded SDWA limits in 2000 . 
The Pittsburgh site receives its water supply from the Pennsylvania American Water Company. Twentyseven primary and secondary drinking water contaminants were sampled at nine representative locations in 2000. In addition, 44 water coolers were sampled for concentrations of lead, copper, and $\mathrm{pH}$. All of the results of the sampling were below the maximum contaminant levels, so no corrective actions were taken.

\subsection{Toxic Substances Control Act}

Requirements for managing polychlorinated biphenyls (PCBs), asbestos, and lead are codified in Toxic Substances Control Act (TSCA) 15 USC 2601 to 2654. EPA regulations addressing PCBs and asbestos in conjunction with the TSCA are codified in 40 CFR 761 and 763, respectively. Asbestos is also regulated under CAA (40 CFR 61, Subpart M); U.S. Occupational Safety and Health Administration (OSHA) (29 CFR 1926.1101); and Pennsylvania's Allegheny County Health Department (ACHD) Article XXI.

At the Pittsburgh site, Buildings 900 and 911 were declared "asbestos free" by the DOE Industrial Hygienist based upon bulk sampling and/or inspection results. NETL typically initiates an abatement action for four reasons: decommissioning/demolition operations; remodeling/reconstruction operations; asbestos floor tile concerns; and providing an "asbestos free" work place. Both the Asbestos Abatement/Removal Contractor $(\mathrm{AA} / \mathrm{RC})$ and the independent third party industrial hygiene monitoring companies were registered with the ACHD. All AA/RC employees were trained and licensed by both ACHD and the Pennsylvania Department of Labor and Industry. All asbestos abatement actions were performed under a permit issued by the ACHD. Four permits were issued by the ACHD in 2000. All asbestos containing waste was disposed in an EPA approved landfill. Thirty-four cubic yards of asbestos waste were removed from NETL in 2000.

All PCB containing transformers were either removed from the site or flushed to remove the PCB's and refilled with a non-PCB fluid. All fluorescent lamp ballasts were presumed to contain PCB's and were properly disposed in an EPA approved landfill.

Lead paint sand blasting was performed under full containment, in accordance with an ACHD permit. The waste was disposed in an EPA-approved landfill. Small amounts of lead paint were removed with caustic paint remover. The waste was disposed in an EPA-regulated landfill. Steel structure with lead paint was disposed at a smelter, which captured the lead paint fumes in an EPA approved baghouse.

At Morgantown, all abatement of asbestos and asbestos-containing materials (ACM) was conducted by West Virginia licensed asbestos abatement contractors. All abated asbestos and ACMs were properly disposed in asbestos-approved landfills.

A full asbestos survey of all Morgantown site facilities was completed during 1992. No known friable asbestos remains on the Morgantown site. The current management plan for asbestos at NETLMorgantown is to manage in place; abating asbestos and ACM only when it becomes necessary because of construction, renovation, or maintenance. Facility plans and work orders are reviewed during the planning stages for asbestos disturbance. Known ACM is labeled. 
As part of a renovation project in building 3 on the Morgantown site, tile mastic containing asbestos was abated from approximately 1000 square feet of floor. The abatement was conducted by a WV licensed abatement contractor. Various small asbestos abatement activities were completed throughout the year at various locations on site, primarily drilling holes through asbestos-content solid wall panels for new conduit or pipe runs.

All PCB transformers were removed from the Morgantown site during previous years.

A survey of lead-based paint at the Morgantown site was completed in early 1997. A priority list was made for lead paint removal projects, based on conditions of paint and proximity to workers. Lead paint has been abated on all fire extinguishers and other outdoor fire apparatus. A multi-year lead paint abatement plan for the site's pipe bridge supports has continued; 40 supports were abated this year. A WV-licensed contractor did the abatement, and lead paint debris was disposed by the site support contractor hazardous waste personnel at an approved landfill.

\subsection{Federal Insecticide, Fungicide, and Rodenticide Act}

Pesticide requirements are codified under the Federal Insecticide, Fungicide, and Rodenticide Act (FIFRA) 7 USCS $\S \$ 136$, et seq. EPA pesticide regulations are documented in 40 CFR, Parts 162, 166 , and 171.

Policy and procedures regarding the use of insecticides, fungicides, and rodenticides at Morgantown were contained in NETL-MGN Order 5400.1, General Environmental Protection Program of June 3, 1993. Pest control for buildings at the Morgantown site was performed monthly or as needed, and entailed spraying interior baseboards and corners. No FIFRA-regulated materials were stored onsite. The use of pesticides at the Morgantown site was limited to materials that are not classified by the EPA for restricted use. Compliance was verified by comparing the MSDS for the onsite material with the applicable standard. Pesticides were applied by qualified contractors using certified personnel. The only site personnel who applied pesticides were maintenance technicians. They occasionally used overthe-counter sprays on nests built in or on outside equipment; MSDS are obtained and kept for these sprays.

An integrated pest management program was implemented at the Pittsburgh site to comply with federal, state, and local pest management requirements. All pesticide/herbicide applicators were trained and licensed by the PaDEP. All pesticide and herbicide MSDS and all technical specification sheets were submitted to the site's Chemical Hygiene Officer for review and approval prior to use. No pesticides or herbicides were stored onsite. The applicator brought only the minimum quantity necessary for that day's work. Because there was no waste, there was no need to store the materials.

Pest control for buildings at the Pittsburgh site was limited to "banding" (dispersing crystals on grassy surrounds of buildings and foundation spraying). Any indoor applications were performed on an asneeded basis, as were pesticide and herbicide applications for grounds maintenance purposes. The Pittsburgh cafeteria was treated monthly with a "crack and crevice control" technique. A hand-pumped, atomizing spray tank-wand treated baseboards, door thresholds, and through-wall water pipes. 


\subsection{National Environmental Policy Act}

The National Environmental Policy Act of 1969 (NEPA) 42 U.S.C. 4321 et seq. established Federal policy for protecting environmental quality. Under this policy, an Environmental Impact Statement (EIS) must be prepared to evaluate the environmental consequences of any major federal action that might have significant impact on the quality of the human environment. A Record of Decision would be prepared to document the federal decision on a course of action following an EIS review. If the need for an EIS is not clear (for example, if a proposed action has uncertain potential for environmental impacts but does not meet DOE's criteria for preparation of an EIS), an Environmental Assessment (EA) would be prepared. After preparing an EA, either a decision would be made to prepare an EIS or a Finding of No Significant Impact (FONSI) would be issued if an EIS was determined to be unnecessary.

Certain classes of actions that do not significantly affect the environment, either individually or cumulatively, can be categorically excluded from more in-depth NEPA review (i.e., preparation of either an EIS or EA). DOE's NEPA implementing procedures (10 CFR 1021) identify those categories of excluded actions and the eligibility criteria for their application.

\section{Performance}

NETL conducted NEPA reviews for proposed onsite actions and offsite federal actions, which were planned in cooperation with other governmental organizations, educational institutions, or private industry. During calendar year 2000, a total of 224 NEPA reviews resulted in categorical exclusions. All new onsite activities were covered by categorical exclusions.

During 2000, an Environmental Assessment (DOE/EA-1331) was completed and FONSI was issued for a proposed Remediation of Subsurface and Groundwater Contamination at the Rock Springs In-Situ Oil Shale Retort Site, Rock Springs, Wyoming.

Preparation of an EA (DOE/EA-1309) continued for a project that examines the co-utilization of coal with E-Fuel ${ }^{\mathrm{TM}}$ from the SlurryCarb ${ }^{\mathrm{TM}}$ process. E-Fuel ${ }^{\mathrm{TM}}$ is a product from heat treatment of organic wastes, particularly wastes containing high concentrations of oxygen. In this project, coal would be combusted with fuel produced from processing municipal sewage sludge.

During 2000, decisions were made to prepare EAs for the following off-site projects:

COcean Sequestration of $\mathrm{CO}_{2}$ Field Experiment (DOE/EA-1336). This proposed action involves a series of 2-hour controlled releases of liquid carbon dioxide at an 800-meter depth off the Island of Hawaii, for studying the dispersion and dissolution characteristics of $\mathrm{CO}_{2}$ in seawater. Preparation of a draft EA and public participation were completed during 2000.

CDemonstration of a Black Liquor Gasification System (DOE/EA-1347). This proposed action would involve construction of a commercial size-facility to demonstrate the potential benefits of using gasification technology in pulp and paper mills. Under this action, existing smelters used for chemical recovery at a Big Island, Virginia, paper mill would be replaced with a steamreformer gasification system. A draft EA was released in August 2000, public participation 
was completed, and a final EA was distributed. A FONSI was also issued.

CDemonstration of a Coking Reactor Module (DOE/EA-1337). This proposed action would involve the construction of a novel coke-making reactor system based on technology developed by Calderon Energy Company. The system was proposed for a steel plant near Cleveland, Ohio.

A final EIS (DOE/EIS-0289) was released in June 2000 for the JEA Circulating Fluidized-Bed Combustor Project at Jacksonville, Florida. In November, following additional consultation and discussions with the National Marine Fisheries Service and the Marine Mammal Commission, a mitigated Record of Decision was issued.

During 2000, a decision was made to prepare an EIS for the following off-site project:

CKentucky Pioneer Integrated Gasification Combined Cycle Demonstration Project (DOE/EIS-0318). This proposed project would involve construction of a 540-megawatt power plant in Clark County, Kentucky, using a fuel blend of coal and refuse-derived pellets.

The following three EIS preparation efforts continued in 2000:

CLow Emission Boiler System Proof-of-Concept Project (DOE/EIS-0284) at Elkhart, Illinois.

CClean Power from Integrated Coal/Ore Reduction (CPICOR) (DOE/EIS-0280) at Vineyard, Utah.

CMcIntosh Unit 4 Pressurized Circulating Fluidized-Bed Demonstration Project (DOE/EIS0282) at Lakeland, Florida.

\subsection{Federal Facility Compliance Act}

The Federal Facility Compliance Act (FFCA) is an amendment to RCRA, initiated as a result of States protesting the protection of federal facilities from fines or penalties. The congressional intent was to waive the sovereign immunity of federal agencies and require them to comply with the full range of enforcement tools available to all regulatory authorities. Under the FFCA, there is explicit authority to issue administrative compliance orders that are RCRA violations. Additionally, the FFCA requires the EPA to conduct annual inspections of federal facilities with RCRA Part B permits.

FFCA also encourages federal facilities to seek voluntary resolution to environmental challenges. NETL sites are not currently under onsite consent agreements and are not RCRA Part B facilities. However, both sites conduct their environmental programs according to applicable federal, state, and local regulations. 


\subsection{Other Environmental Statutes}

The Pittsburgh site completed an ecological baseline risk assessment in June 1998. Based on the sitespecific and regional ecology, several ecological receptors are potentially at risk from contaminants at the sites. Contaminants were detected in the surface water, sediment, soil and groundwater in Pittsburgh. Potential receptors of contaminants in surface water and sediment include fish, benthic macroinvertebrates, other aquatic flora and fauna, and some terrestrial faunal species. Potential receptors of contaminants in soils include deer, rabbits, foxes, raccoons, birds and terrestrial flora (e.g., Scotch Pine trees, Black Locust trees, and Oak trees) and fauna.

An extensive, site-wide monitoring and risk assessment effort was conducted at the Morgantown site in 1995. The purpose was to investigate all known potential risk sources, including abandoned ponds, removed underground tanks, material storage areas. From this effort, a few small scale remediations were performed in order to reduce risks to human and ecological receptors to acceptable levels.

Wetlands, benthic macroinvertebrate, fisheries, herptofauna, avifauna, small mammals, terrestrial vegetation, and threatened and endangered species surveys of the Morgantown site were conducted in late summer 1992. The cultural resources investigation was conducted in fall 1992. A review of pertinent regulations, technical reports, and documents related to the Morgantown site was conducted to characterize the remainder of resources at the Morgantown site. Climate, air quality, geology, sediment, stormwater, land use, and human health and safety data were obtained from studies conducted in 1990, 1991, 1992, and 1993.

\subsubsection{Endangered Species Act}

The following steps were taking to ensure NETL is in compliance with the Endangered Species Act (ESA). The following agencies were contacted for information regarding threatened and endangered species on and adjacent to the Morgantown site:

\section{CNatural Heritage Program of the West Virginia Division of Natural Resources (WVDNR) CU.S. Fish and Wildlife Service \\ CWest Virginia University \\ CMarshall University Department of Biological Sciences}

The U.S. Fish and Wildlife Service-West Virginia Field Office, the WVDNR Natural Heritage Program, and other sources listing critical habitat characteristics were consulted. Information obtained from these sources indicated that there is no documentation of rare, threatened, or endangered species in the vicinity of the NETL site in Morgantown, West Virginia. Additionally, the WVDNR Wildlife Resources Section knew of no rare species surveys conducted in the Morgantown facility area. The survey and delineation of threatened and endangered species habitats near the Morgantown facility was to be conducted, if these species were suspected of inhabiting the Morgantown site. Optimal habitat survey periods would encompass the normal growing season (i.e., May through September). Pursuant to the information received from the agencies contacted, it was determined that no threatened and endangered species inhabited the site. 
The following agencies were contacted for information regarding threatened and endangered species on and adjacent to the Pittsburgh site:

CPennsylvania Department of Environmental Protection

CU.S. Fish and Wildlife Service

CPennsylvania Game Commission

CPennsylvania Fish and Boat Commission.

The United States Fish and Wildlife Service (FWS) maintains a list of federal endangered and threatened species of animals. The FWS responded on December 14, 1994 that, except transient species, no federally listed or proposed threatened or endangered species under FWS jurisdiction are known to exist at the Pittsburgh site.

The Pennsylvania Fish and Boat Commission, Bureau of Fisheries and Engineering (PFBC) was contacted for information on Pennsylvania's state endangered and threatened species of fish, amphibians and reptiles. The PFBC responded in a letter dated December 6, 1994 that none of the fishes, amphibians, or reptiles the PFBC lists as endangered or threatened are known to occur at or in the immediate vicinity of the NETL Pittsburgh site.

The Pennsylvania Game Commission, Bureau of Wildlife Management, (PGC) has jurisdiction over wildlife and wildlife habitats in Pennsylvania. The PGC responded via letter dated December 7, 1994, that except for transient species, no state listed threatened or endangered species under PGC jurisdiction are known to exist at the NETL Pittsburgh site.

The Pennsylvania Natural Diversity Inventory (PNDI) is maintained by the PaDEP, Bureau of Forestry, with technical assistance from the Nature Conservancy and the Western Pennsylvania Conservancy. The PNDI contains information on rare, endangered, and threatened animals and plants; exemplary natural communities and special geologic features; and other natural features of Pennsylvania. No response has been received from this agency to date. However, a previous response from 1992 indicated that no confirmed resources of special concern were identified within the study area.

In addition to the agency correspondence, no threatened or endangered species were identified at the NETL Pittsburgh site during a terrestrial and aquatic ecological study conducted in 1981. Pursuant to the information received from those agencies contacted, it was determined that no threatened and endangered species were suspected of inhabiting the site.

\subsubsection{National Historic Preservation Act}

The National Historic Preservation Act is not applicable. NETL has evaluated all potential landmarks at both sites and determined that there are no historically significant landmarks that require preservation.

\subsubsection{Migratory Bird Treaty Act}

The Migratory Bird Treat Act is not applicable. NETL did not take any actions in 2000 that had, or was likely to have, a measurable negative effect on migratory bird populations. No migratory birds of 
any species were intentionally taken during the conduct of any program, activity or action, including but not limited to banding, marking, scientific collection, taxidermy, and depredation control.

\subsection{Executive Orders}

\subsubsection{E.O. 13148 -- "Greening the Government Through Leadership in Environmental Management"}

[Note: Please see section 2.2 of this report "Superfund Amendments and Reauthorization Act" for information on EPCRA as required by E.O. 13148].

Towards the end of 2000, NETL solicited presentations from the two program support contractors about their ability to assist NETL in implementing an appropriate Environmental Management System (EMS). Following these presentations, plans were made to hire a consultant to perform an environmental management system assessment (also called an initial environmental review), as referenced in ISO 14004. The objective of the review will be to determine the degree to which NETL's existing integrated safety management system (ISMS), safety analysis review system (SARS), and environmental management programs conform with the ISO 14001 EMS Standard and the EPA's Code of Environmental Management Principles.

\subsubsection{E.O. 11988 "Floodplain Management"}

Floodplain management is not applicable. The NETL sites did not conduct any actions impacting floodplain management in 2000.

\subsubsection{E.O. 11990 "Protection of Wetlands"}

Protection of Wetlands is not applicable. The NETL sites did not conduct any actions impacting wetlands in 2000. 


\section{Environmental Program Information}

\subsection{Introduction}

The following is a brief description of the major environmental programs at NETL, including site meteorology, monitoring and surveillance, environmental restoration and waste management, and effluent monitoring.

Additionally, information on significant environmental activities at NETL not adequately covered in other sections is presented here. This includes the directives program, environmental occurrences, facility environmental performance measures, environmental training programs, and pollution prevention and waste minimization programs. There is also a discussion of NETL's initiatives pursuant to the Clean Water Action Plan, including efforts to improve water quality through collaborative approaches to watershed protection administered through the States, local governments, industry, other federal agencies, and interested stakeholders. Information presented in the Compliance Summary and other sections of this report are not discussed here.

\subsection{Site Meteorology}

Meteorological data for the Morgantown site was collected via a 150-foot free-standing meteorological tower. Data collection points are at ground level, and above ground at 33 feet, 75 feet, and at 150 feet. The data collected at ground level were air temperature, relative humidity, and total rainfall. The other stations monitor wind direction, wind speed, and air temperature. All data collected is stored on a computer, located in building 33 of the Morgantown site.

Meteorological data for the Pittsburgh site was collected via three separate 33-foot free-standing meteorological towers. Data collection points were at ground level, and above ground at 6 feet and 33 feet. The data collected at ground level was rainfall. Relative humidity, air temperature and solar radiation were collected at the 6-foot levels. Air temperature, vertical and horizontal wind speed, and wind direction were collected at the 33-foot increment. Data collected is stored on computers, located in Pittsburgh's building 922 and $\mathrm{PM}_{2.5}$ trailer.

Meteorological data at both sites was used in modeling for emissions and emergency response. Data was also used in a project management Power and Environmental Systems experimental $\mathrm{PM}_{2.5}$ study.

\subsection{Site Monitoring and Surveillance}

The sites currently monitor groundwater, stormwater, industrial wastewater, drinking water, meteorological conditions, and air emissions (based on the scope of the research project) independently. Analyses from several groundwater monitoring wells were supplied to the State as information only, and are not the result of any consent agreement or permit requirement. A detailed discussion of groundwater 
monitoring is presented in Section 7.0. NETL monitored its local site outfalls as specified by the requirements of the NPDES permits, and its industrial wastewater discharges to the local POTW (Pittsburgh) in accordance with its permit. Both sites received "generator only" status, which means that the sites may accumulate onsite hazardous wastes for no longer than 90 days. The Pittsburgh site filed a modified Notification of Hazardous Waste Activity to inform the state that the site will perform elementary neutralization of waste laboratory acids and caustics in the wastewater treatment facility. Otherwise, no hazardous waste was treated, stored, or disposed at either site.

\subsection{Effluent Monitoring}

The Pittsburgh site performed monthly sampling/analyses on the laboratory and process-related wastewater generated on the R\&D plateau, and placed into the sanitary sewer for subsequent treatment by the Pleasant Hills Authority sewage treatment plant. The laboratory and process water generated in the coal-preparation building (building 141) was collected in the laboratory waste holding tank for flow equalization and neutralization and was pumped into a tank. It was then transported to the WWTF for additional treatment before discharge. The results of the monthly sampling and analysis were sent to the PHA consulting engineering firm.

The Morgantown site monitored its industrial wastewater effluent and its storm water discharge effluent. Industrial wastewater included non-contact cooling water, non-contact process cooling water overflow, boiler blowdown, laboratory sink, laboratory floor drains, and motor pool wastewater. Storm water was composed of rain water run-off from buildings, parking lots, developed and undeveloped area. Monitoring results can be found in Sections 6.1 and 6.2.

\subsection{Other Environmental Issues and Actions}

\subsubsection{Directives Program}

The directives process used total quality management principles to identify and implement standards that adequately protect workers, the public, and the environment. The starting point was a clear plan for the work to be performed (such as construction, operation, research, or remediation). A team analyzed the work plan to determine potential hazards and identify ways to remove or control those hazards. In addition to this team's analysis, input and suggestions were sought from stakeholders, including members of the public, employees, and union representatives regarding concerns or hazards that must be addressed and approaches for ensuring adequate environmental protection. The primary objective of the process was to identify or develop a set of directives that, when implemented, provides reasonable assurance that the health and safety of the workers, public, and the environment will be protected during the performance of the work.

In 1996, NETL identified hazards at both the Pittsburgh and Morgantown sites through distribution of standard forms listing a wide range of possible hazards. Each division or operation was asked to identify possible hazards in their workplace, and to return the completed forms. The results were used to establish control requirements for all waste activities. 
In 2000, the risks associated with the hazard identification process were addressed through the development and implementation of a comprehensive set of environment, safety, and health (ES\&H) directives at NETL. Although this process is not expected to be completed until 2001, final directives for ISM, ES\&H reporting, ES\&H requirements for offsite contractors, R\&D SARS, life safety design criteria, and work control were completed during 2000. The development of many other directives was initiated and reviewed during 2000 -- a complete cycle from inception to final approval that often takes over a year to complete. Directives receive a rigorous internal review by all internal stakeholders prior to final approval by senior management.

\subsubsection{Environmental Occurrences}

Notification of environmental occurrences is required under a number of Federal, state, and local environmental statutes and regulations. DOE (Headquarters) requires notification of all environmental occurrences. NETL Procedure 151.1-2, Occurrence Categorization and Reporting, implements these DOE reporting requirements and complies with state and local statutes.

DOE Order 232.1A provides guidelines on categorizing and reporting environmental occurrences to DOE. The order divides occurrences into three categories: emergencies, unusual occurrences, and off-normal occurrences. At both sites, an onsite emergency response organization (ERO) was in place and responded 24-hours a day. The ERO cleaned up or mitigated small spills. If larger spills occurred, offsite assistance was used as needed. Once an incident occurred, the ERO was responsible for categorizing the incident, notifying the proper regulatory agencies, and completing the DOE occurrence reporting.

NETL reported nine occurrences during 2000. Three occurrences were not environmental in nature (a power outage, employee injury, and lockout/tagout violation) and are not described here. Another occurrence, while not environmental in nature, was so significant to our operations that it is described in section 3.5.3. The five environmental occurrences are also described in detail.

A wastewater discharge exceedence took place in February 24, 2000. A NOV from the Pleasant Hills Authority (Pennsylvania) for exceeding wastewater discharge limits was received. The NOV alleged four separate exceedences of allowable concentrations of mercury and free cyanide. The discharge from this wastewater is covered by the NETL Industrial Sewer Use Permit. It was not established that NETL is responsible for the entry of these contaminants into the wastewater system, which is shared with another federal facility (NIOSH).

A meeting was conducted on May 26, 2000, between NETL, the EPA, and the Pleasant Hills Authority to resolve the outstanding issues regarding the validity of the Notice of Violation. The non-compliance issues, which included recognition by the Pleasant Hills Authority that NETL was not the source of contamination at this sampling location, were resolved. Beginning in the year 2001, NETL will no longer be required to sample at this location because there is no record of any industrial discharge ever being attributed to NETL.

A water quality violation took place on May 02, 2000. Pleasant Hills Authority issued NETL a Notice of Enforcement Action Letter of Violation based on findings made on the quality of the wastewater 
discharge. The discharge limits are established in Section V - Discharge Permit Requirements of the Industrial Sewer Use Permit. The NOV noted that NETL had not signed the Industrial Sewer Use Permit, had failed to pay fines of Letter of Violation Dated February 17, 2000, and had failed to meet local limits for wastewater discharge on five occasions.

To mitigate further occurrences, NETL completed several physical modifications aimed at improving the quality of the wastewater discharge. The sampling procedure used to measure free cyanide was examined to ensure that the exceedence was not the result of an erroneous sampling technique.

An accidental release of fire suppression foam occurred on June 05, 2000. Two representatives from a subcontractor, Grinnell, conducted a test of the foam fire suppression system in building 64 at the Pittsburgh site. As part of the test, excess foam was to be released onto the grass to avoid storm sewer contamination. The system outlet hose was secured. The pressure and amount of foam flowing through the hose caused the hose to reorient so that it faced upright and approximately 10 gallons were released. The resulting suppression foam became airborne, spraying material onto buildings 64 and 92, and the south end of substation 6. The foam also struck the asphalt pavement between building 92 and substation 6. Some diluted foam entered Lick Run Creek by way of the Bruceton Research Center North Outfall. No foam was ever observed in the North Outfall. The PaDEP, Bureau of Water Quality Management required DOE to file a written incident report.

Monitoring of the discharge outfalls began immediately to determine if there was any damage to the environment. None was detected.

It was determined that the subcontractor tasked with the preventing the fire suppression foam from entering into the North Outfall storm water discharge system failed to execute proper procedures. As a result, there was an accidental release of material into a regulated NPDES point discharge system. The NPDES enforcement authority and the PaDEP were notified, and a follow- up incident report was written and sent to PaDEP .

An outfall discharge occurred on September 05, 2000. A member of the public observed the flow of a white foamy substance and a small amount of a floating red liquid, similar in appearance to automatic transmission fluid. This was reported to the local township, which notified an NETL representative. An investigation into the nature of the material in the outfall followed, and cleanup of the material began immediately. Oil adsorbent booms were placed across the south outfall drainage pathway to soak up the floating residual material. This prevented additional impact on Lick Run creek. Subsequent observation of the south outfall (12-36 hours later) indicated no additional residual red liquid flow. Absorbent booms were then removed.

The residual red liquid is suspected to have originated from an offsite source. Examination of all catch basins onsite gave no evidence that any were impacted by entrance of polluting materials. Foaming at the outfall is the result of historic discharge of acid mine drainage flowing into storm sewers from hillsides south of 900 Plateau.

The reporting of this incident is required by the site NPDES permit. The action by NETL to contain and to report this incident reflects a site policy to be proactive in the protection of the environment. 
A ferric chloride release into secondary containment occurred on December 04, 2000. Approximately 300 gallons of a ferric chloride solution was initially released from the primary containment vessel and into the designed secondary containment system. This triggered a report to the PaDEP. No material was released into the environment.

The area was immediately secured to prevent unauthorized entry, and the solution was transferred from the secondary containment into recovery drums. Installation of the holding tank for the ferric chloride included a plastic lined steel valve. There was apparent leakage between the plastic valve liner and the steel valve body. This permitted small amounts of ferric chloride to attack the steel resulting in degradation of the flat flange mating surfaces. This ultimately caused the valve attachment flange to leak resulting in the release of the contents of the tank into the secondary containment system.

The replacement of the original ferric chloride storage/delivery system with compatible Department of Transportation (DOT)-specified 55-gallon plastic drums and associated plastic piping/valving system was sufficient to prevent recurrence. No airborne emissions were detected and there were no adverse health-related impacts.

\subsubsection{Other Occurrences}

A trailer fire occurred in Morgantown on October 10, 2000. The trailer was occupied by site support contractors, who were evacuated immediately without injury. The local fire department was called to the scene, and the fire was extinguished within minutes of their arrival. Fifteen permanent employees in the trailer were relocated to alternative work areas. Records and materials damaged by smoke and heat were sent out for restoration. No significant, long-term, programmatic impacts resulted from this incident.

The fire was accidental. The ignition source was determined to be in the power feed to a recently installed dimmer switch. While the direct cause cannot be determined, it appears most probable that a short was caused by damage to the wire insulation, occurring when the original dimmer switch was installed sometime between 1990 and 1992, or when the switch was replaced on August 25, 2000. A secondary ignition source was a paper vapor backing on the installed fiberglass insulation. The fire was not detected quickly because the location was behind the walls and crept to the space above the suspended ceiling. Smoke detectors were located beneath this attic space. DOE/NETL, the Morgantown Fire Department, the contractor, and an experienced accident investigator from EG\&G's Lawrence Livermore operations all participated in conducting the fire investigation and provided a very comprehensive analysis of the potential causes.

\subsubsection{Environmental Performance Measures}

Throughout 2000, a formalized approach to performance measurement was employed as part of an effort to address performance requirements, such as those mandated by the Government Performance and Results Act. This approach included measurement elements covering management of ES\&H risks associated with implementing organizational missions. Goals and objectives for ES\&H activities were established and specific performance targets addressing ES\&H risks were included for measurement. 
Refinements of ES\&H strategies and specific targets to meet the goals and objectives for 2000 were made, based on performance results from 1999 and changing organizational initiatives.

In 2000, NETL management established a set of environmental performance measures for the NETL sites. These performance measures included:

C Goal: $\quad$ ES\&H corrective actions are managed appropriately.

Target: $\quad$ All urgent ES\&H corrective actions completed within 7 days of posting; 75 percent of all other ES\&H corrective actions completed according to (severity) schedule.

C Goal: $\quad$ Mandatory ES\&H training is completed according to schedule.

Target: $\quad 95$ percent of required, scheduled training completed within 2 weeks of due date.

C Goal: $\quad$ Merge and issue ES\&H orders, plans, and procedures.

Target: $\quad 80$ percent of merged, streamlined, ISM-based ES\&H directives are issued.

C Track: $\quad$ Regulated Pollutant Effluents -- Total pounds of permitted, regulated pollutants in air and water releases.

Target: $\quad$ Decreasing trend.

C Track: Hazardous Waste Generated -- Total cubic feet of hazardous waste shipped.

Target: Decreasing trend.

C Track: Reportable Occurrences of Releases to the Environment -- Releases of radionuclides, hazardous substances, or regulated pollutants that are reportable to federal, state, or local agencies.

Target: $\quad$ Decreasing trend.

Based on the analysis of NETL environmental performance for CY2000, all of the above goals were classified as being "on target."

\subsubsection{Environmental Training Programs}

NETL provided several ongoing environmental training opportunities during the year. These included the Hazardous Waste Operations and Emergency Response Standard (HAZWOPER), Hazardous Waste Handlers, and Hazardous Waste RCRA for new lab and project personnel. Several new courses were provided and completed using the NETL Computer Based Training (CBT) System. To support the implementation of Integrated Safety Management (ISM), two CBT courses were developed for all NETL employees on ISM and a specialty course presented for Contracting Officers Representatives (CORs). These ISM courses provided knowledge of how environmental programs were integrated under the umbrella of ISM, and of how ISM was being implemented at NETL. The specialty course was to help CORs understand and raise awareness of the environmental requirements for application to management of contracts and financial assistance agreements. This included an overview of the major 
environmental requirements including Waste Management, Air Quality, and Water Quality. Individual training opportunities for professional development were provided to environmental personnel. 


\subsubsection{Pollution Prevention and Waste Minimization Program}

Recycling of wastes (or prevention of generation) is an integral part of the NETL pollution prevention/waste minimization program.

NETL-Pittsburgh is mandated to recycle by the State of Pennsylvania under Pennsylvania Act 101Municipal Waste Planning, Recycling, and Waste Reduction Act. The Morgantown site is not required to recycle by West Virginia State regulations.

Both sites maintained recycling programs, and the following inherently non-hazardous items were recycled whenever possible: office wastes (mixed paper, newspapers, magazines, and toner cartridges), scrap metal, aluminum beverage containers, corrugated cardboard, and telephone books. In addition, used motor oil was recycled offsite for re-refining and subsequent re-use. Some process solvents were placed into fuels blending programs for beneficial re-use as fuels.

Batteries (lead-acid, dry-type, other) were broken down into re-useable components, whenever possible, rather than placed into landfills. Vehicle tires were sent offsite for use as fuel or for use in a shredded rubber re-use process. Wooden pallets were placed into the recycle stream for re-use as pallets or landscape mulch.

In addition, process-related or -derived materials (both raw materials and non-hazardous waste products) such as unused waste coal or process-generated fly ash were, whenever possible, reclaimed for beneficial use as raw materials useable in an offsite process (e.g., boiler fuel or cement, respectively).

\subsubsection{Clean Water Action Plan}

NETL has many environmental programs for protecting public drinking water supplies. This includes both surface water and well water supplies. Some programs specifically target water protection, while others protect water indirectly.

The discharge of stormwater is regulated by a National Pollution Discharge Elimination System (NPDES) permit. Stormwater samples are collected quarterly during the year and reported to State regulatory authority. There were no stormwater discharge violations in 2000 from either NETL site. Please see section 2.4 "Clean Water Act (CWA) and the NPDES" of this report for a complete discussion on the NETL stormwater protection program.

All domestic sewage and industrial wastewater were delivered to a treatment authority. NETL did not treat any sewer waste, but did operate an industrial wastewater pretreatment facility at the Pittsburgh site. The industrial wastewater pretreatment facility was issued one Notice of Enforcement Action -Letter of Violation citing five violations of the NETL Industrial Sewer Use Permit discharge limits in 2000. The sanitary sewer subinterceptor location was also issued one Notice of Enforcement Action -Letter of Violation citing four violations of the NETL Industrial Sewer Use Permit discharge limits in 2000. Please see section 3.7.2 "Environmental Occurrences" of this report for a complete discussion of the Letters of Violation. 
NETL operated a groundwater protection program in conformance with State requirements. No contamination to the groundwater was detected at any of the groundwater sampling locations in 2000. Please see section 7.2 "Groundwater Monitoring" of this report for additional information on the NETL groundwater protection program.

NETL maintained a waste minimization/pollution prevention program which helped preserve clean water. Employees were required to purchase chemicals in the smallest quantity necessary. All site floor drains were sealed to prevent the accidental discharge of chemicals into the wastewater system. Please see section 3.7.5 "Pollution Prevention and Waste Minimization Program" of this report for additional information on the NETL waste minimization/pollution prevention program.

NETL maintained a comprehensive PCB, asbestos, and lead program which protected the water. Please see section 2.7 "Toxic Substances Control Act (TSCA)" for additional information on the NETL TSCA program.

NETL returned all radioactive materials, such as smoke detectors, spectroscopes and liquid scintillation counters to the manufacturer for recycling.

NETL maintained an Integrated Pest Management Program which protected water from contamination of pesticides and herbicides. Please see section 2.8 Federal Insecticide, Fungicide, and Rodenticide Act for more information on the NETL Pest Management Program.

NETL maintained a backflow prevention program aimed at preventing entry of contaminants into the public drinking water system. NETL has installed a backflow preventor at the main valve to the facilities, as well as on every floor of every building. These backflow preventors were inspected tested biannually. There has never been an incident involving contamination of the public drinking water by an NETL controlled operation.

Finally, NETL has eliminated all underground storage tanks, as they were perceived to be a potential threat to the community groundwater. 


\section{Environmental Management Information}

The NETL sites are staffed by ES\&H professionals who reviewed activities to assure that the sites complied with environmental laws and regulations. All onsite research projects and support activities were reviewed by ES\&H staff, in conjunction with the safety analysis and review system (SARS) processes, for possible impacts on air, surface water, groundwater, and soil. Applicable federal, state, and local regulations potentially affecting these activities are reviewed and compliance assured before approval by the ES\&H staffs.

\section{Integrated Management Activities \\ On October 15, 1996, the Secretary of Energy implemented the Safety Management System Policy at all U.S. Department of Energy sites and facilities. This policy established a formal process to plan, perform, assess and improve the safe and responsible environmental conduct of work. The primary DOE Safety Management System is called the Integrated Safety Management System (ISMS). The ISMS objective is to assure that DOE and its contractors systematically integrate ES\&H requirements and work practices into all planning and execution.}

On April 27, 1998, the NETL Director, Rita A. Bajura, issued a memorandum implementing the policy by developing a site-wide ISM Plan. All employees were expected to know the ISM principles, understand their roles and responsibilities, and be accountable for carrying out their ISM responsibilities.

To ensure that NETL had implemented ISM, a Combined Phase I and II Verification Review was performed June 5-9, 2000. Document reviews and interviews of NETL and site support contractor managers and workers at NETL's two sites (Morgantown, WV, and Pittsburgh, PA) were conducted. The verification team used these data and information to evaluate the adequacy of the processes defined in the NETL ISMS program description and implementing procedures. The degree to which these processes were implemented was observed and evaluated at the institutional/senior management, project/supervisor/facility, and worker/activity levels at both sites. Finally, the NETL interface with both onsite and offsite support contractors was assessed.

NETL has undergone substantial changes in its organization, including a new designation as a National Laboratory. The ISM review incorporated this into the evaluation and assessed the implementation of the key site-level ISMS documents and work processes.

The review verified that NETL has systematically integrated ISMS into work practices at all levels. The verification team concluded that

- $\quad$ NETL ISM system description embodied the seven guiding principles and addressed the five core functions of Integrated Safety Management.

- $\quad$ The observed and evaluated ISMS elements incorporated active, adequate, and in some cases, excellent mechanisms to define and realized DOE expectations. 
C At both sites, the observed and evaluated ISMS elements also exhibited defined areas that can be improved, which would further enhance ES\&H protection.

C Responsibilities within NETL have been clearly identified, and management personnel understood and accepted their responsibilities.

C NETL has appropriate mechanisms in place to define and carry out DOE ES\&H expectations. NETL recognized that implementing and improving ISMS is a continuous process.

The verification team observed no deficiencies, identified several areas for improvement, and concluded the NETL has effectively carried out ISM. On June 21, 2000, the NETL Director declared ISM implemented at NETL.

In implementing the NETL ISM core function for continuous improvement, NETL began reviewing the requirements for ISO 14001 certification. An ISO 14001 gap analysis will be performed in early 2001, and corrective actions and recommended improvements to the NETL ISM program will be implemented during the later part of 2001 and into 2002. It is projected that NETL will pursue ISO 14001 certification during mid-year 2002. ISO 14001 certification will be included in the overall ISMS as an example of our commitment to continuous improvement. 


\section{Environmental Radiological Program Information}

The Atomic Energy Act (AEA) of 1954, and its amendments, are the Federal laws that mandate DOE control radioactive materials in order to protect public safety and health. DOE orders and Nuclear Regulatory Commission (NRC) and EPA regulations are based on the AEA. Although DOE facilities are generally exempt from NRC regulations, the facilities are to meet the intent of these regulations.

NETL does not generate, transport, process, treat, or have onsite permanent disposal of any radioactive waste. However, NETL used, in the conduct of research, instrumentation that contained radioactive sources. Also, four phosphorescent exit signs were used in the Morgantown site's hazardous waste facility. An inventory of radiation sources was maintained by the radiation safety officer, indicating the item, isotope, quantity, custodian, location, status, and activity. Table 6 lists the 2000 source inventory. NETL did not release any radionuclides into the environment, as all of its sources are sealed and are used in instrumentation.

The radiation monitoring performed at NETL consisted of a limited number (less than 20) of personal dosimeter badges and rings supplied under a contract with Siemens Gammasonics, Inc. In addition, leak testing was conducted on all applicable sealed sources with analysis also performed by Siemens Gammasonics, Inc. for NETL-Morgantown. Leak testing is conducted on all applicable sealed sources at Pittsburgh by Applied Health Physics. 
Table 6. NETL Radioactive Materials Inventory for 2000

\begin{tabular}{|c|c|c|c|c|}
\hline Isotope & Quantity & Activity & Supplier/Source & Location \\
\hline $\mathrm{Kr}-85$ & 1 & $2 \mathrm{mCi}$ & $\begin{array}{l}\text { Model No. } 3077 \\
\text { Serial No. } 700 T \\
\text { Thermo-Systems, Inc. }\end{array}$ & MGN \\
\hline $\mathrm{Kr}-85$ & 1 & $2 \mathrm{mCi}$ & $\begin{array}{l}\text { Model No. } 3012 \\
\text { Serial No. } 467 T \\
\text { Thermo-Systems, Inc. }\end{array}$ & MGN \\
\hline $\mathrm{Kr}-85$ & 1 & $2 \mathrm{mCi}$ & $\begin{array}{l}\text { Model No. } 3012 \\
\text { Serial No. 626T } \\
\text { Thermo-Systems, Inc. }\end{array}$ & MGN \\
\hline $\mathrm{Kr}-85$ & 1 & $2 \mathrm{mCi}$ & $\begin{array}{l}\text { Model No. } 3077 \\
\text { Serial No. 373T } \\
\text { Thermo-Systems, Inc. }\end{array}$ & MGN \\
\hline $\mathrm{Kr}-85$ & 1 & $2 \mathrm{mCi}$ & $\begin{array}{l}\text { Model No. } 3077 \\
\text { Serial No. } 697 \mathrm{~T} \\
\text { Thermo-Systems, Inc. }\end{array}$ & MGN \\
\hline $\mathrm{Ni}-63$ & 1 & $15 \mathrm{mCi}$ & $\begin{array}{l}\text { Model No. } 6000204 \\
\text { Serial No. } 533 \\
\text { Perkin-Elmer Corporation }\end{array}$ & MGN \\
\hline Sc-46 & 1 & $0.065 \mathrm{mCi}$ & $\begin{array}{l}\text { University of Missouri } \\
\text { *Source encapsulated by a } \\
\text { nylon bead. }\end{array}$ & MGN \\
\hline Sc-46 & 1 & $0.046 \mathrm{mCi}$ & $\begin{array}{l}\text { University of Missouri } \\
\text { *Source encapsulated by a } \\
\text { nylon bead. }\end{array}$ & MGN \\
\hline Ra-226 & 1 & $9 \mathrm{FCi}$ & $\begin{array}{l}\text { Model No. B-5 } \\
\text { Serial No. } 11205 \\
\text { Mettler Corporation }\end{array}$ & MGN \\
\hline Ra-226 & 1 & $21 \mathrm{FCi}$ & $\begin{array}{l}\text { Model No. M-5 } \\
\text { Serial No. } 17032 \\
\text { Mettler Corporation }\end{array}$ & MGN \\
\hline Phosphate Rock & 1 & $\begin{array}{l}\text { Consumer } \\
\text { Product }\end{array}$ & $\begin{array}{l}\text { Model No. } 1080 \\
\text { Sun Nuclear Corporation }\end{array}$ & MGN \\
\hline Ra-226 & 1 & $9 \mathrm{FCi}$ & $\begin{array}{l}\text { Model No. B-5 } \\
\text { Serial No. } 13805 \\
\text { Mettler Corporation }\end{array}$ & MGN \\
\hline $\mathrm{H}-3$ & 1 & $20 \mathrm{Ci}$ & $\begin{array}{l}\text { Model No. B100/U10 } \\
\text { Serial No. } 575263 \\
\text { SRB Technologies }\end{array}$ & MGN \\
\hline $\mathrm{H}-3$ & 1 & $20 \mathrm{Ci}$ & $\begin{array}{l}\text { Model No. B100/U10 } \\
\text { Serial No. } 574434 \\
\text { SRB Technologies }\end{array}$ & MGN \\
\hline
\end{tabular}


Table 6. NETL Radioactive Materials Inventory for $\mathbf{2 0 0 0}$ (continued)

\begin{tabular}{|c|c|c|c|c|}
\hline Isotope & Quantity & Activity & Supplier/Source & Location \\
\hline H-3 & 1 & $20 \mathrm{Ci}$ & $\begin{array}{l}\text { Model No. B100/U10 } \\
\text { Serial No. } 574435 \\
\text { SRB Technologies }\end{array}$ & MGN \\
\hline H-3 & 1 & $20 \mathrm{Ci}$ & $\begin{array}{l}\text { Model No. B100/U10 } \\
\text { Serial No. } 574436 \\
\text { SRB Technologies }\end{array}$ & MGN \\
\hline Co-57 & 1 & $12 \mathrm{mCi}$ & $\begin{array}{l}\text { Model No. IPL CUS } \\
\text { Serial No. EE661 } \\
\text { Isotope Products Lab }\end{array}$ & MGN \\
\hline Cs-137 & 1 & $1 \mathrm{FCi}$ & Tele-Atomic, Inc. & MGN \\
\hline Cs-137 & 1 & $10 \mathrm{FCi}$ & Tele-Atomic, Inc. & MGN \\
\hline Ba-133 & 1 & $1 \mathrm{FCi}$ & Tele-Atomic, Inc. & MGN \\
\hline Ba-133 & 1 & $10 \mathrm{FCi}$ & Tele-Atomic, Inc. & MGN \\
\hline TI-204 & 1 & $1 \mathrm{FCi}$ & Tele-Atomic, Inc. & MGN \\
\hline TI-204 & 1 & $10 \mathrm{FCi}$ & Tele-Atomic, Inc. & MGN \\
\hline Po-210 & 4 & $\begin{array}{l}\text { Consumer } \\
\text { Product }\end{array}$ & Anti-Static Brushes & PGH \\
\hline Cs-137 & 3 & $\begin{array}{l}40 \mathrm{mCi}(2) \\
20 \mathrm{mCi}(1)\end{array}$ & $\begin{array}{l}\text { Ronan Engineering Company, } \\
\text { Model } 137 \\
\text { Level Density Gauge }\end{array}$ & PGH \\
\hline Cs-137 & 4 & $\begin{array}{l}30 \mathrm{mCi}(3) \\
6 \mathrm{mCi}(1)\end{array}$ & $\begin{array}{l}\text { Berthold Systems, Inc. Model } \\
\text { LB-7400D } \\
\text { Level Density Gauges }\end{array}$ & PGH \\
\hline Assorted & 80 & $\begin{array}{l}\text { Consumer } \\
\text { Product }\end{array}$ & Smoke Detectors & PGH \\
\hline Ni-63 & 1 & $15 \mathrm{mCi}$ & $\begin{array}{l}\text { Gas Chromatograph Electron } \\
\text { Capture Device }\end{array}$ & PGH \\
\hline
\end{tabular}




\section{Environmental Non-Radiological Program Information}

The nonradiological monitoring program at NETL was designed to meet permit requirements and to assess the effectiveness of ongoing waste minimization and pollution prevention programs. The 2000 monitoring program focused on industrial wastewater, stormwater, groundwater, hazardous waste, and soil. The NETL sites are not required and did not perform air emissions monitoring for most of its individual air emission sources. Specific monitoring and permit information is in Section 2.4 of this report.

\subsection{Stormwater Monitoring}

The primary objectives of the stormwater discharge monitoring program are to comply with a multiple federal party National Pollutant Discharge Elimination System (NPDES) permit at the Pittsburgh site, and a general storm water discharge permit at the Morgantown site. Quarterly (outfalls 001 and 002) and weekly samples (outfall 101) were taken at the Pittsburgh site, and semiannual samples were taken at the Morgantown site. Pittsburgh storm water flows to Lick Run and ultimately to the Monongahela River. Morgantown storm water flows to Burroughs Run and West Run, and ultimately to the Monongahela River. Table 7 in the appendix contains monitoring data related to stormwater discharges for NETL's sites.

\subsection{Clarifier Effluent Monitoring}

The Morgantown site was permitted by MUB to connect to the city's POTW and was required by that permit to conduct monthly monitoring of the clarifier effluent. The wastewater was treated to adjust the $\mathrm{pH}$, if necessary to meet the permit limitation. Clarifier effluent monitoring parameters and the sampling results are presented in the appendix.

The Pittsburgh site's effluent water consisted of a pre-treated industrial wastewater component combined with the sanitary wastewater stream. The primary objective of the industrial wastewater monitoring program was to comply with the Pleasant Hills, Pennsylvania, POTW pretreatment requirements. Table 8 in the appendix contains industrial wastewater effluent data for the NETL sites.

\subsection{Waste Minimization}

Quarterly hazardous waste generation rates for the past 7.5 years have been, for the most part, significantly lower than the rates of prior years. The decrease is partially reflective of several waste minimization efforts and initiatives instituted over that time period. However, quarterly hazardous waste generation rates at NETL have historically exhibited wide variations since they are dependent upon many complex factors. These factors include, but are not limited to, project schedules and operational 
activities, facility management and maintenance activities, responses to various audits or assessments (e.g., corrective action plan response to the tiger team assessment), the R\&D nature of the facility, and significant management initiatives.

Monitoring the generation of hazardous and non-hazardous waste allowed NETL to assess the effectiveness of its waste minimization program. Reducing or minimizing the waste generated decreased waste management needs (e.g., storage, transportation, and disposal needs), thereby reducing the cost, environmental impact, and liability of such operations. 


\section{$7 \quad$ Site Hydrology, Groundwater Monitoring and Public Drinking Water Protection}

In September 1985, the Secretary of Energy announced a series of initiatives designed to strengthen the ES\&H programs and activities within the U.S. Department of Energy. As required by Chapter III of DOE Order 5400.1, General Environmental Protection Program, NETL developed groundwater protection management programs at the two sites. The purpose of the order was to establish environmental protection requirements, authorities, and responsibilities for DOE operations and to ensure compliance with applicable federal, state, and local environmental laws; executive orders; and DOE policies. The intent of DOE 5400.1 and the groundwater protection management program was to ensure that facility RCRA and CERCLA actions were addressed. Based on activities conducted at the sites, NETL was not subject to groundwater monitoring requirements as set forth under RCRA and CERCLA.

\subsection{Site Hydrology}

\section{Morgantown Site}

Most of Monongalia County is underlain by rocks of low permeability, which consequently yield water at low rates. Wells nearest the Morgantown site typically had yields of $0.1 \mathrm{~L} / \mathrm{s}$ (1.6 gallons per minute, gpm) or less. The principle aquifers were found in the Pennsylvanian-aged Conemaugh Group and the Pottsville Group. Aquifers of the Conemaugh Group outcrop at the Morgantown site were the source of most of the domestic water supplies near the area under water table (unconfined) conditions. Aquifers of the Pottsville Group, which are quite deep but are regarded as the most important aquifers in the county, yielded up to 250 gallons per minute (gpm) under artesian pressure, but averaged about 45 gpm. The Pottsville Group aquifers are separated from the Conemaugh Group aquifers by several hundred feet of bedrock. There is no apparent communication between these aquifers. One of the aquifers of the Conemaugh Group was sampled for possible contamination by monitoring wells at NETL, the Morgantown sandstones. The recharge area for this aquifer is east of Morgantown in the area of Chestnut Ridge, and discharges regionally into the Monongahela River west of the site. The Morgantown sandstone outcrops around the perimeter of the NETL property along Burroughs Run, West Run, and the Monongahela River. There are small springs in a number of places along these creeks and the Monongahela River where water flows from fractures in the Morgantown sandstone.

Unconformably overlying the Pennsylvanian rocks at the site is up to 70 feet of Pleistocene-aged unconsolidated Lake Monongahela sediments. These consist of a basal clayey sand that ranges from 10 to 20 feet in thickness, informally named the "A" aquifer, overlying interbedded clays and clayey sands, informally named the "B-C" aquifer, and a predominately sand unit, the " $\mathrm{D}$ " aquifer, which occurs at the surface on the southwest corner of the site. These sediments were deposited in stream and lacustrine environments from the glacial Lake Monongahela. The "A" and "B-C" units are water bearing under the developed part of the site and both are monitored for possible groundwater contamination at NETL. Both units extend off the site, and recharge is probably mostly from offsite, as the near-surface 
sediments are dominated by very low permeability clays in the developed area of the site. Both aquifers outcrop north of the developed area on the property, forming springs and small creeks which drain into West Run. There are probably springs and seeps along the Monongahela River from this unit as well.

The groundwater monitoring program provides the following information:

C Baseline conditions of groundwater quality and quantity related to the site.

C Details of the groundwater/surface water relationship.

C Identification of potential sources of groundwater contamination.

C Data useful in the development and implementation of remedial measures for any NETL facilities/sites that could pose a concern to the environment.

C Measurement of petroleum hydrocarbons (diesel range organics) in groundwater at selected wells surrounding abandoned (or previously removed) storage tanks and oil spill areas, per state request.

\section{Pittsburgh Site}

Currently, 23 groundwater monitoring wells are at various locations throughout the Pittsburgh site. The groundwater management plan implementation included groundwater monitoring well installation, well development, and sampling and analysis to be completed in two phases. Phase I activities occurred from November 16, 1992, through February 12, 1993, and consisted of the installation of 16 bedrock wells, two piezometer clusters, and two stream gauging weirs. Phase II occurred from November 17 , 1993, through February 17, 1994 and consisted of 12 additional bedrock wells. A concrete stream gauging station was also constructed during Phase I. Finally, a supplemental well was installed in June 1995. Due to low water production, 6 wells were abandoned in October 1998 in accordance with PA Act 610, Water Well Driller License Act.

The Pittsburgh site has two groundwater flow patterns. Groundwater flowing in the shallow, weathered bedrock aquifer may percolate along the soil/bedrock interface and along near-vertical stress relief fractures, and follows the general site topography, flowing from the tops of hills on the site, generally perpendicular to ground surface elevation contours. This flow is directed by the intervening valleys toward Lick Run Valley, where it joins the water-bearing unit in the valley and adds to the baseflow of Lick Run itself. Some of this flow also discharges as springs on the hillsides or in the valleys.

The second flow pattern is associated with the deep aquifer. Groundwater in this zone generally flows east toward Lick Run Valley, where it is joined by the water of the shallow zone as it flows off the hillsides.

For purposes of groundwater monitoring, the Pittsburgh site was divided into three separate areas generally referred to as the main plateau area, the valley fill area (which includes the 900 area, building 141, and the 920 area, 2.1 acre, 2.2 acre, and 4.0 acre properties), and the building 167/triangle parking lot area. These areas were selected based on current operations and 
historical areas of contamination. During 2000, a semiannual groundwater sampling and analysis program involving two contamination detection programs was completed.

Tables 10-24 in the appendix present the results of groundwater data collected. This analysis consisted of the following:

(1) Investigation for immiscible (light or dense) organic phases, continued measurement for specific constituents identified during the initial monitoring phase, RCRA (background year) sampling/analyses, and subsequent RCRA sampling/analyses with statistical comparisons of contamination indicator parameter data.

(2) Measurement of petroleum hydrocarbons (diesel range organics) in groundwater at selected wells surrounding inactive underground storage tanks and oil spill areas, per PaDEP request.

Results of laboratory analyses produced a variety of groundwater chemical constituent data that must be evaluated to determine whether the facility is contaminating the groundwater.

Downgradient contamination is indicated by one, or a combination of, the following conditions:

C Immiscible organic phases are detected downgradient, and contaminant concentrations are substantively elevated compared to upgradient/background (or none detected upgradient), and substantively exceed drinking water standard maximum contaminant levels (MCLs).

C As defined by Appendix IX to 40 CFR Part 264, dissolved hazardous waste constituents are detected downgradient, and concentrations are substantively elevated compared to upgradient/background (or none detected upgradient) and substantively exceed MCLs (or human health evaluations identify a risk).

Statistical comparisons of semiannual contamination indicator data (upgradient and downgradient wells) were made against appropriate upgradient/background well data. If statistically significant downgradient differences exist (and are subsequently confirmed by immediate resampling and repeating of statistical analyses), then contamination will be indicated and a human health and ecological risk assessment and/or groundwater quality assessment program will be warranted. If no downgradient statistically significant differences are calculated, routine monitoring will continue.

\subsection{Groundwater Monitoring}

\section{Morgantown Site}

The objectives of groundwater monitoring were to provide environmental surveillance of the two shallow aquifers, the first regional aquifer, and a closed and abandoned wastewater pond. A total of 22 groundwater wells were monitored semiannually: four wells (three down gradient and one up gradient) in the Morgantown aquifer, thirteen wells (ten down gradient and three up gradient) in the " $\mathrm{A}$ " aquifer, and 
five wells in the "B-C" aquifer. The wells that monitor the abandoned wastewater pond are in the "A" aquifer. 
The groundwater monitoring results for the Morgantown site are presented in Tables 19-24. None of the results exceeded West Virginia groundwater standards. Most parameters were monitored in detection mode, that is, results were typically non-detectable. For the parameters that were detected, a statistical analysis was conducted to compare up gradient and down gradient values. The following is a summary of the results:

- Nitrate, as nitrogen, was consistently higher than background levels in one well in the shallowest "B-C" aquifer and in many wells in the deeper unconsolidated "A" aquifer, but not higher in the regional Morgantown aquifer. No wells exceeded the West Virginia groundwater limit.

- Sodium and chloride were higher than background wells in the vicinity of roadways and walkways where salt is applied for de-icing purposes. West Virginia has not set a standard for sodium or chloride.

- Sulfate was consistently higher than background in detection wells in two wells in the " $\mathrm{A}$ " aquifer. West Virginia has not set a standard for sulfate.

- Fluoride was higher than background in three wells in the " $\mathrm{A}$ " aquifer and one well in the "BC" aquifer. No wells exceeded the West Virginia groundwater limit.

No other parameters were statistically significantly higher in down gradient wells than up gradient levels.

\section{Pittsburgh Site}

The results of the NETL-Pittsburgh Groundwater Detection Monitoring Program are presented in Tables 10 - 18. The results were compared against Federal and State standards for groundwater. The following is a summary of the results:

C Well VFW-3 exceeded standards for tetrachloroethene. This well has previously exceeded tetrachloroethene standards. It was located adjacent to a laboratory wastewater holding tank, which was connected to a french drain. The overflow was connected to the sanitary sewer more than twelve years ago.

C Sodium and chloride exceeded standards for 23 and 18 wells, respectively. The levels have been attributed to the past applications of salt for de-icing purposes.

C Manganese, sulfate, and iron exceeded standards for sixteen, seven, and eight wells, respectively. This was attributed to past mining activities.

C Wells MPW-1, MPW-8 and VFW-11 exceeded standards for nickel. In the past, the level was attributed to the interaction of the sodium and chloride with the stainless steel well casing.

C Total dissolved solids exceeded standards for twenty-three wells.

Statistical analysis was conducted on the indicators of groundwater contamination $(\mathrm{pH}$, conductivity, TOX, and TOC). The analysis compared the up gradient wells to the down gradient wells. The following are the results of the statistical analysis:

C The $\mathrm{pH}$ values were outside the background tolerance levels in Wells MPW-4D and MPW10. 
C The conductivity values for the Main Plateau Wells had no significant change, while Wells VFW-6 and VFW-7 were outside the background tolerance levels.

C No TOC values were outside the background tolerance levels.

C The TOX values had no significant change.

An element of the Groundwater Detection Program is the surface water-groundwater interaction. A piezometer was monitored monthly along Lick Run upstream of the site and a piezometer was monitored weekly along Lick Run adjunct to the site to determine if Lick Run is a "gaining" or "losing" stream. A "gaining" stream has groundwater flowing to the stream, while a "losing" stream has surface water flowing to the groundwater. The data collected indicates that Lick Run upstream of the site is a "gaining" stream, seven of the twelve months, while Lick Run adjunct to the site is always a "gaining" stream.

To date, no significant contamination has been detected in samples collected from any of the groundwater monitoring wells. Results of groundwater monitoring are given in Tables $10-24$ of the appendix. 


\section{Quality Assurance}

\section{Environmental Sampling and Analysis}

All environmental analyses at NETL were performed by an off-site subcontractor in accordance with

NETL specifications. The subcontractor was tasked with the fundamental responsibility of establishing and maintaining programs that ensure the reliability and validity of all analytical laboratory and field data. NETL's Quality Assurance (QA) Program demands continuing evidence of the subcontractor's commitment to fulfilling these obligations. The subcontractor's QA Program was implemented throughout the analytical process from preparation for sampling through data management and reporting to ensure reliable and valid analytical data.

Environmental samples at NETL were usually collected by off-site subcontractor personnel. These subcontractors were well versed in U.S. EPA sampling protocol. Because of the nature of the sampling event, stormwater sampling was performed by the on-site contractor using EPA protocol. The following types of samples were collected at NETL:

Groundwater Monitoring Wells - Groundwater samples were collected following Standard Operating Procedure (SOP) for groundwater monitoring well sampling.

Water/Wastewater/Other Discharges - Grab samples were collected following the same basic principles outlined in the SOP for groundwater monitoring well sampling.

Composite samples were taken using either flow or time weighted automatic samplers.

Sediments, Solids, Drums, Hazardous Wastes - Representative samples were taken by subcontractor personnel following correct sampling protocols. Adherence to appropriate SOP's (e.g., sample containers, preservation) was maintained.

\section{Standard Operating Procedures}

NETL required the subcontractor to have Standard Operating Procedures (SOPs) in place for all analytical, technical and administrative procedures.

\section{Training}

The subcontractors ensured that their personnel were trained both technically and with respect to the requirements of their Corporate Quality Assurance Manual, including the implementation of the quality assurance procedures.

\section{Testing}

Sampling and analytical services have been provided to NETL by the subcontractor for over fifteen years. All testing was performed using approved EPA procedures (recent edition of SW-846) and met the requirements of any federal/state permits issued to NETL. Samples included

- water or wastewater samples 
- $\quad$ solid waste samples

- hazardous waste samples

- soil samples

- $\quad$ stream sediment samples

- R\&D project samples

- process samples.

Sample sources included:

- industrial wastewater discharge to the local POTW

- various sewer system discharges and manholes (i.e. stormwater, sanitary wastewater, process water, and industrial/contaminated wastewater)

- groundwater monitoring wells

- potable water system

- streams and rivers

- various pits and sumps

- R\&D projects

- $\quad$ spill and/or leaks

- $\quad$ soils

- $\quad$ solid and/or hazardous waste streams.

The testing process followed well documented laboratory quality control (QC) protocol. These procedures defined the requirements for the generation of QC data, subsequent evaluation of the data, and the reporting procedures and statistical data manipulation procedures used to provide feedback about the performance of an analytical system.

Where method guidelines were not available, the acceptance criteria used was EPA's contract lab procedure (CLP). If CLP guidelines were not available, internal acceptance criteria were used. It was the responsibility of each analytical staff member to perform all necessary quality control procedures and measurements, and to complete all appropriate documentation. Many of these requirements were specified in the methodologies used and were addressed in specific method SOPs.

There were, however, several quality control policies that were generally applicable to the majority of analytical procedures:

- Prior to the analysis of any sample, the analytical system must have met the required calibration criteria.

- Prior to any sample analysis, an instrument blank must have been performed to demonstrate that the analytical system is void of contamination.

- One method blank must have been analyzed for every prep or analytical batch.

- One laboratory control sample must have been analyzed for every prep or analytical batch.

- One matrix spike or matrix spike duplicate must have been performed for every prep batch. 
Batching was the way in which groups of samples were assigned to specific QC measurements. As a general rule, each prep batch had no more than 20 field samples of the same matrix, a method blank, a laboratory control sample, and a matrix spike/matrix spike duplicate. The contents and duration of an analytical batch were clarified in the method SOPs.

\section{Quality Control Data}

Outlined below are the various quality control measurements utilized by the analytical staff to assess data quality:

Duplicate Analysis: Two independent measurements for a particular analyte were acquired from the same analytical system on the same sample. This quality control measurement provided information concerning analytical precision.

Matrix Spike Analysis: A known concentration of the target analyte was added to the sample matrix. This spike analysis provided information concerning the analytical accuracy and matrix effect the sample may have on the recovery of the target analyte.

Matrix Spike/Matrix Spike Duplicate Analysis: This analysis was a matrix spike analysis performed in duplicate. This procedure provided information concerning both the precision and accuracy of the analytical system.

Surrogate Spike Analysis: A specific compound at a known concentration was added to the sample matrix. Because the surrogate compound was generally similar to the target compounds, its recovery should indicate some correlation to target compound recovery.

Laboratory Control Sample: This analysis was an independent source standard of known concentration. This type of analysis was necessary for verifying good laboratory practice.

\section{Control Charts}

A control chart is a means of looking at trends in the data. By having available a current control chart, the analyst can make determination of the current $\mathrm{QC}$ data to help judge the status of the analysis. The type of control chart used was the Shewhart Control Chart in the form of $\mathrm{x}, \mathrm{s}$ (X-bar, sigma).

The chart allowed the analyst to determine which data points (representing QC measurement events) were part of an out-of-control population and therefore indicative of possible problems in the analytical system. This procedure allowed the analyst to empirically differentiate between normal variation inherent in any measurement process and that variation attributable to a process moving away from the normal.

The chart was particularly useful for uncovering "trending." Trending is the characteristic of data in a given population to cluster on one side of the mean or show greater separation from the mean when the population is changing. Such behavior indicates to the analyst that measurement conditions may also be changing and investigation of the system may be warranted. 


\section{Reporting}

All associated QC data was reported for each sample being analyzed. This was reported using the SOPs for Data Package Preparation.

\section{Waste Disposal}

Upon completion of all required analyses, all remaining samples, sample material, and contaminated sample containers were managed and/or disposed of in accordance with all applicable laws and regulations (RCRA regulations). The final disposition of these items was approved by NETL and was fully documented in quarterly Sample Disposition Reports.

All hazardous waste generated at NETL was disposed of in accordance with applicable Federal Regulations (EPA). Waste was placed in specified containers, labeled, and shipped to a contracted waste disposal firm.

The QA procedure for hazardous waste manifesting involved between two and four separate reviews, depending upon the complexity and quantity of the shipment. The Uniform Hazardous Waste Manifest was created by the licensed hazardous waste hauler one to two days prior to the shipping date. This provided an opportunity for the site support contractor hazardous waste technicians, project engineer, and DOE personnel to review and correct or adjust the Manifest to ensure that it complies with DOT and RCRA regulations. Changes were made to the manifest if needed and then it was signed by the DOE Hazardous Waste Program Manager. All personnel involved in hazardous waste disposal were trained annually with to ensure familiarity with all applicable RCRA and DOT regulations.

During the shipping activities NETL QA personnel were present to ensure:

1. Hazardous waste manifest were prepared properly.

2. The licensed transporter complied with all applicable DOT placarding requirements.

3. Hazardous waste did not exceed the permissible 90-day retention period.

4. The transport vehicle was properly identified (EPA ID Number, State Transporter Number).

5. The transporter driver had the proper DOT licensing.

6. Spill kits were available to the transport driver during transit.

7. The total number of loaded items conformed to the value listed on the Manifest.

8. Hazardous waste containers had the proper EPA labeling waste identification on the labels.

Any deficiencies were immediately corrected prior to the transport of the hazardous waste to the off-site TSD facility. There were no deficiencies in transported waste.

\section{Laboratory Certifications}

The subcontractor laboratory held the following certifications:

- State of Colorado Department of Health for Drinking Water Analysis

- State of Delaware Department of Health for Drinking Water Analysis

- State of Kentucky Department of Health for Drinking Water analysis 
- State of Virginia Department of Health for Drinking Water Analysis

- State of Maryland Department of Health for Drinking Water Analysis

- State of Massachusetts Department of Health for Drinking Water Analysis

- State of Minnesota Department of Health for Drinking Water Analysis

- State of Michigan Department of Health for Drinking Water Analysis

- State of New Jersey Department of Health for Drinking Water Analysis

- State of Tennessee for Underground Storage Tank Program

- U.S. Department of Agriculture (USDA-APHIS) for the importation of foreign soil

- U.S. Drug Enforcement Agency for handling of controlled substances

- West Virginia Department of Health for Drinking Water Analysis

- West Virginia Division of Environmental Protection for NPDES Laboratory Certification Program

- West Virginia Board of Pharmacy for handling of controlled substance.

\section{Laboratory Proficiency Programs}

The subcontractor laboratory actively and regularly participated in various external performance evaluation programs, internally administered blind performance evaluations, and an internal corporate round robin program.

\section{Performance Evaluation Samples (PES)}

These samples were defined as third-party prepared check samples, whose values were known only to the third party prior to completion of the analyses. The subcontractor was made aware that the samples were PES but did not have access to the true value information until after the results were submitted. In all cases, these were analyzed by many laboratories and the results were reported so as to reference them to overall laboratory performance ("round robin" analysis). The PES, therefore, gave an independent measure of laboratory performance.

\section{Internal Blind Performance Evaluation Samples (IBPES)}

These samples, frequently referred to as "blinds," were check samples that were purchased or prepared by the QA/QC office and submitted to the laboratory as a regular sample. The lab staff had no knowledge that the sample was a check sample and it was processed in the normal fashion. While the PES gave a good assessment of optimum performance, the IBPES assessed usual performance. The QA/QC office was required to pass at least one IBPES through each analytical group (measuring as many parameters as possible) at a minimum of twice annually. Frequent use of independent check samples was made, along with standard reference materials obtained from various government agencies. All IBPES activity was documented in the QA/QC log kept for that purpose. NETL also submitted blind performance evaluation samples to the subcontractor periodically.

\section{Audits/Assessments from External Agencies}

An audit was a review of all procedures used in laboratory operations to assure compliance with the written QA/QC plan and written analytical SOPs. There were three types of audits performed: 


\section{System Audit}

A comprehensive review of one analytical method (or a group of closely related methods) over a specific time period (one to three months at the discretion of the QA/QC officer). The following areas were part of a system audit:

- A review of the analytical results reported during the chosen time period.

- An interview with the analyst regarding pertinent analytical SOPs.

- A review of analytical run logs for the chosen time period.

- A review of calibration data over the same time period including the source and make-up of the calibrates.

- A review of QC data acquired (duplicates, spikes, blanks, and spike duplicates) for that time period.

- A review of the group's QC log to evaluate the documentation and corrective action taken of any out-of-control events for the method in question.

- A review of any and all instrument maintenance logs for instruments used in the analysis.

- An assessment of how easily the above documentation was retrieved.

The QA/QC office was required to conduct a system audit of each method or method group at a minimum of once every six moths.

\section{Case Audit}

This consisted of following a single sample or set of samples through the entire analytical process, from sample intake and log-in to the final report. There was no minimum number of case audits required in a given time period, and audits were conducted at the QA/QC officer's discretion.

\section{Client and/or Third Party Audits}

The subcontractor was audited by professionals representing both regulatory agencies and clients. Recent audits include

- West Virginia Department of Public Health - for West Virginia certification to perform drinking water analyses.

- West Virginia Division of Environmental Protection - for West Virginia NPDES certification.

- United States Department of Agriculture - for a federal permit to import foreign soil. 


\section{Abbreviations and Acronyms}

\begin{tabular}{|c|c|c|c|}
\hline $\mathbf{A A} / \mathbf{R C}$ & $\begin{array}{l}\text { asbestos abatement/removal } \\
\text { contractor }\end{array}$ & ISMS & $\begin{array}{l}\text { integrated safety management } \\
\text { system }\end{array}$ \\
\hline ACHD & $\begin{array}{l}\text { Allegheny County (PA) Health } \\
\text { Department }\end{array}$ & $\begin{array}{l}\text { LWHT } \\
\text { MCL }\end{array}$ & $\begin{array}{l}\text { laboratory waste holding tank } \\
\text { maximum contaminant level }\end{array}$ \\
\hline ACM & asbestos-containing materials & MGN & NETL'S site at Morgantown, WV \\
\hline AEA & Atomic Energy Act & MSDS & material safety data sheet \\
\hline BTEX & $\begin{array}{l}\text { benzene, toluene, ethyl } \\
\text { benzene, and xylenes }\end{array}$ & $\begin{array}{l}\text { MUB } \\
\text { NEPA }\end{array}$ & $\begin{array}{l}\text { Morgantown Utility Board } \\
\text { National Environmental Policy Act }\end{array}$ \\
\hline $\begin{array}{l}\text { BOD } \\
\text { CAA }\end{array}$ & $\begin{array}{l}\text { biological oxygen demand } \\
\text { Clean Air Act }\end{array}$ & NESHAP & $\begin{array}{l}\text { National Emission Standards for } \\
\text { Hazardous Air Pollutants }\end{array}$ \\
\hline CERCLA & $\begin{array}{l}\text { Comprehensive Environmental } \\
\text { Response, Compensation and }\end{array}$ & NETL & $\begin{array}{l}\text { National Energy Technology } \\
\text { Laboratory }\end{array}$ \\
\hline CFC & $\begin{array}{l}\text { Liability Act } \\
\text { chlorofluorohydrocarbans }\end{array}$ & NIOSH & $\begin{array}{l}\text { National Institute for Occupational } \\
\text { Safety and Health }\end{array}$ \\
\hline $\begin{array}{l}\text { CFR } \\
\text { CLP }\end{array}$ & $\begin{array}{l}\text { U.S. Code of Federal Regulations } \\
\text { contract lab procedure }\end{array}$ & \multicolumn{2}{|c|}{$\begin{array}{l}\text { NOV Notice of Enforcement Action Letters of } \\
\text { Violation }\end{array}$} \\
\hline CPICOR & $\begin{array}{l}\text { clean power from integrated } \\
\text { coal/ore reduction }\end{array}$ & NPDES & $\begin{array}{l}\text { National Pollutant Discharge } \\
\text { Elimination System }\end{array}$ \\
\hline CWA & Clean Water Act & NPL & national priority list \\
\hline DOE & U.S. Department of Energy & NRC & Nuclear Regulatory Commission \\
\hline DOT & Department of Transportation & \multicolumn{2}{|c|}{ OAQWV Office of Air Quality } \\
\hline EA & environmental assessment & OSHA & U.S. Occupational Safety and \\
\hline $\begin{array}{l}\text { EIS } \\
\text { EMS }\end{array}$ & $\begin{array}{l}\text { environmental impact statement } \\
\text { Environmental Management System }\end{array}$ & PaDEP & $\begin{array}{l}\text { Health Administration } \\
\text { Pennsylvania Department of }\end{array}$ \\
\hline EPA & Environmental Protection Agency & & Environmental Protection \\
\hline EPCRA & $\begin{array}{l}\text { Emergency Planning and } \\
\text { Community Right-to-Know Act }\end{array}$ & $\begin{array}{l}\text { PA } \\
\text { PCB }\end{array}$ & $\begin{array}{l}\text { preliminary assessment } \\
\text { polychlorinated biphenyl }\end{array}$ \\
\hline ERO & emergency response organization & PDU & process development unit \\
\hline ESA & Endangered Species Act & PES & performance evaluation samples \\
\hline $\begin{array}{l}\text { ES\&H } \\
\text { FETC }\end{array}$ & $\begin{array}{l}\text { environment, safety, and health } \\
\text { Federal Energy Technology Center }\end{array}$ & PFBC & $\begin{array}{l}\text { Pennsylvania Fish and Boat } \\
\text { Commission }\end{array}$ \\
\hline FFCA & Federal Facilities Compliance Act & PGC & Pennsylvania Game Commission \\
\hline FIFRA & $\begin{array}{l}\text { Federal Insecticide, Fungicide, and } \\
\text { Rodenticide Act }\end{array}$ & $\begin{array}{l}\text { PGH } \\
\text { PHA }\end{array}$ & $\begin{array}{l}\text { NETL'S site at Pittsburgh, PA } \\
\text { Pleasant Hills (PA) Authority }\end{array}$ \\
\hline $\begin{array}{l}\text { FONSI } \\
\text { FWS }\end{array}$ & $\begin{array}{l}\text { Finding of No Significant Impact } \\
\text { Fish and Wildlife Service }\end{array}$ & PNDI & $\begin{array}{l}\text { Pennsylvania Natural Diversity } \\
\text { Inventory }\end{array}$ \\
\hline HP & horsepower & POTW & Publicly Owned Treatment Works \\
\hline HVAC & $\begin{array}{l}\text { heating, ventilation and air } \\
\text { conditioning }\end{array}$ & $\begin{array}{l}\text { QA } \\
\text { QC }\end{array}$ & $\begin{array}{l}\text { Quality Assurance } \\
\text { Quality Control }\end{array}$ \\
\hline IBPES & $\begin{array}{l}\text { international blind performance } \\
\text { evaluation samples } \\
\text { integrated safety management }\end{array}$ & $\begin{array}{l}\text { R\&Dresear } \\
\text { RCRA }\end{array}$ & $\begin{array}{l}\text { ch and development } \\
\text { Resource Conservation and } \\
\text { Recovery Act }\end{array}$ \\
\hline
\end{tabular}




$\begin{array}{ll}\text { SARA } & \begin{array}{l}\text { Superfund Amendments and } \\ \text { Reauthorization Act }\end{array} \\ \text { SDWA } & \begin{array}{l}\text { Safe Drinking Water Act } \\ \text { safety and analysis review }\end{array} \\ \text { SAR } & \begin{array}{l}\text { safety and analysis review system } \\ \text { SARS }\end{array} \\ \text { SEA } & \text { site evaluation accomplished } \\ \text { SERC } & \text { State Emergency Response } \\ & \text { Commission } \\ \text { SOPs } & \text { Standard Operating Procedures } \\ \text { TPQ } & \text { threshold planning quantity } \\ \text { TRI } & \text { toxic release inventory } \\ \text { TSCA } & \text { Toxic Substances Control Act } \\ \text { TSS } & \text { total suspended solids } \\ \text { TVA } & \text { Tennessee Valley Authority } \\ \text { WDEQ } & \text { Wyoming Department of } \\ & \text { Environmental Quality } \\ \text { WVDEP } & \text { West Virginia Department of } \\ & \text { Environmental Protection } \\ \text { WVDNR } & \text { West Virginia Division of Natural } \\ & \text { Resources } \\ \text { WWTF } & \text { wastewater treatment facility }\end{array}$




\section{Appendix: Tables $7-24$}

Table 7. NETL 2000 National Pollutant Discharge

Elimination System Storm Water Analysis Results

\begin{tabular}{|l|c|c|c|c|}
\hline \multirow{2}{*}{ Constituent } & \multicolumn{4}{c|}{ Sample Date } \\
\cline { 2 - 5 } & $2 / 23 / 00$ & $5 / 23 / 00$ & $9 / 23 / 00$ & $12 / 16 / 00$ \\
\hline \multicolumn{5}{|c|}{ North Outfall - PGH } \\
\hline Flow & $1.706 \mathrm{MGD}$ & $0.180 \mathrm{MGD}$ & $0.056 \mathrm{MGD}$ & $0.212 \mathrm{MGD}$ \\
\hline Suspended Solids & $83 \mathrm{mg} / \mathrm{L}$ & $<5 \mathrm{mg} / \mathrm{L}$ & $<1 \mathrm{mg} / \mathrm{L}$ & $3 \mathrm{mg} / \mathrm{L}$ \\
\hline CBOD5 & $<5 \mathrm{mg} / \mathrm{L}$ & $<5 \mathrm{mg} / \mathrm{L}$ & $2 \mathrm{mg} / \mathrm{L}$ & $2 \mathrm{mg} / \mathrm{L}$ \\
\hline Oil and Grease & $6 \mathrm{mg} / \mathrm{L}$ & $<5 \mathrm{mg} / \mathrm{L}$ & $<1 \mathrm{mg} / \mathrm{L}$ & $<1 \mathrm{mg} / \mathrm{L}$ \\
\hline Aluminum & $4.59 \mathrm{mg} / \mathrm{L}$ & $<0.1 \mathrm{mg} / \mathrm{L}$ & $<0.10 \mathrm{mg} / \mathrm{L}$ & $<0.10 \mathrm{mg} / \mathrm{L}$ \\
\hline Iron & $8.87 \mathrm{mg} / \mathrm{L}$ & $0.38 \mathrm{mg} / \mathrm{L}$ & $0.16 \mathrm{mg} / \mathrm{L}$ & $0.25 \mathrm{mg} / \mathrm{L}$ \\
\hline Manganese & $0.66 \mathrm{mg} / \mathrm{L}$ & $0.42 \mathrm{mg} / \mathrm{L}$ & $0.10 \mathrm{mg} / \mathrm{L}$ & $0.27 \mathrm{mg} / \mathrm{L}$ \\
\hline Lead & $60 \mathrm{Fg} / \mathrm{L}$ & $<50 \mathrm{Fg} / \mathrm{L}$ & $<100 \mathrm{Fg} / \mathrm{L}$ & $<100 \mathrm{Fg} / \mathrm{L}$ \\
\hline Mercury & $0.6 \mathrm{Fg} / \mathrm{L}$ & $<0.2 \mathrm{Fg} / \mathrm{L}$ & $<0.2 \mathrm{Fg} / \mathrm{L}$ & $<0.2 \mathrm{Fg} / \mathrm{L}$ \\
\hline pH & $6.74 \mathrm{s.u}$. & $7.51 \mathrm{s.u}$. & $8.11 \mathrm{s.u}$. & $7.77 \mathrm{s.u}$. \\
\hline Ammonia Nitrogen & $0.26 \mathrm{mg} / \mathrm{L}$ & $<0.05 \mathrm{mg} / \mathrm{L}$ & $0.29 \mathrm{mg} / \mathrm{L}$ & $0.14 \mathrm{mg} / \mathrm{L}$ \\
\hline & \multicolumn{5}{|c|}{ South Outfall - PGH } & \\
\hline Flow & $0.748 \mathrm{MGD}$ & $0.588 \mathrm{MGD}$ & $0.335 \mathrm{MGD}$ & $0.619 \mathrm{MGD}$ \\
\hline Suspended Solids & $104 \mathrm{mg} / \mathrm{L}$ & $61 \mathrm{mg} / \mathrm{L}$ & $33 \mathrm{mg} / \mathrm{L}$ & $13 \mathrm{mg} / \mathrm{L}$ \\
\hline Aluminum & $14.5 \mathrm{mg} / \mathrm{L}$ & $2.10 \mathrm{mg} / \mathrm{L}$ & $2.98 \mathrm{mg} / \mathrm{L}$ & $1.61 \mathrm{mg} / \mathrm{L}$ \\
\hline Iron & $8.20 \mathrm{mg} / \mathrm{L}$ & $1.46 \mathrm{mg} / \mathrm{L}$ & $0.73 \mathrm{mg} / \mathrm{L}$ & $0.59 \mathrm{mg} / \mathrm{L}$ \\
\hline Manganese & $0.58 \mathrm{mg} / \mathrm{L}$ & $0.43 \mathrm{mg} / \mathrm{L}$ & $0.66 \mathrm{mg} / \mathrm{L}$ & $0.31 \mathrm{mg} / \mathrm{L}$ \\
\hline Lead & $<50 \mathrm{Fg} / \mathrm{L}$ & $<50 \mathrm{Fg} / \mathrm{L}$ & $<100 \mathrm{Fg} / \mathrm{L}$ & $<100 \mathrm{Fg} / \mathrm{L}$ \\
\hline pH & $6.95 \mathrm{~s} . \mathrm{u}$. & $7.60 \mathrm{~s} . \mathrm{u}$. & $7.74 \mathrm{~s} . \mathrm{u}$. & $7.51 \mathrm{~s} . \mathrm{u}$. \\
\hline Ammonia Nitrogen & $1.46 \mathrm{mg} / \mathrm{L}$ & $2.92 \mathrm{mg} / \mathrm{L}$ & $1.25 \mathrm{mg} / \mathrm{L}$ & $0.68 \mathrm{mg} / \mathrm{L}$ \\
\hline
\end{tabular}

MGD = millions of gallons per day; s.u. = standard units.

Table 7. NETL 2000 National Pollutant Discharge

Elimination System Storm Water Analysis Results

(continued)

\begin{tabular}{|l|c|c|c|}
\hline \multicolumn{4}{|c|}{ Outfalls - MGN } \\
\hline Constituents & Outfall 002 & Outfall 005 & Outfall 010 \\
\hline Nitrate + Nitrite Nitrogen & $1.2 \mathrm{mg} / \mathrm{L}$ & $0.80 \mathrm{mg} / \mathrm{L}$ & $\mathrm{NS}$ \\
(Grab) & $1.0 \mathrm{mg} / \mathrm{L}$ & $0.53 \mathrm{mg} / \mathrm{L}$ & $\mathrm{NS}$ \\
Ammonia Nitrogen & $<0.50 \mathrm{mg} / \mathrm{L}$ & $<0.50 \mathrm{mg} / \mathrm{L}$ & $<0.50 \mathrm{mg} / \mathrm{L}$ \\
(Grab) & $<0.50 \mathrm{mg} / \mathrm{L}$ & $<0.50 \mathrm{mg} / \mathrm{L}$ & $<0.50 \mathrm{mg} / \mathrm{L}$ \\
Fecal Coliform & $33,000 \mathrm{col} / 100 \mathrm{~mL}$ & $3,800 \mathrm{col} / 100 \mathrm{~mL}$ & $51,000 \mathrm{col} / 100 \mathrm{~mL}$ \\
(Grab) & $1,800 \mathrm{col} / 100 \mathrm{~mL}$ & $4,000 \mathrm{col} / 100 \mathrm{~mL}$ & $3,200 \mathrm{col} / 100 \mathrm{~mL}$ \\
Total Suspended Solids & $\mathrm{NS}$ & $180 \mathrm{mg} / \mathrm{L}$ & $\mathrm{NS}$ \\
(Grab) & $\mathrm{NS}$ & $14 \mathrm{mg} / \mathrm{L}$ & $\mathrm{NS}$ \\
& & & \\
\hline
\end{tabular}

NS $=$ Not Sampled 
Table 8. NETL-PGH 2000 Wastewater Effluent Analysis (mg/L)

\begin{tabular}{|c|c|c|c|c|c|c|c|c|c|c|c|c|c|}
\hline Constituent & Permit Limit & & & & & & & & & & & & \\
\hline & Sampling Date & $01 / 26 / 00$ & $02 / 23 / 00$ & $03 / 27 / 00$ & $04 / 26 / 00$ & $05 / 26 / 00$ & $06 / 27 / 00$ & $07 / 26 / 00$ & $08 / 30 / 00$ & $09 / 27 / 00 \mathrm{r}$ & $10 / 25 / 00$ & $11 / 29 / 00$ & $12 / 27 / 00$ \\
\hline \multicolumn{14}{|c|}{ Building 74 Wastewater Treatment Facility Effluent } \\
\hline Aluminum & None & 0.15 & 0.21 & 0.18 & $<0.10$ & $<0.10$ & $<0.10$ & $<0.10$ & $<0.10$ & $<0.10$ & 0.27 & $<0.10$ & $<0.10$ \\
\hline Cadmium & None & $<0.005$ & $<0.005$ & $<0.005$ & $<0.005$ & $<0.005$ & $<0.005$ & $<0.005$ & $<0.005$ & $<0.005$ & $<0.005$ & $<0.005$ & $<0.005$ \\
\hline Chromium & None & $<0.01$ & 0.06 & $<0.01$ & $<0.01$ & $<0.01$ & $<0.01$ & $<0.01$ & $<0.01$ & $<0.01$ & $<0.01$ & $<0.01$ & $<0.01$ \\
\hline Copper & 0.08 & 0.04 & 0.12 & 0.03 & 0.04 & $<0.01$ & $<0.01$ & $<0.01$ & $<0.01$ & $<0.01$ & 0.08 & $<0.01$ & $<0.01$ \\
\hline Cyanide & $<0.005$ & $<0.001$ & 0.007 & 0.005 & $<0.001$ & 0.002 & 0.002 & $<0.001$ & $<0.001$ & $<0.001$ & $<0.001$ & $<0.001$ & 0.009 \\
\hline TOX & None & 0.067 & 0.070 & 0.074 & 0.038 & 0.047 & $<0.020$ & $<0.020$ & $<0.020$ & $<0.020$ & $<0.020$ & $<0.020$ & $<0.020$ \\
\hline Iron & None & 2.22 & 2.98 & 2.15 & 1.44 & 0.64 & $<0.01$ & 0.18 & 0.06 & 0.08 & 0.61 & 0.04 & 0.02 \\
\hline Lead & None & $<0.10$ & $<0.10$ & $<0.10$ & $<0.10$ & $<0.10$ & $<0.10$ & $<0.10$ & $<0.010$ & $<0.10$ & $<0.10$ & $<0.10$ & $<0.10$ \\
\hline Mercury & $<0.0002$ & 0.0003 & 0.0006 & $<0.0002$ & $<0.0002$ & $<0.0002$ & $<0.0002$ & $<0.0002$ & $<0.0002$ & $<0.0002$ & $<0.0002$ & $<0.0002$ & $<0.0002$ \\
\hline Nickel & None & $<0.01$ & $<0.01$ & $<0.01$ & 0.03 & 0.02 & $<0.01$ & 0.01 & $<0.01$ & $<0.01$ & $<0.01$ & $<0.01$ & $<0.01$ \\
\hline Oil \& Grease & None & $<1$ & $<1$ & 1 & 1 & 1 & $<1$ & $<1$ & 3 & 4 & $<1$ & 2 & $<1$ \\
\hline $\mathrm{pH}$ (s.u.) & $6.0-9.0$ & 7.3 & 7.2 & 8.1 & 6.8 & 7.6 & 8.1 & 7.9 & 8.0 & 7.8 & 8.0 & 8.4 & 8.2 \\
\hline Phenolics & 0.025 & 0.010 & 0.008 & 0.006 & $<0.001$ & $<0.001$ & $<0.001$ & 0.003 & 0.004 & $<0.001$ & 0.002 & 0.001 & 0.002 \\
\hline TSS & None & 10 & 13 & 6 & 5 & 2 & $<1$ & 2 & $<1$ & $<1$ & $<1$ & $<1$ & $<1$ \\
\hline $\operatorname{Tin}$ & None & $<0.10$ & $<0.10$ & $<0.10$ & $<0.10$ & $<0.10$ & $<0.10$ & $<0.10$ & $<0.10$ & $<0.10$ & $<0.10$ & $<0.10$ & $<0.10$ \\
\hline Trichloromethane & $<0.005$ & $<0.005$ & $<0.005$ & $<0.005$ & $<0.005$ & $<0.005$ & $<0.005$ & $<0.005$ & $<0.005$ & $<0.005$ & $<0.005$ & $<0.005$ & $<0.005$ \\
\hline Zinc & None & 0.16 & 0.35 & 0.04 & 0.07 & 0.04 & 0.05 & 0.01 & $<0.01$ & 0.01 & 0.12 & $<0.01$ & $<0.01$ \\
\hline
\end{tabular}

NS = not sampled; TOX = total organic halide; TSS = total suspended solids; s. U = standard units.

Standard/Guideline - Pleasant Hills Authority Industrial Sewer Use Paermit, December 22, 1999.

$$
\begin{aligned}
& \text { Value exceeded } \\
& \text { Permit Limits }
\end{aligned}
$$


Table 8. NETL-MGN 2000 Wastewater Effluent Analysis (lb/d)

(continued)

\begin{tabular}{|c|c|c|c|c|c|c|c|c|c|c|c|c|c|}
\hline Parameter & Limit & January & February & March & April & May & June & July & August & September & October & November & December \\
\hline $\begin{array}{c}\text { Flow (MGD) Monthly Average } \\
\text { Daily Maximum }\end{array}$ & $\begin{array}{l}0.09 \\
0.15\end{array}$ & $\begin{array}{c}0.004 \\
0.01\end{array}$ & $\begin{array}{l}0.007 \\
0.03\end{array}$ & $\begin{array}{l}0.009 \\
0.02\end{array}$ & $\begin{array}{l}0.01 \\
0.02\end{array}$ & $\begin{array}{l}0.01 \\
0.02\end{array}$ & $\begin{array}{l}0.01 \\
0.02\end{array}$ & $\begin{array}{l}0.01 \\
0.02\end{array}$ & $\begin{array}{c}0.009 \\
0.09\end{array}$ & $\begin{array}{c}0.005 \\
0.03\end{array}$ & $\begin{array}{c}0.004 \\
0.13\end{array}$ & $\begin{array}{c}0.009 \\
0.12\end{array}$ & $\begin{array}{l}0.02 \\
0.08\end{array}$ \\
\hline $\begin{array}{l}\text { Monthly Average } \\
\text { Daily Maximum }\end{array}$ & $\begin{array}{l}\text { None } \\
\text { None }\end{array}$ & $\begin{array}{l}0.2 \\
0.6\end{array}$ & $\begin{array}{l}1 \\
6\end{array}$ & $\begin{array}{c}7 \\
16\end{array}$ & $\begin{array}{l}0.3 \\
0.5\end{array}$ & $\begin{array}{l}1.84 \\
3.51\end{array}$ & $\begin{array}{l}0.44 \\
0.88\end{array}$ & $\begin{array}{l}\text { ND } \\
\text { ND }\end{array}$ & $\begin{array}{l}0.25 \\
0.55\end{array}$ & $\begin{array}{l}0.16 \\
0.98\end{array}$ & $\begin{array}{c}0.31 \\
10.09\end{array}$ & $\begin{array}{c}0.24 \\
3.2\end{array}$ & $\begin{array}{l}\text { ND } \\
\text { ND }\end{array}$ \\
\hline $\begin{array}{l}\text { Monthly Average } \\
\text { Daily Maximum }\end{array}$ & $\begin{array}{l}\text { None } \\
\text { None }\end{array}$ & $\begin{array}{l}0.3 \\
0.7\end{array}$ & $\begin{array}{l}0.4 \\
1.8\end{array}$ & $\begin{array}{l}1.7 \\
3.7\end{array}$ & $\begin{array}{l}2.5 \\
5\end{array}$ & $\begin{array}{l}3.7 \\
7\end{array}$ & $\begin{array}{l}0.42 \\
0.84\end{array}$ & $\begin{array}{l}1 \\
2\end{array}$ & $\begin{array}{l}0.75 \\
1.67\end{array}$ & $\begin{array}{l}0.25 \\
1.5\end{array}$ & $\begin{array}{l}0.27 \\
8.68\end{array}$ & $\begin{array}{l}1.2 \\
16\end{array}$ & $\begin{array}{l}0.8 \\
3.3\end{array}$ \\
\hline $\begin{array}{l}\text { Monthly Average } \\
\text { Daily Maximum }\end{array}$ & $\begin{array}{l}0.005 \\
0.008\end{array}$ & $\begin{array}{l}\mathrm{ND} \\
\mathrm{ND}\end{array}$ & $\begin{array}{l}\text { ND } \\
\text { ND }\end{array}$ & $\begin{array}{l}\text { ND } \\
\text { ND }\end{array}$ & $\begin{array}{l}\text { ND } \\
\text { ND }\end{array}$ & $\begin{array}{l}\text { ND } \\
\text { ND }\end{array}$ & $\begin{array}{l}\text { ND } \\
\text { ND }\end{array}$ & $\begin{array}{l}\text { ND } \\
\text { ND }\end{array}$ & $\begin{array}{l}\text { ND } \\
\text { ND }\end{array}$ & $\begin{array}{l}\text { ND } \\
\text { ND }\end{array}$ & $\begin{array}{l}\text { ND } \\
\text { ND }\end{array}$ & $\begin{array}{l}\text { ND } \\
\text { ND }\end{array}$ & $\begin{array}{l}\text { ND } \\
\text { ND }\end{array}$ \\
\hline $\begin{array}{|cc|}\text { Cadmium } & \begin{array}{c}\text { Monthly Average } \\
\text { Daily Maximum }\end{array} \\
\end{array}$ & $\begin{array}{l}\text { None } \\
\text { None }\end{array}$ & $\begin{array}{l}\text { ND } \\
\text { ND }\end{array}$ & $\begin{array}{l}\mathrm{ND} \\
\mathrm{ND}\end{array}$ & $\begin{array}{l}\text { ND } \\
\text { ND }\end{array}$ & $\begin{array}{l}\text { ND } \\
\text { ND }\end{array}$ & $\begin{array}{l}\text { ND } \\
\text { ND }\end{array}$ & $\begin{array}{l}\text { ND } \\
\text { ND }\end{array}$ & $\begin{array}{l}\text { ND } \\
\text { ND }\end{array}$ & $\begin{array}{l}\text { ND } \\
\text { ND }\end{array}$ & $\begin{array}{l}\text { ND } \\
\text { ND }\end{array}$ & $\begin{array}{l}\text { ND } \\
\text { ND }\end{array}$ & $\begin{array}{l}\text { ND } \\
\text { ND }\end{array}$ & $\begin{array}{l}\text { ND } \\
\text { ND }\end{array}$ \\
\hline $\begin{array}{c}\text { Chromium Monthly Average } \\
\text { Daily Maximum }\end{array}$ & $\begin{array}{l}0.007 \\
0.011\end{array}$ & $\begin{array}{l}\text { ND } \\
\text { ND }\end{array}$ & $\begin{array}{l}\text { ND } \\
\text { ND }\end{array}$ & $\begin{array}{l}\text { ND } \\
\text { ND }\end{array}$ & $\begin{array}{l}\text { ND } \\
\text { ND }\end{array}$ & $\begin{array}{l}0.005 \\
0.004\end{array}$ & $\begin{array}{l}\text { ND } \\
\text { ND }\end{array}$ & $\begin{array}{l}\text { ND } \\
\text { ND }\end{array}$ & $\begin{array}{l}\text { ND } \\
\text { ND }\end{array}$ & $\begin{array}{l}\text { ND } \\
\text { ND }\end{array}$ & $\begin{array}{l}\text { ND } \\
\text { ND }\end{array}$ & $\begin{array}{l}\text { ND } \\
\text { ND }\end{array}$ & $\begin{array}{l}\text { ND } \\
\text { ND }\end{array}$ \\
\hline $\begin{array}{l}\text { Monthly Average } \\
\text { Daily Maximum }\end{array}$ & $\begin{array}{l}0.04 \\
0.06\end{array}$ & $\begin{array}{c}0.00094 \\
0.0023 \\
\end{array}$ & $\begin{array}{l}0.0014 \\
0.006 \\
\end{array}$ & $\begin{array}{l}0.003 \\
0.0067 \\
\end{array}$ & $\begin{array}{l}0.0009 \\
0.0018 \\
\end{array}$ & $\begin{array}{l}0.0014 \\
0.0026\end{array}$ & $\begin{array}{l}0.0015 \\
0.003 \\
\end{array}$ & $\begin{array}{l}0.0007 \\
0.0014\end{array}$ & $\begin{array}{l}0.0011 \\
0.0023 \\
\end{array}$ & $\begin{array}{l}0.0013 \\
0.0075\end{array}$ & $\begin{array}{l}0.0007 \\
0.0228 \\
\end{array}$ & $\begin{array}{l}0.004 \\
0.048 \\
\end{array}$ & $\begin{array}{l}0.001 \\
0.004\end{array}$ \\
\hline \begin{tabular}{|ll} 
Cyanide & $\begin{array}{l}\text { Monthly Average } \\
\text { Daily Maximum }\end{array}$ \\
\end{tabular} & $\begin{array}{l}0.02 \\
0.03 \\
\end{array}$ & $\begin{array}{l}\text { ND } \\
\text { ND }\end{array}$ & $\begin{array}{l}\text { ND } \\
\text { ND }\end{array}$ & $\begin{array}{l}N D \\
N D\end{array}$ & $\begin{array}{l}\text { ND } \\
\text { ND }\end{array}$ & $\begin{array}{l}\text { ND } \\
\text { ND }\end{array}$ & $\begin{array}{l}\text { ND } \\
\text { ND }\end{array}$ & $\begin{array}{l}\text { ND } \\
\text { ND }\end{array}$ & $\begin{array}{l}\text { ND } \\
\text { ND }\end{array}$ & $\begin{array}{l}\text { ND } \\
\text { ND }\end{array}$ & $\begin{array}{l}\text { ND } \\
\text { ND }\end{array}$ & $\begin{array}{l}\text { ND } \\
\text { ND }\end{array}$ & $\begin{array}{l}\text { ND } \\
\text { ND }\end{array}$ \\
\hline $\begin{array}{l}\text { Monthly Average } \\
\text { Daily Maximum }\end{array}$ & $\begin{array}{l}0.025 \\
0.038\end{array}$ & $\begin{array}{l}0.00018 \\
0.00045\end{array}$ & $\begin{array}{l}0.0006 \\
0.0025\end{array}$ & $\begin{array}{l}0.0006 \\
0.0013\end{array}$ & $\begin{array}{l}\text { ND } \\
\text { ND }\end{array}$ & $\begin{array}{l}\text { ND } \\
\text { ND }\end{array}$ & $\begin{array}{l}\text { ND } \\
\text { ND }\end{array}$ & $\begin{array}{l}\text { ND } \\
\text { ND }\end{array}$ & $\begin{array}{l}\text { ND } \\
\text { ND }\end{array}$ & $\begin{array}{l}\text { ND } \\
\text { ND }\end{array}$ & $\begin{array}{l}\text { ND } \\
\text { ND }\end{array}$ & $\begin{array}{l}0.0009 \\
0.012\end{array}$ & $\begin{array}{l}\text { ND } \\
\text { ND }\end{array}$ \\
\hline $\begin{array}{|cc|}\text { Mercury } & \begin{array}{c}\text { Monthly Average } \\
\text { Daily Maximum }\end{array} \\
\end{array}$ & $\begin{array}{l}0.0006 \\
0.0009 \\
\end{array}$ & $\begin{array}{l}\mathrm{ND} \\
\mathrm{ND} \\
\end{array}$ & $\begin{array}{l}\mathrm{ND} \\
\mathrm{ND} \\
\end{array}$ & $\begin{array}{l}0.00003 \\
0.0001 \\
\end{array}$ & $\begin{array}{l}\text { ND } \\
\text { ND }\end{array}$ & $\begin{array}{l}\mathrm{ND} \\
\mathrm{ND} \\
\end{array}$ & $\begin{array}{l}\text { ND } \\
\text { ND }\end{array}$ & $\begin{array}{l}\mathrm{ND} \\
\mathrm{ND} \\
\end{array}$ & $\begin{array}{l}\text { ND } \\
\text { ND }\end{array}$ & $\begin{array}{l}\text { ND } \\
\text { ND }\end{array}$ & $\begin{array}{l}\text { ND } \\
\text { ND }\end{array}$ & $\begin{array}{l}\mathrm{ND} \\
\mathrm{ND}\end{array}$ & $\begin{array}{l}\text { ND } \\
\text { ND }\end{array}$ \\
\hline $\begin{array}{l}\text { Monthly Average } \\
\text { Daily Maximum }\end{array}$ & $\begin{array}{l}0.01 \\
0.015\end{array}$ & $\begin{array}{l}\text { ND } \\
\text { ND }\end{array}$ & $\begin{array}{l}0.0005 \\
0.002\end{array}$ & $\begin{array}{l}\text { ND } \\
\text { ND }\end{array}$ & $\begin{array}{l}\text { ND } \\
\text { ND }\end{array}$ & $\begin{array}{l}\text { ND } \\
\text { ND }\end{array}$ & $\begin{array}{l}0.0005 \\
0.0009 \\
\end{array}$ & $\begin{array}{l}\text { ND } \\
\text { ND }\end{array}$ & $\begin{array}{l}\text { ND } \\
\text { ND }\end{array}$ & $\begin{array}{l}\text { ND } \\
\text { ND }\end{array}$ & $\begin{array}{l}0.0002 \\
0.0057\end{array}$ & $\begin{array}{l}\text { ND } \\
\text { ND }\end{array}$ & $\begin{array}{l}\text { ND } \\
\text { ND }\end{array}$ \\
\hline $\begin{array}{l}\text { Monthly Average } \\
\text { Daily Maximum }\end{array}$ & $\begin{array}{l}0.011 \\
0.017\end{array}$ & $\begin{array}{l}\text { ND } \\
\text { ND }\end{array}$ & $\begin{array}{l}\text { ND } \\
\text { ND }\end{array}$ & $\begin{array}{l}0.0014 \\
0.003\end{array}$ & $\begin{array}{l}\text { ND } \\
\text { ND }\end{array}$ & $\begin{array}{l}\text { ND } \\
\text { ND }\end{array}$ & $\begin{array}{l}0.0007 \\
0.0014\end{array}$ & $\begin{array}{l}\text { ND } \\
\text { ND }\end{array}$ & $\begin{array}{l}\text { ND } \\
\text { ND }\end{array}$ & $\begin{array}{l}0.0003 \\
0.0015\end{array}$ & $\begin{array}{c}0.0004 \\
0.012\end{array}$ & $\begin{array}{l}\text { ND } \\
\text { ND }\end{array}$ & $\begin{array}{l}\text { ND } \\
\text { ND }\end{array}$ \\
\hline $\begin{array}{l}\text { Monthly Average } \\
\text { Daily Maximum } \\
\end{array}$ & $\begin{array}{l}0.2 \\
0.3 \\
\end{array}$ & $\begin{array}{c}0.004 \\
0.01 \\
\end{array}$ & $\begin{array}{l}0.009 \\
0.04 \\
\end{array}$ & $\begin{array}{l}0.0195 \\
0.043 \\
\end{array}$ & $\begin{array}{l}0.0167 \\
0.0334 \\
\end{array}$ & $\begin{array}{l}0.0147 \\
0.028 \\
\end{array}$ & \begin{tabular}{|l|}
0.0175 \\
0.0351 \\
\end{tabular} & $\begin{array}{l}0.0117 \\
0.0234 \\
\end{array}$ & $\begin{array}{c}0.0063 \\
0.014 \\
\end{array}$ & $\begin{array}{l}0.0092 \\
0.0551 \\
\end{array}$ & $\begin{array}{l}0.0033 \\
0.1084 \\
\end{array}$ & $\begin{array}{l}0.006 \\
0.085 \\
\end{array}$ & $\begin{array}{l}0.006 \\
0.025 \\
\end{array}$ \\
\hline $\begin{array}{l}\text { Monthly Average } \\
\text { Daily Maximum }\end{array}$ & $\begin{array}{l}\text { None } \\
\text { None }\end{array}$ & $\begin{array}{c}0.02 \\
0.049\end{array}$ & $\begin{array}{c}0.05 \\
0.215\end{array}$ & $\begin{array}{l}0.113 \\
0.25\end{array}$ & $\begin{array}{l}0.084 \\
0.167\end{array}$ & $\begin{array}{c}0.073 \\
0.14\end{array}$ & $\begin{array}{l}0.073 \\
0.147\end{array}$ & $\begin{array}{l}0.031 \\
0.062\end{array}$ & $\begin{array}{l}0.024 \\
0.053\end{array}$ & $\begin{array}{l}0.058 \\
0.351\end{array}$ & $\begin{array}{l}0.025 \\
0.803\end{array}$ & $\begin{array}{l}0.19 \\
2.5\end{array}$ & $\begin{array}{l}0.04 \\
0.15\end{array}$ \\
\hline $\begin{array}{c}\text { Manganese Monthly Average } \\
\text { Daily Maximum }\end{array}$ & $\begin{array}{l}\text { None } \\
\text { None }\end{array}$ & $\begin{array}{l}0.003 \\
0.0076\end{array}$ & $\begin{array}{l}0.01 \\
0.05\end{array}$ & $\begin{array}{l}0.033 \\
0.073 \\
\end{array}$ & $\begin{array}{l}0.008 \\
0.017 \\
\end{array}$ & $\begin{array}{l}0.015 \\
0.028 \\
\end{array}$ & $\begin{array}{l}0.01 \\
0.02\end{array}$ & $\begin{array}{l}0.006 \\
0.012 \\
\end{array}$ & $\begin{array}{l}0.004 \\
0.009 \\
\end{array}$ & $\begin{array}{l}0.013 \\
0.75 \\
\end{array}$ & $\begin{array}{l}0.004 \\
0.119 \\
\end{array}$ & $\begin{array}{c}0.008 \\
0.1 \\
\end{array}$ & $\begin{array}{l}0.006 \\
0.024 \\
\end{array}$ \\
\hline \begin{tabular}{|cc} 
Phenolics & $\begin{array}{l}\text { Monthly Average } \\
\text { Daily Maximum }\end{array}$ \\
\end{tabular} & $\begin{array}{l}\text { None } \\
\text { None }\end{array}$ & $\begin{array}{l}\text { ND } \\
\text { ND }\end{array}$ & $\begin{array}{l}\text { ND } \\
\text { ND }\end{array}$ & $\begin{array}{l}\text { ND } \\
\text { ND }\end{array}$ & $\begin{array}{l}\text { ND } \\
\text { ND }\end{array}$ & $\begin{array}{l}\text { ND } \\
\text { ND }\end{array}$ & $\begin{array}{l}\text { ND } \\
\text { ND }\end{array}$ & $\begin{array}{l}\text { ND } \\
\text { ND }\end{array}$ & $\begin{array}{l}\text { ND } \\
\text { ND }\end{array}$ & $\begin{array}{l}\text { ND } \\
\text { ND }\end{array}$ & $\begin{array}{l}\text { ND } \\
\text { ND }\end{array}$ & $\begin{array}{l}\text { ND } \\
\text { ND }\end{array}$ & $\begin{array}{l}\text { ND } \\
\text { ND }\end{array}$ \\
\hline $\begin{array}{c}\text { Total Organic Halogens } \\
\text { Monthly Average } \\
\text { Daily Maximum } \\
\end{array}$ & $\begin{array}{l}\text { None } \\
\text { None }\end{array}$ & $\begin{array}{l}0.0033 \\
0.0083 \\
\end{array}$ & $\begin{array}{l}0.0055 \\
0.024 \\
\end{array}$ & $\begin{array}{l}0.0038 \\
0.0083 \\
\end{array}$ & $\begin{array}{l}0.0077 \\
0.0154 \\
\end{array}$ & $\begin{array}{l}0.0082 \\
0.0156 \\
\end{array}$ & $\begin{array}{l}0.0073 \\
0.0145 \\
\end{array}$ & $\begin{array}{l}0.0078 \\
0.0157\end{array}$ & $\begin{array}{c}0.0063 \\
0.014 \\
\end{array}$ & $\begin{array}{c}0.0038 \\
0.023 \\
\end{array}$ & $\begin{array}{l}0.0028 \\
0.0911 \\
\end{array}$ & $\begin{array}{c}0.009 \\
0.12 \\
\end{array}$ & $\begin{array}{l}0.018 \\
0.073 \\
\end{array}$ \\
\hline $\begin{array}{|cc|}\text { Organics } & \begin{array}{c}\text { Monthly Average } \\
\text { Daily Maximum }\end{array} \\
\end{array}$ & $\begin{array}{l}\text { None } \\
\text { None }\end{array}$ & $\begin{array}{l}\text { NS } \\
\text { NS }\end{array}$ & $\begin{array}{l}\text { NS } \\
\text { NS }\end{array}$ & $\begin{array}{l}\text { NS } \\
\text { NS }\end{array}$ & $\begin{array}{l}\text { NS } \\
\text { NS }\end{array}$ & $\begin{array}{l}\text { NS } \\
\text { NS }\end{array}$ & $\begin{array}{l}\text { ND } \\
\text { ND }\end{array}$ & $\begin{array}{l}\text { NS } \\
\text { NS }\end{array}$ & $\begin{array}{l}\text { NS } \\
\text { NS } \\
\end{array}$ & $\begin{array}{l}\text { NS } \\
\text { NS }\end{array}$ & $\begin{array}{l}\text { NS } \\
\text { NS }\end{array}$ & $\begin{array}{l}\text { NS } \\
\text { NS } \\
\end{array}$ & $\begin{array}{l}\text { NS } \\
\text { NS }\end{array}$ \\
\hline $\begin{array}{ll}\text { pH (s.u.) } & \begin{array}{r}\text { Minimum } \\
\text { Maximum }\end{array}\end{array}$ & $\begin{array}{l}6.0 \\
9.0\end{array}$ & $\begin{array}{l}6.6 \\
7.5\end{array}$ & $\begin{array}{l}6.9 \\
8.0\end{array}$ & $\begin{array}{l}6.1 \\
7.7\end{array}$ & $\begin{array}{l}7.2 \\
7.8\end{array}$ & $\begin{array}{l}6.9 \\
8.0\end{array}$ & $\begin{array}{l}7.0 \\
8.0\end{array}$ & $\begin{array}{l}7.2 \\
8.0\end{array}$ & $\begin{array}{l}7.8 \\
8.5\end{array}$ & $\begin{array}{l}7.0 \\
8.3\end{array}$ & $\begin{array}{l}6.9 \\
8.2\end{array}$ & $\begin{array}{l}7.0 \\
8.2\end{array}$ & $\begin{array}{l}7.1 \\
7.5\end{array}$ \\
\hline
\end{tabular}


Table 9. NETL-PGH Industrial Sewer Use Permit Monitoring Analysis

\begin{tabular}{|c|c|c|c|c|c|c|}
\hline Constituent & Free Cyanide & Phenol & Copper & Mercury & Chloroform & $\mathrm{pH}$ \\
\hline Permit Limit & $<0.010 \mathrm{mg} / \mathrm{L}$ & $0.050 \mathrm{mg} / \mathrm{L}$ & $0.08 \mathrm{mg} / \mathrm{L}$ & $<0.002 \mathrm{mg} / \mathrm{L}$ & $<10 \mathrm{ug} / \mathrm{L}$ & $6.0-9.0$ s.u. \\
\hline \multicolumn{7}{|c|}{ April 26, 2000 Sampling Date } \\
\hline \multicolumn{7}{|c|}{ Subinterceptor Location } \\
\hline Composite & $\mathrm{N} / \mathrm{A}$ & $\mathrm{N} / \mathrm{A}$ & $0.06 \mathrm{mg} / \mathrm{L}$ & $<0.0002 \mathrm{mg} / \mathrm{L}$ & $\mathrm{N} / \mathrm{A}$ & $\mathrm{N} / \mathrm{A}$ \\
\hline Grab \#1 & $<0.001 \mathrm{mg} / \mathrm{L}$ & $0.022 \mathrm{mg} / \mathrm{L}$ & $\mathrm{N} / \mathrm{A}$ & $\mathrm{N} / \mathrm{A}$ & $<5 \mathrm{Fg} / \mathrm{L}$ & 7.42 s.u. \\
\hline Grab \#2 & $<0.001 \mathrm{mg} / \mathrm{L}$ & $0.014 \mathrm{mg} / \mathrm{L}$ & $\mathrm{N} / \mathrm{A}$ & $\mathrm{N} / \mathrm{A}$ & $<5 \mathrm{Fg} / \mathrm{L}$ & 7.77 s.u. \\
\hline Grab \#3 & $0.005 \mathrm{mg} / \mathrm{L}$ & $0.083 \mathrm{mg} / \mathrm{L}$ & $\mathrm{N} / \mathrm{A}$ & $\mathrm{N} / \mathrm{A}$ & $<5 \mathrm{Fg} / \mathrm{L}$ & 8.06 s.u. \\
\hline Grab \#4 & $<0.001 \mathrm{mg} / \mathrm{L}$ & $0.025 \mathrm{mg} / \mathrm{L}$ & $\mathrm{N} / \mathrm{A}$ & $\mathrm{N} / \mathrm{A}$ & $<5 \mathrm{Fg} / \mathrm{L}$ & 7.88 s.u. \\
\hline \multicolumn{7}{|l|}{ Building 74 Effluent } \\
\hline Composite & $\mathrm{N} / \mathrm{A}$ & $\mathrm{N} / \mathrm{A}$ & $<0.01 \mathrm{mg} / \mathrm{L}$ & $<0.0002 \mathrm{mg} / \mathrm{L}$ & $\mathrm{N} / \mathrm{A}$ & $\mathrm{N} / \mathrm{A}$ \\
\hline Grab \#1 & $<0.001 \mathrm{mg} / \mathrm{L}$ & $0.004 \mathrm{mg} / \mathrm{L}$ & $\mathrm{N} / \mathrm{A}$ & $\mathrm{N} / \mathrm{A}$ & $<5 \mathrm{Fg} / \mathrm{L}$ & 7.30 s.u. \\
\hline Grab \#2 & $<0.001 \mathrm{mg} / \mathrm{L}$ & $<0.001$ & $\mathrm{~N} / \mathrm{A}$ & $\mathrm{N} / \mathrm{A}$ & $<5 \mathrm{Fg} / \mathrm{L}$ & 7.57 s.u. \\
\hline Grab \#3 & $<0.001 \mathrm{mg} / \mathrm{L}$ & $0.004 \mathrm{mg} / \mathrm{L}$ & $\mathrm{N} / \mathrm{A}$ & $\mathrm{N} / \mathrm{A}$ & $<5 \mathrm{Fg} / \mathrm{L}$ & 8.18 s.u. \\
\hline Grab \#4 & $<0.001 \mathrm{mg} / \mathrm{L}$ & $<0.001 \mathrm{mg} / \mathrm{L}$ & $\mathrm{N} / \mathrm{A}$ & $\mathrm{N} / \mathrm{A}$ & $<5 \mathrm{Fg} / \mathrm{L}$ & 8.71 s.u. \\
\hline \multicolumn{7}{|c|}{ Building 141 Sanitary Manhole } \\
\hline Composite & $\mathrm{N} / \mathrm{A}$ & $\mathrm{N} / \mathrm{A}$ & $0.05 \mathrm{mg} / \mathrm{L}$ & $<0.0002 \mathrm{mg} / \mathrm{L}$ & $\mathrm{N} / \mathrm{A}$ & $\mathrm{N} / \mathrm{A}$ \\
\hline Grab \#1 & $0.002 \mathrm{mg} / \mathrm{L}$ & $0.007 \mathrm{mg} / \mathrm{L}$ & $\mathrm{N} / \mathrm{A}$ & $\mathrm{N} / \mathrm{A}$ & $11 \mathrm{Fg} / \mathrm{L}$ & 7.05 s.u. \\
\hline Grab \#2 & $0.008 \mathrm{mg} / \mathrm{L}$ & $0.006 \mathrm{mg} / \mathrm{L}$ & $\mathrm{N} / \mathrm{A}$ & $\mathrm{N} / \mathrm{A}$ & $11 \mathrm{Fg} / \mathrm{L}$ & 7.45 s.u. \\
\hline Grab \#3 & $0.007 \mathrm{mg} / \mathrm{L}$ & $0.018 \mathrm{mg} / \mathrm{L}$ & $\mathrm{N} / \mathrm{A}$ & $\mathrm{N} / \mathrm{A}$ & $11 \mathrm{Fg} / \mathrm{L}$ & 7.52 s.u. \\
\hline Grab \#4 & $0.004 \mathrm{mg} / \mathrm{L}$ & $0.002 \mathrm{mg} / \mathrm{L}$ & $\mathrm{N} / \mathrm{A}$ & $\mathrm{N} / \mathrm{A}$ & $10 \mathrm{Fg} / \mathrm{L}$ & 6.58 s.u. \\
\hline \multicolumn{7}{|c|}{ October 24, 2000 Sample Date } \\
\hline \multicolumn{7}{|c|}{ Subinterceptor Location } \\
\hline Composite & $\mathrm{N} / \mathrm{A}$ & $\mathrm{N} / \mathrm{A}$ & $0.08 \mathrm{mg} / \mathrm{L}$ & $<0.0002 \mathrm{mg} / \mathrm{L}$ & $\mathrm{N} / \mathrm{A}$ & $\mathrm{N} / \mathrm{A}$ \\
\hline Grab \#1 & $0.016 \mathrm{mg} / \mathrm{L}$ & $0.026 \mathrm{mg} / \mathrm{L}$ & $\mathrm{N} / \mathrm{A}$ & $\mathrm{N} / \mathrm{A}$ & $<5 \mathrm{Fg} / \mathrm{L}$ & 7.63 s.u. \\
\hline Grab \#2 & $0.007 \mathrm{mg} / \mathrm{L}$ & $0.019 \mathrm{mg} / \mathrm{L}$ & $\mathrm{N} / \mathrm{A}$ & $\mathrm{N} / \mathrm{A}$ & $7 \mathrm{Fg} / \mathrm{L}$ & 7.39 s.u. \\
\hline Grab \#3 & $0.007 \mathrm{mg} / \mathrm{L}$ & $0.021 \mathrm{mg} / \mathrm{L}$ & $\mathrm{N} / \mathrm{A}$ & $\mathrm{N} / \mathrm{A}$ & $<5 \mathrm{Fg} / \mathrm{L}$ & 7.75 s.u. \\
\hline Grab \#4 & $0.005 \mathrm{mg} / \mathrm{L}$ & $0.019 \mathrm{mg} / \mathrm{L}$ & $\mathrm{N} / \mathrm{A}$ & $\mathrm{N} / \mathrm{A}$ & $8 \mathrm{Fg} / \mathrm{L}$ & 7.76 s.u. \\
\hline \multicolumn{7}{|l|}{ Building 74 Effluent } \\
\hline Composite & $\mathrm{N} / \mathrm{A}$ & $\mathrm{N} / \mathrm{A}$ & $<0.01 \mathrm{mg} / \mathrm{L}$ & $<0.0002 \mathrm{mg} / \mathrm{L}$ & $\mathrm{N} / \mathrm{A}$ & $\mathrm{N} / \mathrm{A}$ \\
\hline Grab \#1 & $<0.001 \mathrm{mg} / \mathrm{L}$ & $0.002 \mathrm{mg} / \mathrm{L}$ & $\mathrm{N} / \mathrm{A}$ & $\mathrm{N} / \mathrm{A}$ & $<5 \mathrm{Fg} / \mathrm{L}$ & 7.39 s.u. \\
\hline Grab \#2 & $<0.001 \mathrm{mg} / \mathrm{L}$ & $0.002 \mathrm{mg} / \mathrm{L}$ & $\mathrm{N} / \mathrm{A}$ & $\mathrm{N} / \mathrm{A}$ & $<5 \mathrm{Fg} / \mathrm{L}$ & 8.58 s.u. \\
\hline Grab \#3 & $<0.001 \mathrm{mg} / \mathrm{L}$ & $0.002 \mathrm{mg} / \mathrm{L}$ & $\mathrm{N} / \mathrm{A}$ & $\mathrm{N} / \mathrm{A}$ & $<5 \mathrm{Fg} / \mathrm{L}$ & 8.59 s.u. \\
\hline Grab \#4 & $<0.001 \mathrm{mg} / \mathrm{L}$ & $0.002 \mathrm{mg} / \mathrm{L}$ & $\mathrm{N} / \mathrm{A}$ & $\mathrm{N} / \mathrm{A}$ & $<5 \mathrm{Fg} / \mathrm{L}$ & 8.33 s.u. \\
\hline
\end{tabular}

$\mathrm{ND}=$ not detected; s.u. = standard units; $\mathrm{mg} / \mathrm{L}=$ milligrams per liter; $\mathrm{Fg} / \mathrm{L}=$ micrograms per liter; 
Table 10. NETL-PGH 2000 Groundwater Detection Monitoring Program Results of Analysis - Groundwater Samples, Main Plateau - Contamination Indicator Constituents

\begin{tabular}{|c|c|c|c|c|c|c|c|c|c|c|c|c|c|c|c|c|}
\hline & \multirow{3}{*}{$\begin{array}{l}\text { Constituents } \\
\\
\text { Sample Event }\end{array}$} & \multicolumn{15}{|c|}{ Well } \\
\hline & & \multicolumn{2}{|c|}{ MPW-1 } & \multicolumn{2}{|c|}{ MPW-2 } & \multirow{2}{*}{\begin{tabular}{|l|} 
MPW-2-1 \\
Round 1
\end{tabular}} & \multicolumn{2}{|c|}{ MPW-4 } & \multirow{2}{*}{\begin{tabular}{|l|} 
MPW-4-1 \\
Round 1
\end{tabular}} & \multicolumn{2}{|c|}{ MPW-4D } & \multirow{2}{*}{\begin{tabular}{|l|} 
MPW-4D-1 \\
Round 2
\end{tabular}} & \multicolumn{2}{|c|}{ MPW-7 } & \multicolumn{2}{|c|}{ MPW-7D } \\
\hline Week & & $\begin{array}{c}\text { Round } \\
1\end{array}$ & Round 2 & $\begin{array}{c}\text { Round } \\
1\end{array}$ & Round 2 & & Round 1 & Round 2 & & $\begin{array}{c}\text { Round } \\
1\end{array}$ & Round 2 & & $\begin{array}{c}\text { Round } \\
1\end{array}$ & \begin{tabular}{|c} 
Round \\
2
\end{tabular} & Round 1 & Round 2 \\
\hline \multirow{6}{*}{ Week 1} & Sample Date & $5 / 9 / 00$ & $10 / 11 / 00$ & $5 / 8 / 00$ & $10 / 10 / 00$ & $10 / 10 / 00$ & $5 / 9 / 00$ & $10 / 11 / 00$ & $5 / 9 / 00$ & $5 / 9 / 00$ & $10 / 11 / 00$ & $\mathrm{~N} / \mathrm{A}$ & $5 / 9 / 00$ & $10 / 11 / 00$ & $5 / 9 / 00$ & $10 / 11 / 00$ \\
\hline & $\mathrm{pH}$ (standard units) & 6.21 & 6.32 & 6.75 & 6.97 & 6.97 & 6.95 & 7.08 & 6.95 & 7.24 & 7.92 & $\mathrm{~N} / \mathrm{A}$ & 7.03 & 6.78 & 7.09 & 6.90 \\
\hline & Specific Conductance & 3120 & 3990 & 2840 & 3460 & 3460 & 2270 & 2190 & 2270 & 870 & 1070 & $\mathrm{~N} / \mathrm{A}$ & 2770 & 1540 & 1630 & 1960 \\
\hline & Temperature $\left({ }^{\circ} \mathrm{C}\right)$ & 15.8 & 12.8 & 15.0 & 14.5 & 14.5 & 13.7 & 14.7 & 13.7 & 14.2 & 13.9 & $\mathrm{~N} / \mathrm{A}$ & 16.4 & 16.8 & 19.7 & 15.4 \\
\hline & $\mathrm{TOX}(\mathrm{Fg} / \mathrm{L})$ & $20 U$ & $20 U$ & 29 & $20 \mathrm{U}$ & $20 \mathrm{U}$ & $20 \mathrm{U}$ & $20 \mathrm{U}$ & $20 \mathrm{U}$ & $20 \mathrm{U}$ & $20 \mathrm{U}$ & $\mathrm{N} / \mathrm{A}$ & $20 U$ & $20 U$ & 22 & $20 \mathrm{U}$ \\
\hline & TOC (mg/L) & 2.8 & 3.0 & 1.4 & 1.8 & 2.1 & $1.0 \mathrm{U}$ & 2.6 & 1.6 & $1.0 \mathrm{U}$ & 2.9 & $\mathrm{~N} / \mathrm{A}$ & 2.2 & 3.7 & 2.0 & 2.6 \\
\hline \multirow{6}{*}{ Week 2} & Sample Date & $5 / 16 / 00$ & $10 / 17 / 00$ & $5 / 15 / 00$ & $10 / 17 / 00$ & $5 / 1500$ & $5 / 16 / 00$ & $10 / 17 / 00$ & $\mathrm{~N} / \mathrm{A}$ & $5 / 16 / 00$ & $10 / 17 / 00$ & $\mathrm{~N} / \mathrm{A}$ & $5 / 16 / 00$ & $10 / 17 / 00$ & $5 / 16 / 00$ & $10 / 17 / 0$ \\
\hline & $\mathrm{pH}$ (standard units) & 6.58 & 6.13 & 7.22 & 6.72 & 7.22 & 7.48 & 6.79 & $\mathrm{~N} / \mathrm{A}$ & 7.82 & 7.84 & $\mathrm{~N} / \mathrm{A}$ & 7.08 & 6.30 & 7.25 & 6.43 \\
\hline & Specific Conductance & 4000 & 3690 & 3180 & 3140 & 3180 & 2780 & 2090 & $\mathrm{~N} / \mathrm{A}$ & 1070 & 940 & $\mathrm{~N} / \mathrm{A}$ & 3470 & 1500 & 1570 & 2020 \\
\hline & Temperature $\left({ }^{\circ} \mathrm{C}\right)$ & 13.6 & 14.4 & 13.4 & 15.1 & 13.4 & 13.1 & 14.8 & $\mathrm{~N} / \mathrm{A}$ & 13.7 & 14.8 & $\mathrm{~N} / \mathrm{A}$ & 14.8 & 16.9 & 13.8 & 15.5 \\
\hline & TOX (Fg/L) & $20 \mathrm{U}$ & $20 \mathrm{U}$ & $20 \mathrm{U}$ & $20 \mathrm{U}$ & $20 \mathrm{U}$ & $20 \mathrm{U}$ & $20 \mathrm{U}$ & $\mathrm{N} / \mathrm{A}$ & $20 \mathrm{U}$ & $20 \mathrm{U}$ & $\mathrm{N} / \mathrm{A}$ & $20 \mathrm{U}$ & $20 \mathrm{U}$ & $20 \mathrm{U}$ & $20 \mathrm{U}$ \\
\hline & TOC (mg/L) & 5.5 & 1.8 & 2.1 & 1.8 & 2.1 & 1.4 & 2.0 & $\mathrm{~N} / \mathrm{A}$ & 1.8 & 2.8 & $\mathrm{~N} / \mathrm{A}$ & 3.5 & 4.6 & 1.5 & 3.4 \\
\hline \multirow{6}{*}{ Week 3} & Sample Date & $5 / 23 / 00$ & $10 / 23 / 00$ & $5 / 22 / 00$ & $10 / 23 / 00$ & N/A & $5 / 23 / 00$ & $10 / 23 / 00$ & N/A & $5 / 23 / 00$ & $10 / 23 / 00$ & $10 / 23 / 00$ & $5 / 23 / 00$ & $10 / 23 / 00$ & $5 / 23 / 00$ & $10 / 23 / 00$ \\
\hline & pH (standard units) & 6.74 & 6.90 & 6.76 & 6.81 & N/A & 7.15 & 6.86 & N/A & 8.05 & 7.69 & 7.69 & 6.94 & 6.82 & 7.17 & 6.88 \\
\hline & Specific Conductance & 3970 & 3380 & 3130 & 3060 & N/A & 2430 & 2140 & N/A & 950 & 930 & 930 & 2650 & 1340 & 1380 & 1890 \\
\hline & Temperature $\left({ }^{0} \mathrm{C}\right)$ & 14.3 & 14.8 & 14.4 & 14.9 & N/A & 13.5 & 15.1 & N/A & 13.5 & 14.7 & 14.7 & 15.1 & 18.3 & 14.8 & 21.0 \\
\hline & TOX (Fg/L) & $20 \mathrm{U}$ & $20 \mathrm{U}$ & $20 \mathrm{U}$ & $20 \mathrm{U}$ & N/A & $20 \mathrm{U}$ & $20 \mathrm{U}$ & $20 \mathrm{U}$ & $20 \mathrm{U}$ & $20 \mathrm{U}$ & $20 \mathrm{U}$ & $20 \mathrm{U}$ & $20 \mathrm{U}$ & $20 \mathrm{U}$ & $20 \mathrm{U}$ \\
\hline & TOC (mg/L) & 3.5 & 2.7 & 1.4 & 2.0 & N/A & 1.4 & 2.4 & N/A & 2.2 & 2.7 & 3.6 & 3.4 & 3.3 & 2.1 & 3.6 \\
\hline \multirow{6}{*}{ Week 4} & Sample Date & $5 / 30 / 00$ & $10 / 30 / 00$ & $5 / 30 / 00$ & $10 / 30 / 00$ & $\mathrm{~N} / \mathrm{A}$ & $5 / 30 / 00$ & $10 / 30 / 00$ & $\mathrm{~N} / \mathrm{A}$ & $5 / 30 / 00$ & $10 / 30 / 00$ & $\mathrm{~N} / \mathrm{A}$ & $5 / 30 / 00$ & $10 / 30 / 00$ & $5 / 30 / 00$ & $10 / 30 / 00$ \\
\hline & $\mathrm{pH}$ (standard units) & 7.23 & 7.17 & 6.99 & 6.87 & $\mathrm{~N} / \mathrm{A}$ & 7.08 & 6.38 & $\mathrm{~N} / \mathrm{A}$ & 8.01 & 7.28 & $\mathrm{~N} / \mathrm{A}$ & 6.97 & 6.95 & 7.04 & 6.89 \\
\hline & Specific Conductance & 3480 & 4100 & 3430 & 3240 & $\mathrm{~N} / \mathrm{A}$ & 2630 & 2360 & $\mathrm{~N} / \mathrm{A}$ & 1030 & 570 & $\mathrm{~N} / \mathrm{A}$ & 2320 & 1600 & 1880 & 2210 \\
\hline & Temperature $\left({ }^{\circ} \mathrm{C}\right)$ & 14.7 & 14.0 & 13.9 & 14.2 & $\mathrm{~N} / \mathrm{A}$ & 13.9 & 14.6 & $\mathrm{~N} / \mathrm{A}$ & 14.6 & 13.8 & $\mathrm{~N} / \mathrm{A}$ & 15.8 & 17.6 & 17.0 & 18.8 \\
\hline & TOX (Fg/L) & $20 \mathrm{U}$ & $20 \mathrm{U}$ & $20 \mathrm{U}$ & $20 \mathrm{U}$ & $\mathrm{N} / \mathrm{A}$ & $20 \mathrm{U}$ & $20 \mathrm{U}$ & $\mathrm{N} / \mathrm{A}$ & $20 \mathrm{U}$ & $20 \mathrm{U}$ & $\mathrm{N} / \mathrm{A}$ & $20 \mathrm{U}$ & $20 \mathrm{U}$ & $20 \mathrm{U}$ & $20 \mathrm{U}$ \\
\hline & TOC (mg/L) & 1.3 & 3.5 & 1.4 & 2.6 & $\mathrm{~N} / \mathrm{A}$ & $1.0 \mathrm{U}$ & 3.1 & $\mathrm{~N} / \mathrm{A}$ & 1.4 & 23 & $\mathrm{~N} / \mathrm{A}$ & 2.9 & 3.4 & 2.1 & 4.1 \\
\hline \multirow{5}{*}{$\begin{array}{l}2000 \\
\text { Range }\end{array}$} & $\mathrm{pH}$ (standard units) & \multicolumn{2}{|c|}{$6.13-7.23$} & \multicolumn{2}{|c|}{$6.72-7.22$} & $\mathrm{~N} / \mathrm{A}$ & \multicolumn{2}{|c|}{$6.38-7.48$} & $\mathrm{~N} / \mathrm{A}$ & \multicolumn{2}{|c|}{$7.24-8.05$} & $\mathrm{~N} / \mathrm{A}$ & \multicolumn{2}{|c|}{$6.30-7.08$} & \multicolumn{2}{|c|}{$6.43-7.25$} \\
\hline & Specific Conductance & \multicolumn{2}{|c|}{$3120-4100$} & \multicolumn{2}{|c|}{$2840-3460$} & $\mathrm{~N} / \mathrm{A}$ & \multicolumn{2}{|c|}{$2090-2780$} & $\mathrm{~N} / \mathrm{A}$ & 570 & -1070 & $\mathrm{~N} / \mathrm{A}$ & 1340 & -3470 & 1380 & -2210 \\
\hline & Temperature $\left({ }^{\circ} \mathrm{C}\right)$ & 12.8 & -15.8 & 13.4 & -15.1 & $\mathrm{~N} / \mathrm{A}$ & 13.1 & 15.1 & $\mathrm{~N} / \mathrm{A}$ & 13.5 & -14.8 & $\mathrm{~N} / \mathrm{A}$ & 14.8 & -18.3 & 13.8 & -21.0 \\
\hline & TOX (Fg/L) & & $0 \mathrm{U}$ & 20 & $J-29$ & $\mathrm{~N} / \mathrm{A}$ & & & $\mathrm{N} / \mathrm{A}$ & & $0 \mathrm{U}$ & $\mathrm{N} / \mathrm{A}$ & & $\mathrm{U}$ & $20 U$ & -22 \\
\hline & $\mathrm{TOC}(\mathrm{mg} / \mathrm{L})$ & 1.3 & -5.5 & & -2.6 & $\mathrm{~N} / \mathrm{A}$ & 1.0 & -3.1 & $\mathrm{~N} / \mathrm{A}$ & 1.0 & $U-23$ & $\mathrm{~N} / \mathrm{A}$ & 2.2 & -4.6 & 1.5 & -4.1 \\
\hline
\end{tabular}

Specific conductance unit = Fmhos $/ \mathrm{cm} @ 25 \mathrm{EC} ; \mathrm{U}=\mathrm{Not}$ Detected; $\mathrm{N} / \mathrm{A}=\mathrm{N}$ ot applicable; TOX = total organic halide; TOC = total organic carbon 
Table 10. NETL-PGH 2000 Groundwater Detection Monitoring Program

Results of Analysis - Groundwater Samples, Main Plateau - Contamination Indicator Constituents

(continued)

\begin{tabular}{|c|c|c|c|c|c|c|c|c|c|c|c|c|c|c|c|}
\hline & \multirow{3}{*}{\begin{tabular}{|l|} 
Constituents \\
Sample Event
\end{tabular}} & \multicolumn{14}{|c|}{ Well } \\
\hline & & \multicolumn{2}{|c|}{ MPW-8 } & \multirow{2}{*}{\begin{tabular}{|l|} 
MPW-8-1 \\
Round 2 \\
\end{tabular}} & \multicolumn{2}{|c|}{ MPW-9 } & \multicolumn{2}{|c|}{ MPW-10 } & \multirow{2}{*}{\begin{tabular}{|l|} 
MPW-10-1 \\
Round 1
\end{tabular}} & \multicolumn{2}{|c|}{ MPW-11 } & \multirow{2}{*}{\begin{tabular}{|c|} 
MPW-11-1 \\
Round 1
\end{tabular}} & \multicolumn{2}{|c|}{ MPW-12 } & \multirow{2}{*}{\begin{tabular}{|c} 
MPW-12-1 \\
Round 2
\end{tabular}} \\
\hline Well & & Round 1 & $\begin{array}{c}\text { Round } \\
2\end{array}$ & & $\begin{array}{c}\text { Round } \\
1\end{array}$ & Round 2 & Round 1 & Round 2 & & Round 1 & Round 2 & & Round 1 & Round 2 & \\
\hline \multirow{6}{*}{ Week 1} & Sample Date & $5 / 9 / 00$ & $10 / 11 / 00$ & $\mathrm{~N} / \mathrm{A}$ & $5 / 9 / 00$ & $10 / 11 / 00$ & $5 / 9 / 00$ & $10 / 11 / 00$ & $\mathrm{~N} / \mathrm{A}$ & $5 / 9 / 00$ & $10 / 11 / 00$ & N/A & $5 / 8 / 00$ & $10 / 10 / 00$ & N/A \\
\hline & $\mathrm{pH}$ (standard units) & 6.75 & 6.53 & $\mathrm{~N} / \mathrm{A}$ & 7.52 & 7.43 & 7.82 & 8.55 & $\mathrm{~N} / \mathrm{A}$ & 6.54 & 6.54 & N/A & 6.71 & 6.76 & N/A \\
\hline & Specific Conductance & 3500 & 4560 & $\mathrm{~N} / \mathrm{A}$ & 770 & 820 & 700 & 790 & $\mathrm{~N} / \mathrm{A}$ & 2460 & 2500 & N/A & 5490 & 5500 & N/A \\
\hline & Temperature $\left({ }^{\circ} \mathrm{C}\right)$ & 18.2 & 18.6 & $\mathrm{~N} / \mathrm{A}$ & 13.6 & 13.2 & 13.8 & 12.8 & $\mathrm{~N} / \mathrm{A}$ & 17.0 & 16.2 & N/A & 17.8 & 16.2 & N/A \\
\hline & $\mathrm{TOX}(\mathrm{Fg} / \mathrm{L})$ & 37 & $20 \mathrm{U}$ & N/A & $20 \mathrm{U}$ & $20 \mathrm{U}$ & 26 & $20 \mathrm{U}$ & $\mathrm{N} / \mathrm{A}$ & $20 \mathrm{U}$ & $20 \mathrm{U}$ & N/A & 28 & $20 \mathrm{U}$ & N/A \\
\hline & $\mathrm{TOC}(\mathrm{mg} / \mathrm{L})$ & $1.0 \mathrm{U}$ & 3.4 & $\mathrm{~N} / \mathrm{A}$ & $1.0 \mathrm{U}$ & 2.0 & $1.0 \mathrm{U}$ & 2.1 & $\mathrm{~N} / \mathrm{A}$ & $1.0 \mathrm{U}$ & 1.4 & N/A & $1.0 \mathrm{U}$ & 1.9 & N/A \\
\hline \multirow{6}{*}{ Week 2} & Sample Date & $5 / 16 / 00$ & $10 / 17 / 00$ & $\mathrm{~N} / \mathrm{A}$ & $5 / 16 / 00$ & $10 / 17 / 00$ & $5 / 16 / 00$ & $10 / 17 / 00$ & $\mathrm{~N} / \mathrm{A}$ & $5 / 16 / 00$ & $10 / 16 / 00$ & N/A & $5 / 15 / 00$ & $10 / 16 / 00$ & $10 / 16 / 00$ \\
\hline & $\mathrm{pH}$ (standard units) & 6.73 & 6.17 & $\mathrm{~N} / \mathrm{A}$ & 7.66 & 5.80 & 7.73 & 6.43 & $\mathrm{~N} / \mathrm{A}$ & 6.85 & 7.17 & N/A & 7.30 & 6.87 & 6.87 \\
\hline & Specific Conductance & 4300 & 4060 & $\mathrm{~N} / \mathrm{A}$ & 930 & 750 & 870 & 750 & $\mathrm{~N} / \mathrm{A}$ & 3060 & 2210 & N/A & 5270 & 6230 & 6230 \\
\hline & Temperature $\left({ }^{0} \mathrm{C}\right)$ & 16.2 & 19.3 & $\mathrm{~N} / \mathrm{A}$ & 11.7 & 12.5 & 12.1 & 12.7 & $\mathrm{~N} / \mathrm{a}$ & 15.5 & 17.2 & $\mathrm{~N} / \mathrm{A}$ & 15.1 & 17.0 & 17.0 \\
\hline & $\mathrm{TOX}(\mathrm{Fg} / \mathrm{L})$ & $20 \mathrm{U}$ & $20 \mathrm{U}$ & $\mathrm{N} / \mathrm{A}$ & $20 \mathrm{U}$ & $20 \mathrm{U}$ & $20 \mathrm{U}$ & $20 \mathrm{U}$ & $\mathrm{N} / \mathrm{A}$ & $20 \mathrm{U}$ & $20 \mathrm{U}$ & N/A & $20 \mathrm{U}$ & $20 \mathrm{U}$ & $20 \mathrm{U}$ \\
\hline & TOC (mg/L) & 2.6 & 4.4 & $\mathrm{~N} / \mathrm{A}$ & 1.6 & 2.6 & 1.7 & 4.3 & $\mathrm{~N} / \mathrm{A}$ & 2.0 & 1.5 & N/A & 2.2 & 1.8 & 1.4 \\
\hline \multirow{5}{*}{ Week 3} & Sample Date & $5 / 23 / 00$ & $10 / 23 / 00$ & $\mathrm{~N} / \mathrm{A}$ & $5 / 23 / 00$ & $10 / 23 / 00$ & $5 / 23 / 00$ & $10 / 23 / 00$ & $\mathrm{~N} / \mathrm{A}$ & $5 / 23 / 00$ & $10 / 23 / 00$ & $5 / 23 / 00$ & $5 / 22 / 00$ & $10 / 23 / 00$ & $\mathrm{~N} / \mathrm{A}$ \\
\hline & Specific Conductance & 3710 & 3940 & $\mathrm{~N} / \mathrm{A}$ & 810 & 730 & 740 & 720 & $\mathrm{~N} / \mathrm{A}$ & 2770 & 2180 & 2770 & 4420 & 5210 & $\mathrm{~N} / \mathrm{A}$ \\
\hline & Temperature $\left({ }^{\circ} \mathrm{C}\right)$ & 17.5 & 19.0 & N/A & 12.0 & 13.5 & 12.4 & 13.4 & N/A & 16.0 & 17.3 & 16.0 & 16.7 & 16.6 & N/A \\
\hline & $\mathrm{TOX}(\mathrm{Fg} / \mathrm{L})$ & $20 U$ & $20 U$ & $\mathrm{~N} / \mathrm{A}$ & $20 U$ & $20 U$ & $20 U$ & $20 U$ & $\mathrm{~N} / \mathrm{A}$ & $20 U$ & $20 U$ & $20 U$ & $20 U$ & $20 U$ & N/A \\
\hline & $\mathrm{TOC}(\mathrm{mg} / \mathrm{L})$ & 2.2 & 4.2 & $\mathrm{~N} / \mathrm{A}$ & 1.6 & 3.0 & 1.7 & 3.5 & $\mathrm{~N} / \mathrm{A}$ & 1.2 & 1.7 & 1.3 & 1.2 & 2.8 & N/A \\
\hline \multirow{6}{*}{ Week 4} & Sample Date & $5 / 30 / 00$ & $10 / 30 / 00$ & $10 / 30 / 00$ & $5 / 30 / 00$ & $10 / 30 / 00$ & $5 / 30 / 00$ & $10 / 30 / 00$ & $5 / 30 / 00$ & $5 / 30 / 00$ & $10 / 30 / 00$ & N/A & $5 / 30 / 00$ & $10 / 30 / 00$ & $\mathrm{~N} / \mathrm{A}$ \\
\hline & $\mathrm{pH}$ (standard units) & 6.82 & 6.84 & 6.84 & 7.55 & 7.24 & 8.69 & 9.17 & 8.69 & 7.05 & 7.04 & N/A & 7.00 & 7.03 & N/A \\
\hline & Specific Conductance & 4030 & 4190 & 4190 & 870 & 850 & 810 & 840 & 810 & 2910 & 2350 & $\mathrm{~N} / \mathrm{A}$ & 4130 & 5750 & $\mathrm{~N} / \mathrm{A}$ \\
\hline & Temperature $\left({ }^{0} \mathrm{C}\right)$ & 18.3 & 18.1 & 18.1 & 15.3 & 12.4 & 13.1 & 13.0 & 13.1 & 17.1 & 16.7 & $\mathrm{~N} / \mathrm{A}$ & 15.8 & 15.4 & $\mathrm{~N} / \mathrm{A}$ \\
\hline & $\mathrm{TOX}(\mathrm{Fg} / \mathrm{L})$ & $20 \mathrm{U}$ & $20 \mathrm{U}$ & $20 \mathrm{U}$ & $20 \mathrm{U}$ & $20 \mathrm{U}$ & $20 U$ & $20 \mathrm{U}$ & $20 \mathrm{U}$ & $20 \mathrm{U}$ & $20 \mathrm{U}$ & $\mathrm{N} / \mathrm{A}$ & $20 \mathrm{U}$ & $20 \mathrm{U}$ & $\mathrm{N} / \mathrm{A}$ \\
\hline & $\mathrm{TOC}(\mathrm{mg} / \mathrm{L})$ & 2.2 & 3.6 & 3.1 & 1.4 & 2.1 & 1.8 & $3.18 \mathrm{~J}$ & 2.1 & 1.4 & 2.0 & $\mathrm{~N} / \mathrm{A}$ & 1.5 & 2.4 & $\mathrm{~N} / \mathrm{A}$ \\
\hline \multirow{5}{*}{2000 Range } & pH (standard units) & \multicolumn{2}{|c|}{$6.17-6.84$} & $\mathrm{~N} / \mathrm{A}$ & 5.8 & -7.98 & \multicolumn{2}{|c|}{$6.43-9.17$} & $\mathrm{~N} / \mathrm{A}$ & \multicolumn{2}{|c|}{$6.54-7.17$} & N/A & \multicolumn{2}{|c|}{$6.47-7.30$} & $\mathrm{~N} / \mathrm{A}$ \\
\hline & Specific Conductance & \multicolumn{2}{|c|}{$3500-4560$} & $\mathrm{~N} / \mathrm{A}$ & & -930 & \multicolumn{2}{|c|}{$700-870$} & $\mathrm{~N} / \mathrm{A}$ & \multicolumn{2}{|c|}{$2180-3060$} & $\mathrm{~N} / \mathrm{A}$ & \multicolumn{2}{|c|}{$4130-3060$} & $\mathrm{~N} / \mathrm{A}$ \\
\hline & Temperature $\left({ }^{\circ} \mathrm{C}\right)$ & \multicolumn{2}{|c|}{$16.2-19.3$} & $\mathrm{~N} / \mathrm{A}$ & 11. & -15.3 & $12.1-$ & 13.8 & $\mathrm{~N} / \mathrm{A}$ & 15.5 & -17.3 & $\mathrm{~N} / \mathrm{A}$ & $15.1-$ & -17.8 & $\mathrm{~N} / \mathrm{A}$ \\
\hline & $\mathrm{TOX}(\mathrm{Fg} / \mathrm{L})$ & $20 \mathrm{U}$ & -37 & $\mathrm{~N} / \mathrm{A}$ & & $0 \mathrm{U}$ & $20 \mathrm{U}$ & -26 & $\mathrm{~N} / \mathrm{A}$ & & $U$ & $\mathrm{~N} / \mathrm{A}$ & $20 \mathrm{U}$ & -28 & $\mathrm{~N} / \mathrm{A}$ \\
\hline & $\mathrm{TOC}(\mathrm{mg} / \mathrm{L})$ & $1.0 \mathrm{U}$ & -4.4 & $\mathrm{~N} / \mathrm{A}$ & 1.0 & J -3.0 & $1.0 \mathrm{U}$ & -4.3 & $\mathrm{~N} / \mathrm{A}$ & $1.0 \mathrm{~L}$ & -2.0 & N/A & $1.0 \mathrm{U}$ & -2.8 & N/A \\
\hline
\end{tabular}


Table 11. NETL-PGH 2000 Groundwater Detection Monitoring Program Results of Analysis - Groundwater Samples, Valley Fill - Contamination Indicator Constituents

\begin{tabular}{|c|c|c|c|c|c|c|c|c|c|c|c|c|c|c|c|c|c|}
\hline \multirow[b]{3}{*}{ Week } & \multirow{3}{*}{\begin{tabular}{|l|} 
Constituent \\
Sample Event \\
\end{tabular}} & \multicolumn{16}{|c|}{ Well } \\
\hline & & \multicolumn{2}{|c|}{ VFW-1 } & \multirow{2}{*}{\begin{tabular}{|c|} 
VFW-1-1 \\
Round \\
1
\end{tabular}} & \multicolumn{2}{|c|}{ VFW-2 } & \multirow{2}{*}{\begin{tabular}{|c|} 
VFW-2-1 \\
Round \\
1
\end{tabular}} & \multicolumn{2}{|c|}{ VFW-3 } & \multirow{2}{*}{\begin{tabular}{|c|} 
VFW-3-1 \\
$\begin{array}{c}\text { Round } \\
2\end{array}$ \\
\end{tabular}} & \multicolumn{2}{|c|}{ VFW-4 } & \multirow{2}{*}{\begin{tabular}{|c|} 
VFW-4-1 \\
$\begin{array}{c}\text { Round } \\
2\end{array}$ \\
\end{tabular}} & \multicolumn{2}{|c|}{ VFW-5 } & \multicolumn{2}{|c|}{ VFW - 6} \\
\hline & & $\begin{array}{c}\text { Round } \\
1\end{array}$ & $\begin{array}{c}\text { Round } \\
2\end{array}$ & & $\begin{array}{c}\text { Round } \\
1\end{array}$ & $\begin{array}{c}\text { Round } \\
2\end{array}$ & & $\begin{array}{c}\text { Round } \\
1\end{array}$ & $\begin{array}{c}\text { Round } \\
2\end{array}$ & & \begin{tabular}{|c|} 
Round \\
1
\end{tabular} & \begin{tabular}{|c} 
Round \\
2
\end{tabular} & & $\begin{array}{c}\text { Round } \\
1\end{array}$ & \begin{tabular}{|c|} 
Round \\
2
\end{tabular} & $\begin{array}{c}\text { Round } \\
1\end{array}$ & \begin{tabular}{|c|} 
Round \\
2
\end{tabular} \\
\hline \multirow{6}{*}{ Week 1} & Sample Date & $5 / 8 / 00$ & $10 / 10 / 00$ & $\mathrm{~N} / \mathrm{A}$ & $5 / 8 / 00$ & $10 / 10 / 00$ & $\mathrm{~N} / \mathrm{A}$ & $5 / 8 / 00$ & $10 / 10 / 00$ & $\mathrm{~N} / \mathrm{A}$ & $5 / 8 / 00$ & $10 / 10 / 00$ & $\mathrm{~N} / \mathrm{A}$ & $5 / 8 / 00$ & $10 / 10 / 00$ & $5 / 8 / 00$ & $10 / 10 / 00$ \\
\hline & pH (standard units) & 7.75 & 7.84 & $\mathrm{~N} / \mathrm{A}$ & 6.95 & 7.07 & $\mathrm{~N} / \mathrm{A}$ & 6.83 & 7.02 & $\mathrm{~N} / \mathrm{A}$ & 6.55 & 6.43 & $\mathrm{~N} / \mathrm{A}$ & 7.09 & 7.08 & 7.32 & 7.07 \\
\hline & Specific Conductance & 900 & 890 & $\mathrm{~N} / \mathrm{A}$ & 3710 & 2160 & $\mathrm{~N} / \mathrm{A}$ & 2260 & 2600 & $\mathrm{~N} / \mathrm{A}$ & 2100 & 2240 & $\mathrm{~N} / \mathrm{A}$ & 2980 & 3040 & 3140 & 3150 \\
\hline & Temperature $\left({ }^{\circ} \mathrm{C}\right)$ & 13.6 & 12.4 & $\mathrm{~N} / \mathrm{A}$ & 12.7 & 14.0 & $\mathrm{~N} / \mathrm{A}$ & 16.8 & 15.1 & $\mathrm{~N} / \mathrm{A}$ & 15.5 & 15.1 & $\mathrm{~N} / \mathrm{A}$ & 13.6 & 13.5 & 12.5 & 14.8 \\
\hline & $\overline{T O X}(\mathrm{Fg} / \mathrm{L})$ & $20 \mathrm{U}$ & $20 \mathrm{U}$ & $\mathrm{N} / \mathrm{A}$ & $20 \mathrm{U}$ & $20 \mathrm{U}$ & $\mathrm{N} / \mathrm{A}$ & $20 \mathrm{U}$ & $20 \mathrm{U}$ & $\mathrm{N} / \mathrm{A}$ & $20 \mathrm{U}$ & $20 \mathrm{U}$ & $\mathrm{N} / \mathrm{A}$ & $20 \mathrm{U}$ & $20 \mathrm{U}$ & $20 \mathrm{U}$ & $20 \mathrm{U}$ \\
\hline & TOC (mg/L) & 5.8 & 2.4 & $\mathrm{~N} / \mathrm{A}$ & 1.2 & 2.2 & $\mathrm{~N} / \mathrm{A}$ & 1.3 & 3.3 & $\mathrm{~N} / \mathrm{A}$ & $1.0 \mathrm{U}$ & 2.8 & $\mathrm{~N} / \mathrm{A}$ & 18 & 6.7 & 2.4 & 3.2 \\
\hline \multirow{6}{*}{ Week 2} & Sample Date & $5 / 15 / 00$ & $10 / 16 / 00$ & $\mathrm{~N} / \mathrm{A}$ & $5 / 15 / 00$ & $10 / 16 / 00$ & $5 / 15 / 00$ & $5 / 15 / 00$ & $10 / 16 / 00$ & $10 / 16 / 00$ & $5 / 15 / 00$ & $10 / 16 / 00$ & $\mathrm{~N} / \mathrm{A}$ & $5 / 15 / 00$ & $10 / 16 / 00$ & $5 / 15 / 00$ & $10 / 16 / 00$ \\
\hline & $\mathrm{pH}$ (standard units) & 7.95 & 8.01 & $\mathrm{~N} / \mathrm{A}$ & 6.63 & 7.12 & 6.63 & 6.85 & 7.04 & 7.04 & 6.53 & 6.81 & $\mathrm{~N} / \mathrm{A}$ & 6.84 & 6.93 & 6.63 & 6.58 \\
\hline & Specific Conductance & 960 & 1050 & $\mathrm{~N} / \mathrm{A}$ & 4200 & 2200 & 4200 & 2530 & 2720 & 2720 & 2260 & 2220 & $\mathrm{~N} / \mathrm{A}$ & 3410 & 3170 & 3520 & 3220 \\
\hline & Temperature $\left({ }^{\circ} \mathrm{C}\right)$ & 12.7 & 13.6 & $\mathrm{~N} / \mathrm{A}$ & 11.9 & 14.6 & 11.9 & 14.8 & 16.0 & 16.0 & 14.9 & 15.9 & $\mathrm{~N} / \mathrm{A}$ & 13.2 & 14.1 & 12.0 & 15.3 \\
\hline & TOX (Fg/L) & 24 & $20 \mathrm{U}$ & $\mathrm{N} / \mathrm{A}$ & $20 \mathrm{U}$ & $20 \mathrm{U}$ & $20 \mathrm{U}$ & $20 \mathrm{U}$ & $20 \mathrm{U}$ & $20 \mathrm{U}$ & 22 & $20 \mathrm{U}$ & $\mathrm{N} / \mathrm{A}$ & $20 \mathrm{U}$ & $20 \mathrm{U}$ & $20 \mathrm{U}$ & $20 \mathrm{U}$ \\
\hline & TOC $(\mathrm{mg} / \mathrm{L})$ & 4.2 & 7.4 & $\mathrm{~N} / \mathrm{A}$ & 2.3 & 2.8 & 1.9 & 2.1 & 4.7 & 4.5 & 1.5 & 3.1 & $\mathrm{~N} / \mathrm{A}$ & 3.8 & 4.7 & 3.5 & 2.8 \\
\hline \multirow{6}{*}{ Week 3} & Sample Date & $5 / 22 / 00$ & $10 / 23 / 00$ & $5 / 22 / 00$ & $5 / 22 / 00$ & $10 / 23 / 00$ & $\mathrm{~N} / \mathrm{A}$ & $5 / 22 / 00$ & $10 / 23 / 00$ & $\mathrm{~N} / \mathrm{A}$ & $5 / 22 / 00$ & $10 / 23 / 00$ & $10 / 23 / 00$ & $5 / 22 / 00$ & $10 / 23 / 00$ & $5 / 22 / 00$ & $10 / 23 / 00$ \\
\hline & $\mathrm{pH}$ (standard units) & 7.98 & 7.72 & 7.98 & 6.95 & 6.84 & $\mathrm{~N} / \mathrm{A}$ & 6.97 & 9.93 & $\mathrm{~N} / \mathrm{A}$ & 6.65 & 6.84 & 6.84 & 6.96 & 6.85 & 7.05 & 6.62 \\
\hline & Specific Conductance & 1050 & 1040 & 1050 & 3850 & 2110 & $\mathrm{~N} / \mathrm{A}$ & 2440 & 2640 & $\mathrm{~N} / \mathrm{A}$ & 2200 & 2150 & 2150 & 3330 & 3040 & 3520 & 3030 \\
\hline & Temperature $\left({ }^{\circ} \mathrm{C}\right)$ & 13.1 & 13.4 & 13.1 & 12.4 & 15.9 & $\mathrm{~N} / \mathrm{A}$ & 15.3 & 15.6 & $\mathrm{~N} / \mathrm{A}$ & 15.2 & 15.9 & 15.9 & 13.3 & 13.2 & 12.7 & 14.8 \\
\hline & TOX (Fg/L) & $20 \mathrm{U}$ & $20 \mathrm{U}$ & $20 \mathrm{U}$ & $20 \mathrm{U}$ & $20 \mathrm{U}$ & $\mathrm{N} / \mathrm{A}$ & $20 \mathrm{U}$ & $20 \mathrm{U}$ & $\mathrm{N} / \mathrm{A}$ & $20 \mathrm{U}$ & $20 \mathrm{U}$ & $20 \mathrm{U}$ & $20 \mathrm{U}$ & $20 \mathrm{U}$ & $20 \mathrm{U}$ & $20 \mathrm{U}$ \\
\hline & TOC (mg/L) & 3.5 & 2.8 & 3.2 & 2.2 & 2.9 & $\mathrm{~N} / \mathrm{A}$ & 2.3 & 3.4 & $\mathrm{~N} / \mathrm{A}$ & 1.8 & 3.8 & 3.6 & 3.7 & 4.6 & 3.2 & 3.1 \\
\hline \multirow{6}{*}{ Week 4} & Sample Date & $5 / 30 / 00$ & $10 / 30 / 00$ & $\mathrm{~N} / \mathrm{A}$ & $5 / 30 / 00$ & $10 / 30 / 00$ & $\mathrm{~N} / \mathrm{A}$ & $5 / 30 / 00$ & $10 / 30 / 00$ & $\mathrm{~N} / \mathrm{A}$ & $5 / 30 / 00$ & $10 / 30 / 00$ & $\mathrm{~N} / \mathrm{A}$ & $5 / 30 / 00$ & $10 / 30 / 00$ & $5 / 30 / 00$ & $10 / 30 / 00$ \\
\hline & $\mathrm{pH}$ (standard units) & 7.92 & 8.43 & $\mathrm{~N} / \mathrm{A}$ & 6.99 & 6.93 & $\mathrm{~N} / \mathrm{A}$ & 6.93 & 7.11 & $\mathrm{~N} / \mathrm{A}$ & 6.60 & 6.61 & $\mathrm{~N} / \mathrm{A}$ & 6.99 & 6.92 & 7.17 & 6.53 \\
\hline & Specific Conductance & 1280 & 1170 & $\mathrm{~N} / \mathrm{A}$ & 3940 & 2310 & $\mathrm{~N} / \mathrm{A}$ & 2580 & 2870 & $\mathrm{~N} / \mathrm{A}$ & 2400 & 2290 & $\mathrm{~N} / \mathrm{A}$ & 3350 & 3310 & 3830 & 3250 \\
\hline & Temperature $\left({ }^{\circ} \mathrm{C}\right)$ & 12.9 & 12.9 & $\mathrm{~N} / \mathrm{A}$ & 12.4 & 14.3 & $\mathrm{~N} / \mathrm{A}$ & 15.1 & 15.1 & $\mathrm{~N} / \mathrm{A}$ & 14.8 & 15.7 & $\mathrm{~N} / \mathrm{A}$ & 13.4 & 13.6 & 12.7 & 14.5 \\
\hline & TOX (Fg/L) & $20 \mathrm{U}$ & $20 \mathrm{U}$ & $\mathrm{N} / \mathrm{A}$ & $20 \mathrm{U}$ & $20 \mathrm{U}$ & $\mathrm{N} / \mathrm{A}$ & $20 \mathrm{U}$ & $20 \mathrm{U}$ & $\mathrm{N} / \mathrm{A}$ & $20 \mathrm{U}$ & $20 \mathrm{U}$ & $\mathrm{N} / \mathrm{A}$ & $20 \mathrm{U}$ & $20 \mathrm{U}$ & $20 \mathrm{U}$ & $20 \mathrm{U}$ \\
\hline & TOC (mg/L) & 2.7 & 5.1 & $\mathrm{~N} / \mathrm{A}$ & 2.1 & 3.5 & $\mathrm{~N} / \mathrm{A}$ & 2.2 & 4.6 & $\mathrm{~N} / \mathrm{A}$ & 1.9 & 2.9 & $\mathrm{~N} / \mathrm{A}$ & 3.4 & 4.5 & 3.1 & 3.0 \\
\hline \multirow{5}{*}{$\begin{array}{l}2000 \\
\text { Range }\end{array}$} & $\mathrm{pH}$ (standard units) & \multicolumn{2}{|c|}{$7.72-8.43$} & $\mathrm{~N} / \mathrm{A}$ & \multicolumn{2}{|c|}{$6.84-7.12$} & $\mathrm{~N} / \mathrm{A}$ & \multicolumn{2}{|c|}{$6.83-7.11$} & $\mathrm{~N} / \mathrm{A}$ & \multicolumn{2}{|c|}{$6.43-6.84$} & $\mathrm{~N} / \mathrm{A}$ & \multicolumn{2}{|c|}{$6.84-7.09$} & \multicolumn{2}{|c|}{$6.53-7.32$} \\
\hline & Specific Conductance & $890-$ & 1280 & $\mathrm{~N} / \mathrm{A}$ & 2110 & -4200 & $\mathrm{~N} / \mathrm{A}$ & 2260 & -2870 & $\mathrm{~N} / \mathrm{A}$ & 2100 & -2400 & $\mathrm{~N} / \mathrm{A}$ & 2980 & -3410 & 3030 & -3830 \\
\hline & Temperature $\left({ }^{\circ} \mathrm{C}\right)$ & 12.4 & -13.6 & & 11.9 & -15.9 & $\mathrm{~N} / \mathrm{A}$ & 14.8 & -16.8 & $\mathrm{~N} / \mathrm{A}$ & 14.8 & -15.9 & $\mathrm{~N} / \mathrm{A}$ & 13.2 & -14.1 & 12.0 & -15.3 \\
\hline & TOX (Fg/L) & $20 \mathrm{U}$ & $J-24$ & $\mathrm{~N} / \mathrm{A}$ & 20 & $\overline{O U}$ & $\mathrm{~N} / \mathrm{A}$ & 20 & $\bar{U}$ & $\mathrm{~N} / \mathrm{A}$ & $20 \mathrm{U}$ & -22 & $\mathrm{~N} / \mathrm{A}$ & 20 & 5 & 20 & $\mathrm{U}$ \\
\hline & $\mathrm{TOC}(\mathrm{mg} / \mathrm{L})$ & 2.4 & -7.4 & $\mathrm{~N} / \mathrm{A}$ & 1.2 & -3.5 & $\mathrm{~N} / \mathrm{A}$ & 1.3 & -4.7 & $\mathrm{~N} / \mathrm{A}$ & $1.0 \mathrm{~L}$ & $J-3.8$ & $\mathrm{~N} / \mathrm{A}$ & & -18 & 2.4 & -3.5 \\
\hline
\end{tabular}

Specific conductance unit $=\mathrm{Fmhos} / \mathrm{cm} @ 25 \mathrm{EC} ; \mathrm{U}=$ Not Detected; N/A = not applicable; TOX = total organic halide; TOC = total organic carbon. 
Table 11. NETL-PGH 2000 Groundwater Detection Monitoring Program Results of Analysis - Groundwater Samples, Valley Fill - Contamination Indicator Constituents

(continued)

\begin{tabular}{|c|c|c|c|c|c|c|c|c|c|c|c|c|c|c|c|c|}
\hline \multirow{3}{*}{\begin{tabular}{|l|} 
\\
Week
\end{tabular}} & \multirow{3}{*}{$\begin{array}{l}\text { Constituents } \\
\text { Sample Event }\end{array}$} & \multicolumn{15}{|c|}{ Well } \\
\hline & & \multirow{2}{*}{\begin{tabular}{|l|} 
VFW-6-1 \\
Round1 \\
\end{tabular}} & \multicolumn{2}{|c|}{ VFW-7 } & \multirow{2}{*}{\begin{tabular}{|c|} 
VFW-7-1 \\
2
\end{tabular}} & \multicolumn{2}{|c|}{ VFW-9 } & \multicolumn{2}{|c|}{ VFW-10 } & \multirow{2}{*}{\begin{tabular}{|l|} 
VFW-10-1 \\
Round 1/2 \\
\end{tabular}} & \multicolumn{2}{|c|}{ VFW-11 } & \multicolumn{2}{|c|}{ VFW-12 } & \multicolumn{2}{|c|}{ VFW-14 } \\
\hline & & & $\begin{array}{c}\text { Round } \\
1\end{array}$ & $\begin{array}{c}\text { Round } \\
2\end{array}$ & & $\begin{array}{c}\text { Round } \\
1\end{array}$ & \begin{tabular}{|c|} 
Round \\
2
\end{tabular} & Round 1 & $\begin{array}{c}\text { Round } \\
2\end{array}$ & & Round 1 & \begin{tabular}{|c|} 
Round \\
2
\end{tabular} & \begin{tabular}{|c|} 
Round \\
1
\end{tabular} & \begin{tabular}{|c|} 
Round \\
2
\end{tabular} & $\begin{array}{c}\text { Round } \\
1\end{array}$ & $\begin{array}{c}\text { Round } \\
2\end{array}$ \\
\hline \multirow{6}{*}{ Week 1} & Sample Date & $5 / 8 / 00$ & $5 / 8 / 00$ & 10/10/00 & $\mathrm{N} / \mathrm{A}$ & $5 / 8 / 00$ & $10 / 10 / 00$ & $5 / 8 / 00$ & $10 / 10 / 00$ & $10 / 10 / 00$ & $5 / 8 / 00$ & $10 / 10 / 00$ & $5 / 8 / 00$ & $10 / 10 / 00$ & $5 / 8 / 00$ & $10 / 10 / 00$ \\
\hline & pH (standard units) & 7.32 & 6.89 & 7.02 & $\mathrm{~N} / \mathrm{A}$ & 7.10 & 7.03 & 6.90 & 7.08 & 7.08 & 7.10 & 6.98 & 7.00 & 6.93 & 6.82 & 6.93 \\
\hline & Specific Conductance & 3140 & 3890 & 4350 & $\mathrm{~N} / \mathrm{A}$ & 1000 & 1420 & 1580 & 1900 & 1900 & 1640 & 2030 & 1860 & 2270 & 2480 & 2540 \\
\hline & Temperature $\left({ }^{\circ} \mathrm{C}\right)$ & 12.5 & 13.3 & 13.4 & $\mathrm{~N} / \mathrm{A}$ & 11.3 & 12.6 & 12.3 & 14.3 & 14.3 & 12.7 & 12.7 & 12.2 & 13.9 & 13.1 & 13.7 \\
\hline & $\mathrm{TOX}(\mathrm{Fg} / \mathrm{L})$ & $20 U$ & $20 U$ & $20 U$ & $\mathrm{~N} / \mathrm{A}$ & $20 U$ & $20 U$ & $20 U$ & $20 U$ & $20 U$ & $20 U$ & $20 U$ & $20 U$ & $20 U$ & $20 U$ & $20 U$ \\
\hline & TOC (mg/L) & 5.4 & 1.7 & 3.0 & $\mathrm{~N} / \mathrm{A}$ & 8.4 & 1.5 & 2.0 & 3.0 & 3.1 & $1.0 \mathrm{U}$ & 1.2 & 10 & 6.5 & 1.5 & 2.4 \\
\hline \multirow{6}{*}{ Week 2} & Sample Date & $\mathrm{N} / \mathrm{A}$ & $5 / 15 / 00$ & 10/16/00 & $\mathrm{N} / \mathrm{A}$ & $5 / 15 / 00$ & 10/16/00 & $5 / 15 / 00$ & $10 / 16 / 00$ & $\mathrm{~N} / \mathrm{A}$ & $5 / 15 / 00$ & $10 / 16 / 00$ & $5 / 15 / 00$ & $10 / 16 / 00$ & $5 / 15 / 00$ & $10 / 16 / 00$ \\
\hline & pH (standard units) & N/A & 7.02 & 6.76 & $\mathrm{~N} / \mathrm{A}$ & 6.94 & 7.15 & 6.49 & 6.29 & $\mathrm{~N} / \mathrm{A}$ & 6.78 & 7.06 & 6.64 & 7.12 & NS & 6.62 \\
\hline & Specific Conductance & $\mathrm{N} / \mathrm{A}$ & 4400 & 3920 & $\mathrm{~N} / \mathrm{A}$ & 1210 & 1320 & 1940 & 2120 & $\mathrm{~N} / \mathrm{A}$ & 1820 & 1800 & 2010 & 2010 & 2810 & 2620 \\
\hline & Temperature $\left({ }^{0} \mathrm{C}\right)$ & $\mathrm{N} / \mathrm{A}$ & 12.8 & 14.3 & $\mathrm{~N} / \mathrm{A}$ & 11.3 & 13.5 & 12.2 & 14.6 & $\mathrm{~N} / \mathrm{A}$ & 12.4 & 13.3 & 12.0 & 14.1 & 12.6 & 14.4 \\
\hline & $\mathrm{TOX}(\mathrm{Fg} / \mathrm{L})$ & $\mathrm{N} / \mathrm{A}$ & $20 \mathrm{U}$ & $20 \mathrm{U}$ & $\mathrm{N} / \mathrm{A}$ & $20 \mathrm{U}$ & $20 \mathrm{U}$ & $20 \mathrm{U}$ & $20 \mathrm{U}$ & $\mathrm{N} / \mathrm{A}$ & $20 \mathrm{U}$ & $20 U$ & $20 U$ & $20 \mathrm{U}$ & $20 \mathrm{U}$ & $20 \mathrm{U}$ \\
\hline & TOC (mg/L) & $\mathrm{N} / \mathrm{A}$ & 3.4 & 2.9 & $\mathrm{~N} / \mathrm{A}$ & 1.4 & 1.6 & 2.8 & 3.7 & $\mathrm{~N} / \mathrm{A}$ & 2.0 & 2.3 & 5.1 & 6.0 & 2.8 & 2.6 \\
\hline \multirow{6}{*}{ Week 3} & Sample Date & $\mathrm{N} / \mathrm{A}$ & $5 / 22 / 00$ & $10 / 23 / 00$ & $\mathrm{~N} / \mathrm{A}$ & $5 / 22 / 00$ & $10 / 23 / 00$ & $5 / 22 / 00$ & $10 / 23 / 00$ & N/A & $5 / 22 / 00$ & $10 / 23 / 00$ & $5 / 22 / 00$ & $10 / 23 / 00$ & $5 / 22 / 00$ & $10 / 23 / 00$ \\
\hline & $\mathrm{pH}$ (standard units) & $\mathrm{N} / \mathrm{A}$ & 6.92 & 7.01 & $\mathrm{~N} / \mathrm{A}$ & 7.25 & 7.17 & 7.15 & 6.08 & $\mathrm{~N} / \mathrm{A}$ & 7.18 & 7.10 & 7.10 & 7.04 & 6.90 & 6.64 \\
\hline & Specific Conductance & $\mathrm{N} / \mathrm{A}$ & 4150 & 3720 & $\mathrm{~N} / \mathrm{A}$ & 1170 & 1270 & 1760 & 2010 & N/A & 1700 & 1730 & 2010 & 1980 & 2730 & 2530 \\
\hline & Temperature $\left({ }^{\circ} \mathrm{C}\right)$ & $\mathrm{N} / \mathrm{A}$ & 12.6 & 13.3 & $\mathrm{~N} / \mathrm{A}$ & 11.8 & 12.6 & 12.9 & 14.2 & $\mathrm{~N} / \mathrm{A}$ & 12.6 & 12.6 & 12.6 & 13.8 & 12.7 & 14.2 \\
\hline & $\mathrm{TOX}(\mathrm{Fg} / \mathrm{L})$ & N/A & $20 \mathrm{U}$ & $20 \mathrm{U}$ & N/A & $20 \mathrm{U}$ & $20 \mathrm{U}$ & $20 \mathrm{U}$ & $20 \mathrm{U}$ & N/A & $20 \mathrm{U}$ & $20 U$ & $20 U$ & $20 U$ & $20 \mathrm{U}$ & $20 U$ \\
\hline & $\mathrm{TOC}(\mathrm{mg} / \mathrm{L})$ & $\mathrm{N} / \mathrm{A}$ & 3.0 & 3.1 & $\mathrm{~N} / \mathrm{A}$ & 1.3 & 2.5 & 2.3 & 3.6 & $\mathrm{~N} / \mathrm{A}$ & 1.5 & 2.3 & 4.6 & 6.4 & 2.3 & 3.2 \\
\hline \multirow{6}{*}{ Week 4} & Sample Date & $\mathrm{N} / \mathrm{A}$ & $5 / 30 / 00$ & $10 / 30 / 00$ & 10/30/00 & $5 / 30 / 00$ & $10 / 30 / 00$ & $5 / 30 / 00$ & $10 / 30 / 00$ & $5 / 30 / 00$ & $5 / 30 / 00$ & 10/30/00 & $5 / 30 / 00$ & $10 / 30 / 00$ & $5 / 30 / 00$ & $10 / 30 / 00$ \\
\hline & $\mathrm{pH}$ (standard units) & $\mathrm{N} / \mathrm{A}$ & 6.98 & 6.77 & 6.77 & 7.10 & 7.34 & 7.12 & 6.02 & 7.12 & 7.21 & 7.09 & 7.12 & 6.94 & 6.96 & 6.57 \\
\hline & Specific Conductance & $\mathrm{N} / \mathrm{A}$ & 4550 & 1860 & 1860 & 890 & 1490 & 2100 & 2170 & 2100 & 1860 & 1990 & 2180 & 2300 & 3080 & 2770 \\
\hline & Temperature $\left({ }^{\circ} \mathrm{C}\right)$ & $\mathrm{N} / \mathrm{A}$ & 12.9 & 13.3 & 13.3 & 11.2 & 13.0 & 12.6 & 14.0 & 12.6 & 12.8 & 13.2 & 12.4 & 14.1 & 13.2 & 13.6 \\
\hline & $\mathrm{TOX}(\mathrm{Fg} / \mathrm{L})$ & $\mathrm{N} / \mathrm{A}$ & $20 \mathrm{U}$ & $20 U$ & $20 \mathrm{U}$ & $20 U$ & $20 \mathrm{U}$ & $20 \mathrm{U}$ & $20 \mathrm{U}$ & $20 U$ & $20 U$ & $20 U$ & $20 U$ & $20 \mathrm{U}$ & $20 U$ & $20 \mathrm{U}$ \\
\hline & TOC $(\mathrm{mg} / \mathrm{L})$ & $\mathrm{N} / \mathrm{A}$ & 2.3 & 3.0 & 2.7 & 1.4 & 2.2 & 2.1 & 4.2 & 2.2 & 1.3 & 2.8 & 4.6 & 7.4 & 2.2 & 3.2 \\
\hline \multirow{5}{*}{$\begin{array}{l}2000 \\
\text { Range }\end{array}$} & $\mathrm{pH}$ (standard unit) & $\mathrm{N} / \mathrm{A}$ & \multicolumn{2}{|c|}{$6.76-7.02$} & $\mathrm{~N} / \mathrm{A}$ & \multicolumn{2}{|c|}{$6.94-7.34$} & \multicolumn{2}{|c|}{$6.02-7.15$} & $\mathrm{~N} / \mathrm{A}$ & \multicolumn{2}{|c|}{$6.78-7.21$} & \multicolumn{2}{|c|}{$6.64-7.12$} & \multicolumn{2}{|c|}{$6.57-6.96$} \\
\hline & Specific Conductance & $\mathrm{N} / \mathrm{A}$ & \multirow{2}{*}{\multicolumn{2}{|c|}{$\frac{1860-4550}{126-143}$}} & $\mathrm{~N} / \mathrm{A}$ & \multicolumn{2}{|c|}{$890-1490$} & $1580-$ & 2170 & $\mathrm{~N} / \mathrm{A}$ & $1640-2$ & 2030 & 1860 - & -2300 & 2480 & -3080 \\
\hline & Temperature $\left({ }^{\circ} \mathrm{C}\right)$ & $\mathrm{N} / \mathrm{A}$ & & & $\mathrm{N} / \mathrm{A}$ & 11.2 & -13.5 & $12.2-$ & 14.6 & N/A & $12.4-1$ & 13.3 & $12.0-$ & -14.1 & 12.6 & -14.4 \\
\hline & TOX (Fg/L) & $\mathrm{N} / \mathrm{A}$ & 20 & $U$ & $\mathrm{~N} / \mathrm{A}$ & 20 & $U$ & 20 & $U$ & $\mathrm{~N} / \mathrm{A}$ & 201 & & 20 & $\mathrm{U}$ & & 0 \\
\hline & $\mathrm{TOC}(\mathrm{mg} / \mathrm{L})$ & $\mathrm{N} / \mathrm{A}$ & 1.7. & -3.1 & $\mathrm{~N} / \mathrm{A}$ & 1.3. & -8.4 & $2.0-$ & 4.2 & $\mathrm{~N} / \mathrm{A}$ & $1.0 \mathrm{U}$ & & 4.6 & -10 & 1.5 & \\
\hline
\end{tabular}


Table 12. NETL-PGH 2000 Groundwater Detection Monitoring Program

Results of Analysis - Groundwater Samples, Main Plateau - Groundwater Characteristics Constituents

\begin{tabular}{|c|c|c|c|c|c|c|c|c|c|c|c|c|c|}
\hline \multirow{3}{*}{$\begin{array}{l}\text { Constituent } \\
\text { Sampling Date }\end{array}$} & \multicolumn{13}{|c|}{ Well Number and Sample Date } \\
\hline & \multicolumn{2}{|c|}{ MPW-1 } & \multicolumn{2}{|c|}{ MPW-2 } & \multirow{2}{*}{\begin{tabular}{|c|} 
MPW-2-1 \\
$10 / 10 / 00$ \\
\end{tabular}} & \multicolumn{2}{|c|}{ MPW-4 } & \multirow{2}{*}{$\frac{M P W-4-1}{10 / 11 / 00}$} & \multicolumn{2}{|c|}{ MPW-4D } & \multirow{2}{*}{\begin{tabular}{|c|} 
MPW-4D1 \\
$5 / 9 / 00$
\end{tabular}} & \multicolumn{2}{|c|}{ MPW-7 } \\
\hline & $5 / 9 / 00$ & $10 / 11 / 00$ & $5 / 8 / 00$ & $10 / 10 / 00$ & & $5 / 9 / 00$ & $10 / 11 / 00$ & & $5 / 9 / 00$ & $10 / 11 / 00$ & & $5 / 9 / 00$ & $10 / 11 / 00$ \\
\hline \multicolumn{14}{|c|}{ Inorganics (Fg/L) } \\
\hline Aluminum & ND & ND & $\mathrm{ND}$ & ND & ND & ND & ND & $\mathrm{N} / \mathrm{A}$ & ND & ND & ND & ND & ND \\
\hline Boron & ND & ND & ND & ND & ND & ND & ND & $\mathrm{N} / \mathrm{A}$ & ND & ND & ND & ND & ND \\
\hline Calcium & 330000 & 380000 & 310000 & 370000 & 350000 & 250000 & 220000 & $\mathrm{~N} / \mathrm{A}$ & 3800 & 4900 & 4900 & 280000 & 120000 \\
\hline Iron & ND & ND & 2600 & ND & ND & ND & 520 & $\mathrm{~N} / \mathrm{A}$ & ND & ND & ND & 1500 & ND \\
\hline Magnesium & 180000 & 290000 & 72000 & 81000 & 79000 & 98000 & 81000 & $\mathrm{~N} / \mathrm{A}$ & 720 & 890 & 740 & 39000 & 15000 \\
\hline Manganese & 44 & 41 & 1400 & 1500 & 1500 & 100 & 290 & $\mathrm{~N} / \mathrm{A}$ & 27 & $\mathrm{ND}$ & 23 & 210 & 66 \\
\hline Nickel & 390 & 440 & 370 & ND & NAL & 320 & 430 & $\mathrm{~N} / \mathrm{A}$ & ND & ND & ND & 1900 & 490 \\
\hline Phosphorus & ND & 51 & $\mathrm{ND}$ & 25 & $\mathrm{NAL}$ & ND & ND & $\mathrm{N} / \mathrm{A}$ & ND & $\mathrm{ND}$ & ND & ND & ND \\
\hline Potassium & 3600 & 4100 & 2600 & 3000 & 2800 & 5300 & 3800 & $\mathrm{~N} / \mathrm{A}$ & $\mathrm{ND}$ & ND & $\mathrm{ND}$ & 4700 & 3300 \\
\hline Silicon & 3600 & 3200 & 3600 & 3700 & 3500 & 4200 & 3400 & $\mathrm{~N} / \mathrm{A}$ & 3600 & 3500 & 3800 & 4200 & 4400 \\
\hline Sodium & 92000 & 92000 & 190000 & 200000 & 190000 & 100000 & 77000 & $\mathrm{~N} / \mathrm{A}$ & 210000 & 230000 & 210000 & 290000 & 130000 \\
\hline Strontium & 1400 & 1400 & 900 & 620 & 600 & 1000 & 790 & $\mathrm{~N} / \mathrm{A}$ & 150 & 130 & 160 & 600 & 220 \\
\hline \multicolumn{14}{|c|}{ Quality Parameters (mg/L) } \\
\hline Chloride & 1000 & 950 & 910 & 870 & $\mathrm{~N} / \mathrm{A}$ & 640 & 460 & 440 & 97 & 130 & $\mathrm{~N} / \mathrm{A}$ & 720 & 230 \\
\hline Fluoride & 0.15 & 0.12 & 0.087 & 0.069 & $\mathrm{~N} / \mathrm{A}$ & 0.17 & 0.14 & 0.13 & 1.6 & 1.7 & $\mathrm{~N} / \mathrm{A}$ & 0.21 & 0.20 \\
\hline Nitrate & 0.20 & 0.20 & 0.61 & 0.93 & $\mathrm{~N} / \mathrm{A}$ & 0.13 & 0.51 & $\mathrm{~N} / \mathrm{A}$ & ND & 0.26 & $\mathrm{~N} / \mathrm{A}$ & 0.53 & 0.81 \\
\hline Sulfate & 210 & 220 & 180 & 160 & $\mathrm{~N} / \mathrm{A}$ & 160 & 99 & 88 & 23 & 20 & $\mathrm{~N} / \mathrm{A}$ & 340 & 120 \\
\hline Total Dissolved Solids & 2600 & NS & 2300 & NS & $\mathrm{N} / \mathrm{A}$ & 2000 & NS & NS & 600 & NS & $\mathrm{N} / \mathrm{A}$ & 2100 & NS \\
\hline Total Alkalinity (Bicarbonate) & 220 & 240 & 170 & 170 & $\mathrm{~N} / \mathrm{A}$ & 230 & 180 & 180 & 330 & 350 & $\mathrm{~N} / \mathrm{A}$ & 140 & 230 \\
\hline Total Alkalinity (Carbanate) & $\mathrm{ND}$ & ND & $\mathrm{ND}$ & $\mathrm{ND}$ & $\mathrm{N} / \mathrm{A}$ & $\mathrm{ND}$ & $\mathrm{ND}$ & ND & ND & ND & $\mathrm{N} / \mathrm{A}$ & ND & ND \\
\hline
\end{tabular}

$\mathrm{N} / \mathrm{A}=$ not applicable; NS = not sampled; ND = not detected; NAL = Not Analyzed. 
Table 12. NETL-PGH 2000 Groundwater Detection Monitoring Program

Results of Analysis - Groundwater Samples, Main Plateau - Groundwater Characteristics Constituents

(continued)

\begin{tabular}{|c|c|c|c|c|c|c|c|c|c|c|c|c|c|c|c|}
\hline \multirow{3}{*}{ Constituent } & \multirow{2}{*}{\multicolumn{2}{|c|}{ MPW-7D }} & & & & & & & & & & & \multicolumn{3}{|c|}{ Well Number and Sample Date } \\
\hline & & & \multicolumn{2}{|c|}{ MPW-8 } & \multicolumn{2}{|c|}{ MPW-9 } & \multirow{2}{*}{\begin{tabular}{|c|} 
MPW-9-1 \\
$10 / 11 / 00$ \\
\end{tabular}} & \multicolumn{2}{|c|}{ MPW-10 } & \multirow{2}{*}{\begin{tabular}{|c|} 
MPW-10-1 \\
$5 / 9 / 00$ \\
\end{tabular}} & \multicolumn{2}{|c|}{ MPW-11 } & MPW-11-1 & \multicolumn{2}{|c|}{ MPW-12 } \\
\hline & $5 / 9 / 00$ & $10 / 11 / 00$ & $5 / 9 / 00$ & $10 / 11 / 00$ & $5 / 9 / 00$ & $10 / 11 / 00$ & & $5 / 9 / 00$ & $10 / 11 / 00$ & & $5 / 9 / 00$ & $10 / 11 / 00$ & $5 / 9 / 00$ & $5 / 8 / 00$ & $10 / 10 / 00$ \\
\hline \multicolumn{16}{|l|}{ Inorganics (Fg/L) } \\
\hline Aluminum & ND & $\mathrm{ND}$ & $\mathrm{ND}$ & ND & ND & ND & $\mathrm{N} / \mathrm{A}$ & ND & ND & $\mathrm{N} / \mathrm{A}$ & ND & ND & $\mathrm{N} / \mathrm{A}$ & ND & ND \\
\hline Boron & ND & ND & ND & ND & ND & ND & $\mathrm{N} / \mathrm{A}$ & ND & ND & $\mathrm{N} / \mathrm{A}$ & ND & ND & $\mathrm{N} / \mathrm{A}$ & ND & ND \\
\hline Calcium & 150000 & 200000 & 370000 & 390000 & 79000 & 79000 & $\mathrm{~N} / \mathrm{A}$ & 2100 & 2200 & $\mathrm{~N} / \mathrm{A}$ & 230000 & 210000 & $\mathrm{~N} / \mathrm{A}$ & NAL & 570000 \\
\hline Iron & ND & ND & 760 & 10000 & ND & ND & $\mathrm{N} / \mathrm{A}$ & ND & ND & $\mathrm{N} / \mathrm{A}$ & ND & ND & $\mathrm{N} / \mathrm{A}$ & ND & ND \\
\hline Manganese & 85 & $\mathrm{ND}$ & 570 & 930 & ND & 13 & $\mathrm{~N} / \mathrm{A}$ & ND & ND & $\mathrm{N} / \mathrm{A}$ & 43 & 54 & $\mathrm{~N} / \mathrm{A}$ & 43 & 74 \\
\hline Nickel & 370 & 76 & 470 & 4700 & 46 & 90 & $\mathrm{~N} / \mathrm{A}$ & ND & ND & $\mathrm{N} / \mathrm{A}$ & ND & $\mathrm{ND}$ & $\mathrm{N} / \mathrm{A}$ & ND & ND \\
\hline Phosphorus & ND & ND & ND & ND & ND & ND & $\mathrm{N} / \mathrm{A}$ & ND & ND & $\mathrm{N} / \mathrm{A}$ & ND & ND & $\mathrm{N} / \mathrm{A}$ & ND & ND \\
\hline Potassium & 1800 & 2500 & 4600 & 5300 & ND & 1200 & $\mathrm{~N} / \mathrm{A}$ & ND & ND & $\mathrm{N} / \mathrm{A}$ & 3700 & 3900 & $\mathrm{~N} / \mathrm{A}$ & 3500 & 4200 \\
\hline Silicon & 4300 & 3600 & 4300 & 4200 & 3600 & 3400 & $\mathrm{~N} / \mathrm{A}$ & 4200 & 3900 & $\mathrm{~N} / \mathrm{A}$ & 3400 & 3200 & $\mathrm{~N} / \mathrm{A}$ & 3400 & 3400 \\
\hline Sodium & 70000 & 110000 & 220000 & 220000 & 74000 & 85000 & $\mathrm{~N} / \mathrm{A}$ & 180000 & 190000 & $\mathrm{~N} / \mathrm{A}$ & 180000 & 170000 & $\mathrm{~N} / \mathrm{A}$ & NAL & 540000 \\
\hline Strontium & 1600 & 1100 & 860 & 880 & 1900 & 1600 & $\mathrm{~N} / \mathrm{A}$ & 83 & 75 & $\mathrm{~N} / \mathrm{A}$ & 580 & 460 & $\mathrm{~N} / \mathrm{A}$ & 660 & 750 \\
\hline Chloride & 300 & 420 & 1100 & 950 & 96 & 92 & $\mathrm{~N} / \mathrm{A}$ & 65 & 65 & $\mathrm{~N} / \mathrm{A}$ & 650 & 490 & 650 & 260 & 2000 \\
\hline Fluoride & 0.13 & 0.080 & 0.10 & 0.087 & 0.15 & 0.14 & $\mathrm{~N} / \mathrm{A}$ & 0.40 & 0.40 & $\mathrm{~N} / \mathrm{A}$ & 0.18 & 0.20 & 0.19 & 0.11 & 0.10 \\
\hline Nitrate & 0.21 & 0.29 & 0.22 & 0.16 & 0.20 & ND & 0.23 & ND & ND & ND & 0.75 & 1.0 & $\mathrm{~N} / \mathrm{A}$ & 1.1 & 0.63 \\
\hline Sulfate & 93 & 130 & 200 & 200 & 93 & 70 & $\mathrm{~N} / \mathrm{A}$ & 16 & 14 & $\mathrm{~N} / \mathrm{A}$ & 250 & 240 & 240 & 230 & 210 \\
\hline Total Dissolved Solids & 1000 & NS & 2500 & NS & 550 & NS & $\mathrm{N} / \mathrm{A}$ & 480 & NS & $\mathrm{N} / \mathrm{A}$ & 18000 & NS & 1800 & 5200 & NS \\
\hline Total Alkalinity (Bicarbonate) & 260 & 210 & 180 & 270 & 220 & 250 & $\mathrm{~N} / \mathrm{A}$ & 300 & 320 & $\mathrm{~N} / \mathrm{A}$ & 130 & 130 & $\mathrm{ND}$ & 130 & 140 \\
\hline Total Alkalinity (Carbonate) & ND & ND & ND & ND & ND & ND & $\mathrm{N} / \mathrm{A}$ & 15 & 6.1 & $\mathrm{~N} / \mathrm{A}$ & ND & ND & ND & ND & ND \\
\hline
\end{tabular}

$\mathrm{N} / \mathrm{A}=$ not applicable; NS = not sampled; ND = not detected; NAL = Not Analyzed. 
Table 13. NETL-PGH 2000 Groundwater Detection Monitoring Program

Results of Analysis - Groundwater Samples, Valley Fill - Groundwater Characteristics Constituents

\begin{tabular}{|c|c|c|c|c|c|c|c|c|c|c|c|c|c|c|c|}
\hline \multirow{3}{*}{$\begin{array}{l}\text { Constituent } \\
\text { Date Sampled }\end{array}$} & \multicolumn{15}{|c|}{ Well Number and Sample Date } \\
\hline & \multicolumn{2}{|c|}{ VFW-1 } & \multirow{2}{*}{$\frac{\text { VFW-1-1 }}{5 / 8 / 00}$} & \multicolumn{2}{|c|}{ VFW-2 } & \multicolumn{2}{|c|}{ VFW-3 } & \multicolumn{2}{|c|}{ VFW-4 } & \multirow{2}{*}{\begin{tabular}{|l|} 
VFW-4-1 \\
$10 / 10 / 00$ \\
\end{tabular}} & \multicolumn{2}{|c|}{ VFW-5 } & \multirow{2}{*}{$\frac{\text { VFW-5-1 }}{5 / 8 / 00}$} & \multicolumn{2}{|c|}{ VFW-5-6 } \\
\hline & $5 / 8 / 00$ & $10 / 10 / 00$ & & $5 / 8 / 00$ & $10 / 10 / 00$ & $5 / 8 / 00$ & $10 / 10 / 00$ & $5 / 8 / 00$ & $10 / 10 / 00$ & & $5 / 8 / 00$ & $10 / 10 / 00$ & & $5 / 8 / 00$ & $10 / 10 / 00$ \\
\hline \multicolumn{16}{|l|}{ Inorganics (Fg/L) } \\
\hline Aluminum & ND & ND & $\mathrm{N} / \mathrm{A}$ & ND & ND & ND & ND & ND & ND & ND & ND & ND & $\mathrm{N} / \mathrm{A}$ & ND & ND \\
\hline Boron & ND & ND & $\mathrm{N} / \mathrm{A}$ & ND & ND & ND & ND & ND & ND & ND & ND & ND & $\mathrm{N} / \mathrm{A}$ & ND & ND \\
\hline Calcium & 6600 & 6800 & $\mathrm{~N} / \mathrm{A}$ & NAL & 300000 & 230000 & 270000 & 240000 & 280000 & 210000 & 250000 & 270000 & $\mathrm{~N} / \mathrm{A}$ & 260000 & 290000 \\
\hline Iron & 300 & $\mathrm{ND}$ & $\mathrm{N} / \mathrm{A}$ & 1100 & 2700 & $\mathrm{ND}$ & $\mathrm{ND}$ & 280 & $\mathrm{ND}$ & 330 & 750 & $\mathrm{ND}$ & $\mathrm{N} / \mathrm{A}$ & 1100 & 800 \\
\hline Magnesium & 1900 & 2100 & $\mathrm{~N} / \mathrm{A}$ & 73000 & 61000 & 94000 & 110000 & 78000 & 97000 & 70000 & 34000 & 38000 & $\mathrm{~N} / \mathrm{A}$ & 50000 & 51000 \\
\hline Manganese & 14 & 14 & $\mathrm{~N} / \mathrm{A}$ & 2600 & 2100 & 39 & 58 & 94 & 58 & 110 & ND & ND & $\mathrm{N} / \mathrm{A}$ & 550 & 610 \\
\hline Nickel & ND & ND & $\mathrm{N} / \mathrm{A}$ & ND & ND & 280 & 280 & 130 & 220 & 100 & 94 & $\mathrm{ND}$ & $\mathrm{N} / \mathrm{A}$ & ND & ND \\
\hline Phosphorus & ND & 77 & $\mathrm{~N} / \mathrm{A}$ & ND & ND & ND & ND & ND & ND & ND & $\mathrm{ND}$ & ND & $\mathrm{N} / \mathrm{A}$ & ND & $\mathrm{ND}$ \\
\hline Potassium & 1400 & 1300 & $\mathrm{~N} / \mathrm{A}$ & 13000 & 4400 & 4300 & 4900 & 3300 & 4200 & 3200 & 4600 & 5200 & $\mathrm{~N} / \mathrm{A}$ & 8500 & 11000 \\
\hline Silicon & 4900 & 4900 & $\mathrm{~N} / \mathrm{A}$ & 4900 & 8900 & 4300 & 4100 & 5600 & 4800 & 5400 & 9400 & 8800 & $\mathrm{~N} / \mathrm{A}$ & 5400 & 6400 \\
\hline Sodium & 250000 & 220000 & $\mathrm{~N} / \mathrm{A}$ & 160000 & 160000 & 110000 & 110000 & 20000 & 23000 & 19000 & $\overline{N A L}$ & 400000 & $\mathrm{~N} / \mathrm{A}$ & $\overline{N A L}$ & 350000 \\
\hline Strontium & 440 & 430 & $\mathrm{~N} / \mathrm{A}$ & 5800 & 2600 & 1200 & 1300 & 1800 & 1700 & 1600 & 620 & 600 & $\mathrm{~N} / \mathrm{A}$ & 1100 & 1000 \\
\hline \multicolumn{16}{|l|}{$\begin{array}{r}\text { Quality Parameters } \\
(\mathrm{mg} / \mathrm{L}) \\
\end{array}$} \\
\hline Chloride & 21 & 16 & 14 & 920 & 180 & 600 & 630 & 450 & 480 & 460 & 850 & 740 & $\mathrm{~N} / \mathrm{A}$ & 1000 & 710 \\
\hline Fluoride & 1.5 & 1.4 & 1.4 & 0.75 & 1.4 & 0.20 & 0.16 & 0.19 & 0.14 & 0.15 & 0.90 & 0.80 & $\mathrm{~N} / \mathrm{A}$ & 1.0 & 1.0 \\
\hline Nitrate & ND & ND & $\mathrm{N} / \mathrm{A}$ & ND & ND & 1.9 & 1.4 & 0.11 & 0.12 & $\mathrm{~N} / \mathrm{A}$ & 0.91 & 0.70 & 0.90 & ND & 0.054 \\
\hline Sulfate & ND & 1.4 & $\mathrm{ND}$ & 650 & 810 & 180 & 160 & 100 & 94 & 88 & 310 & 290 & $\mathrm{~N} / \mathrm{A}$ & 380 & 440 \\
\hline Total Dissolved Solids & 580 & NS & 560 & 3000 & NS & 1800 & NS & 1600 & NS & NS & 2300 & NS & $\mathrm{N} / \mathrm{A}$ & 2500 & NS \\
\hline Total Alkalinity (Bicarbonate) & 540 & 520 & $\mathrm{~N} / \mathrm{A}$ & 180 & 230 & 300 & 310 & 320 & 320 & 320 & 200 & 250 & $\mathrm{~N} / \mathrm{A}$ & 90 & 91 \\
\hline Total Alkalinity (Carbanate) & ND & ND & $\mathrm{N} / \mathrm{A}$ & ND & ND & $\mathrm{ND}$ & $\mathrm{ND}$ & $\mathrm{ND}$ & $\mathrm{ND}$ & ND & $\mathrm{ND}$ & ND & $\mathrm{N} / \mathrm{A}$ & $\mathrm{ND}$ & $\mathrm{ND}$ \\
\hline
\end{tabular}

$\mathrm{N} / \mathrm{A}$ = not applicable; NS = not sampled; ND = not detected; NAL = Not Analyzed. 
Table 13. NETL-PGH 2000 Groundwater Detection Monitoring Program Results of Analysis - Groundwater Samples, Valley Fill - Groundwater Characteristics Constituents

(continued)

\begin{tabular}{|c|c|c|c|c|c|c|c|c|c|c|c|c|c|c|}
\hline \multirow[b]{2}{*}{$\begin{array}{c}\text { Constituent } \\
\text { Sample Date }\end{array}$} & \multicolumn{2}{|c|}{ VFW-7 } & \multirow{2}{*}{\begin{tabular}{|l|} 
VFW-7-1 \\
$10 / 10 / 00$ \\
\end{tabular}} & \multicolumn{2}{|c|}{ VFW 9} & \multicolumn{2}{|c|}{ VFW-10 } & \multicolumn{2}{|c|}{ VFW-11 } & \multirow{2}{*}{\begin{tabular}{|c|} 
VFW-11-1 \\
$10 / 10 / 00$ \\
\end{tabular}} & \multicolumn{2}{|c|}{ VFW-12 } & \multicolumn{2}{|c|}{ VFW-14 } \\
\hline & $5 / 8 / 00$ & $10 / 10 / 00$ & & $5 / 8 / 00$ & $10 / 10 / 00$ & $5 / 8 / 00$ & $10 / 10 / 00$ & $5 / 8 / 00$ & $10 / 10 / 00$ & & $5 / 8 / 00$ & $10 / 10 / 00$ & $5 / 8 / 00$ & $10 / 10 / 00$ \\
\hline \multicolumn{15}{|c|}{ Inorganics (Fg/L) } \\
\hline Aluminum & ND & $\mathrm{ND}$ & $\mathrm{ND}$ & $\mathrm{ND}$ & ND & ND & ND & ND & ND & $\mathrm{N} / \mathrm{A}$ & ND & ND & ND & ND \\
\hline Boron & ND & ND & $\mathrm{ND}$ & $\mathrm{ND}$ & ND & ND & ND & $\mathrm{ND}$ & ND & $\mathrm{N} / \mathrm{A}$ & ND & ND & ND & ND \\
\hline Calcium & 360000 & 390000 & 370000 & 130000 & 210000 & 260000 & 280000 & 230000 & 250000 & $\mathrm{~N} / \mathrm{A}$ & 230000 & 240000 & 280000 & 320000 \\
\hline Iron & 3200 & 2800 & 2600 & $\mathrm{ND}$ & $\mathrm{ND}$ & ND & $\mathrm{ND}$ & ND & $\mathrm{ND}$ & $\mathrm{N} / \mathrm{A}$ & $\overline{N D}$ & ND & 660 & 550 \\
\hline Magnesium & 78000 & 84000 & 80000 & 29000 & 39000 & 59000 & 55000 & 60000 & 64000 & $\mathrm{~N} / \mathrm{A}$ & 66000 & 67000 & 61000 & 66000 \\
\hline Manganese & 1400 & 1400 & 1400 & 10 & 11 & 2600 & 2600 & 32 & 300 & $\mathrm{~N} / \mathrm{A}$ & 93 & 360 & 1400 & 1800 \\
\hline Nickel & ND & ND & NAL & 120 & 110 & 48 & ND & 780 & 480 & $\mathrm{~N} / \mathrm{A}$ & 570 & 270 & ND & ND \\
\hline Phosphorus & ND & 39 & NAL & ND & ND & ND & 39 & ND & ND & $\mathrm{N} / \mathrm{A}$ & ND & ND & ND & ND \\
\hline Potassium & 5500 & 5900 & 5700 & 2200 & 2500 & 5500 & 10000 & 2200 & 2400 & $\mathrm{~N} / \mathrm{A}$ & 3300 & 3900 & 3000 & 3400 \\
\hline Silicon & 5000 & 5000 & 4700 & 3400 & 3400 & 6100 & 6500 & 2900 & 3300 & $\mathrm{~N} / \mathrm{A}$ & 4300 & 5400 & 6100 & 6100 \\
\hline Sodium & NAL & 380000 & 380000 & 55000 & 38000 & NAL & 130000 & 51000 & 76000 & $\mathrm{~N} / \mathrm{A}$ & 120000 & 130000 & NAL & 180000 \\
\hline Strontium & 3200 & 3100 & 3000 & 280 & 300 & 530 & 520 & 920 & 780 & $\mathrm{~N} / \mathrm{A}$ & 2400 & 1800 & 1700 & 1600 \\
\hline \multicolumn{15}{|c|}{ Quality Parameters (mg/L) } \\
\hline Chloride & 1400 & 1200 & $\mathrm{~N} / \mathrm{A}$ & 220 & 260 & 140 & 250 & 440 & 430 & $\mathrm{~N} / \mathrm{A}$ & 410 & 340 & 710 & 600 \\
\hline Fluoride & 0.098 & 0.076 & $\mathrm{~N} / \mathrm{A}$ & 0.085 & 0.078 & 0.44 & 0.71 & 0.12 & 0.091 & $\mathrm{~N} / \mathrm{A}$ & 0.41 & 0.45 & 0.24 & 0.20 \\
\hline Nitrate & 0.38 & ND & $\mathrm{N} / \mathrm{A}$ & 1.4 & 1.2 & 3.4 & 1.0 & 0.082 & 0.078 & 0.086 & 0.38 & 0.22 & 0.060 & ND \\
\hline Sulfate & 130 & 140 & $\mathrm{~N} / \mathrm{A}$ & 180 & 160 & 720 & 560 & 160 & 170 & $\mathrm{~N} / \mathrm{A}$ & 380 & 260 & 320 & 270 \\
\hline Total Dissolved Solids & 3100 & NS & $\mathrm{N} / \mathrm{A}$ & 920 & NS & 1600 & NS & 1500 & NS & $\mathrm{N} / \mathrm{A}$ & 1700 & NS & 2200 & NS \\
\hline Alkalinity (Bicarbonate) & 220 & 230 & $\mathrm{~N} / \mathrm{A}$ & 130 & 150 & 230 & 250 & 180 & 190 & $\mathrm{~N} / \mathrm{A}$ & 280 & 350 & 230 & 260 \\
\hline Alkalinity (Carbonate) & ND & $\mathrm{ND}$ & $\mathrm{N} / \mathrm{A}$ & $\mathrm{ND}$ & ND & $\mathrm{ND}$ & ND & $\mathrm{ND}$ & ND & $\mathrm{N} / \mathrm{A}$ & $\mathrm{ND}$ & $\mathrm{ND}$ & ND & $\mathrm{ND}$ \\
\hline
\end{tabular}

$\mathrm{N} / \mathrm{A}=$ not applicable; NS = not sampled; ND = not detected; NAL = Not Analyzed 
Table 14. NETL-PGH 2000 Groundwater Detection Monitoring Program

Results of Analysis - Groundwater Samples

Main Plateau - Semivolatile Organic Compounds Constituents (Fg/L)

\begin{tabular}{|l|c|c|c|c|}
\hline \multirow{2}{*}{$\begin{array}{c}\text { Constituent } \\
\text { Sample Date }\end{array}$} & \multicolumn{2}{c|}{ Well Number and Sample Date } \\
\cline { 2 - 5 } & $5 / 9 / 00$ & $10 / 11 / 00$ & $5 / 9 / 00$ & $10 / 11 / 00$ \\
\hline 1,2,4-Trichlorobenzene & $\mathrm{ND}$ & $\mathrm{ND}$ & $\mathrm{ND}$ & $\mathrm{ND}$ \\
\hline 1,2-Dichlorobenzene & $\mathrm{ND}$ & $\mathrm{ND}$ & $\mathrm{ND}$ & $\mathrm{ND}$ \\
\hline 1,3-Dichlorobenzene & $\mathrm{ND}$ & $\mathrm{ND}$ & $\mathrm{ND}$ & $\mathrm{ND}$ \\
\hline 1,4-Dichlorobenzene & $\mathrm{ND}$ & $\mathrm{ND}$ & $\mathrm{ND}$ & $\mathrm{ND}$ \\
\hline 2,4,5-Trichlorophenol & $\mathrm{ND}$ & $\mathrm{ND}$ & $\mathrm{ND}$ & $\mathrm{ND}$ \\
\hline 2,4,6-Trichlorophenol & $\mathrm{ND}$ & $\mathrm{ND}$ & $\mathrm{ND}$ & $\mathrm{ND}$ \\
\hline 2,4-Dichlorophenol & $\mathrm{ND}$ & $\mathrm{ND}$ & $\mathrm{ND}$ & $\mathrm{ND}$ \\
\hline 2,4-Dimethylphenol & $\mathrm{ND}$ & $\mathrm{ND}$ & $\mathrm{ND}$ & $\mathrm{ND}$ \\
\hline 2,4-Dinitrophenol & $\mathrm{ND}$ & $\mathrm{ND}$ & $\mathrm{ND}$ & $\mathrm{ND}$ \\
\hline 2,4-Dinitrotoulene & $\mathrm{ND}$ & $\mathrm{ND}$ & $\mathrm{ND}$ & $\mathrm{ND}$ \\
\hline 2,6-Dinitrotoluene & $\mathrm{ND}$ & $\mathrm{ND}$ & $\mathrm{ND}$ & $\mathrm{ND}$ \\
\hline 2-Chloronaphthalene & $\mathrm{ND}$ & $\mathrm{ND}$ & $\mathrm{ND}$ & $\mathrm{ND}$ \\
\hline 2-Chlorophenol & $\mathrm{ND}$ & $\mathrm{ND}$ & $\mathrm{ND}$ & $\mathrm{ND}$ \\
\hline 2-Methylnaphthalene & $\mathrm{ND}$ & $\mathrm{ND}$ & $\mathrm{ND}$ & $\mathrm{ND}$ \\
\hline 2-Methylphenol (o-Cresol) & $\mathrm{ND}$ & $\mathrm{ND}$ & $\mathrm{ND}$ & $\mathrm{ND}$ \\
\hline 2-Nitroaniline & $\mathrm{ND}$ & $\mathrm{ND}$ & $\mathrm{ND}$ & $\mathrm{ND}$ \\
\hline 2-Nitrophenol & $\mathrm{ND}$ & $\mathrm{ND}$ & $\mathrm{ND}$ & $\mathrm{ND}$ \\
\hline 3,3'-Dichlorobenzidine & $\mathrm{ND}$ & $\mathrm{ND}$ & $\mathrm{ND}$ & $\mathrm{ND}$ \\
\hline 3-Nitroaniline & $\mathrm{ND}$ & $\mathrm{ND}$ & $\mathrm{ND}$ & $\mathrm{ND}$ \\
\hline 4,6-Dinitro-2-methlyphenol & $\mathrm{ND}$ & $\mathrm{ND}$ & $\mathrm{ND}$ & $\mathrm{ND}$ \\
\hline 4-Bromophenyl phenyl ether & $\mathrm{ND}$ & $\mathrm{ND}$ & $\mathrm{ND}$ & $\mathrm{ND}$ \\
\hline 4-Chloro-3-methylphenol & $\mathrm{ND}$ & $\mathrm{ND}$ & $\mathrm{ND}$ & $\mathrm{ND}$ \\
\hline 4-Chloroaniline & $\mathrm{ND}$ & $\mathrm{ND}$ & $\mathrm{ND}$ & $\mathrm{ND}$ \\
\hline 4-Chlorodiphenyl ether & $\mathrm{ND}$ & $\mathrm{ND}$ & $\mathrm{ND}$ & $\mathrm{ND}$ \\
\hline 4-Methylphenol (p-Cresol) & $\mathrm{ND}$ & $\mathrm{ND}$ & $\mathrm{ND}$ & $\mathrm{ND}$ \\
\hline 4-Nitroaniline & $\mathrm{ND}$ & $\mathrm{ND}$ & $\mathrm{ND}$ & $\mathrm{ND}$ \\
\hline 4-Nitrophenol & $\mathrm{ND}$ & $\mathrm{ND}$ & $\mathrm{ND}$ & $\mathrm{ND}$ \\
\hline Acenaphthene & $\mathrm{ND}$ & $\mathrm{ND}$ & $\mathrm{ND}$ & $\mathrm{ND}$ \\
\hline Acenaphthylene & $\mathrm{ND}$ & $\mathrm{ND}$ & $\mathrm{ND}$ \\
\hline Anthracene & $\mathrm{ND}$ & $\mathrm{ND}$ & $\mathrm{ND}$ \\
\hline Benzo(a)anthracene & $\mathrm{ND}$ & $\mathrm{ND}$ \\
\hline
\end{tabular}

$\mathrm{ND}=$ not detected 
Table 14. NETL-PGH 2000 Groundwater Detection Monitoring Program

Results of Analysis - Groundwater Samples

Main Plateau - Semivolatile Organic Compounds Constituents (Fg/L)

(continued)

\begin{tabular}{|c|c|c|c|c|}
\hline \multirow{3}{*}{$\begin{array}{l}\text { Constituent } \\
\text { Sample Date }\end{array}$} & \multicolumn{4}{|c|}{ Well Number and Sample Date } \\
\hline & \multicolumn{2}{|c|}{ MPW-1 } & \multicolumn{2}{|c|}{ MPW-7 } \\
\hline & $5 / 9 / 00$ & $10 / 11 / 00$ & $5 / 9 / 00$ & $10 / 11 / 00$ \\
\hline Benzo(b)fluoranthene & ND & ND & ND & ND \\
\hline Benzo(ghi)perylene & ND & ND & ND & ND \\
\hline Benzo(k)fluoranthene & ND & ND & ND & ND \\
\hline Bis(2-chloroethoxyl) methane & ND & ND & ND & ND \\
\hline Bis (2-chloroethyl) ether & ND & ND & ND & ND \\
\hline Bis(2-chloroisopropyl) ether & ND & ND & ND & ND \\
\hline Bis(2-ethylhexyl) phthalate & ND & ND & ND & ND \\
\hline Butyl benzyl phthalate & ND & ND & ND & ND \\
\hline Carbazole & ND & ND & ND & ND \\
\hline Chrysene & ND & ND & ND & ND \\
\hline Di-n-butyl phthalate & ND & ND & ND & ND \\
\hline Di-n-octly phthalate & ND & ND & ND & ND \\
\hline Dibenzo(a,h)anthracene & ND & ND & ND & ND \\
\hline Dibenzofuran & ND & ND & ND & ND \\
\hline Diethyl phthalate & ND & ND & ND & ND \\
\hline Dimethyl phthalate & ND & ND & ND & ND \\
\hline Fluoranthene & $\mathrm{ND}$ & $\mathrm{ND}$ & $\mathrm{ND}$ & ND \\
\hline Fluorene & ND & ND & ND & ND \\
\hline Hexachlorobenzene & ND & ND & ND & ND \\
\hline Hexachlorobutadiene & $\mathrm{ND}$ & $\mathrm{ND}$ & $\mathrm{ND}$ & ND \\
\hline Hexachlorocyclopentadiene & ND & ND & ND & ND \\
\hline Hexachloroethane & ND & ND & ND & ND \\
\hline Indeno(1,2,3-cd)pyrene & ND & ND & ND & ND \\
\hline Isophorone & ND & ND & ND & ND \\
\hline N-Nitroso-Di-n-propylamine & $\mathrm{ND}$ & ND & ND & ND \\
\hline N-nitrosodiphenylamine & ND & ND & ND & ND \\
\hline Naphthalene & ND & ND & ND & ND \\
\hline Nitrobenzene & ND & ND & ND & ND \\
\hline Pentachlorophenol & ND & ND & ND & ND \\
\hline Phenanthrene & ND & ND & ND & ND \\
\hline Phenol & $\mathrm{ND}$ & $\mathrm{ND}$ & ND & ND \\
\hline Pyrene & ND & ND & ND & ND \\
\hline
\end{tabular}

$\mathrm{ND}=$ not detected. 
Table 15. NETL-PGH 2000 Groundwater Detection Monitoring Program Results of Analysis - Groundwater Samples Valley Fill - Semivolatile Organic Compounds Constituents (Fg/L)

\begin{tabular}{|c|c|c|c|c|c|c|}
\hline \multirow{3}{*}{$\begin{array}{l}\text { Constituent } \\
\text { Sample Date }\end{array}$} & \multicolumn{6}{|c|}{ Well Number and Sample Date } \\
\hline & \multicolumn{2}{|c|}{ VFW-2 } & \multirow{2}{*}{\begin{tabular}{|c|} 
VFW-2-1 \\
$5 / 8 / 00$ \\
\end{tabular}} & \multicolumn{2}{|c|}{ VFW-14 } & \multirow{2}{*}{\begin{tabular}{|l|} 
VFW-14-1 \\
$10 / 10 / 00$ \\
\end{tabular}} \\
\hline & $5 / 8 / 00$ & $10 / 10 / 00$ & & $5 / 8 / 00$ & $10 / 10 / 00$ & \\
\hline 1,2,4-Trichlorobenzene & ND & ND & ND & ND & ND & ND \\
\hline 1,2-Dichlorobenzene & ND & ND & ND & ND & ND & ND \\
\hline 1,3-Dichlorobenzene & ND & ND & ND & ND & ND & ND \\
\hline 1,4-Dichlorobenzene & ND & ND & ND & ND & ND & ND \\
\hline 2,4,5-Trichlorophenol & ND & ND & ND & ND & ND & ND \\
\hline 2,4,6-Trichlorophenol & ND & ND & ND & ND & ND & ND \\
\hline 2,4-Dichlorophenol & ND & ND & ND & ND & ND & ND \\
\hline 2,4-Dimethylphenol & ND & ND & ND & ND & ND & ND \\
\hline 2,4-Dinitrophenol & ND & $\mathrm{ND}$ & ND & $\mathrm{ND}$ & ND & ND \\
\hline 2,4-Dinitrotoulene & ND & ND & ND & ND & ND & ND \\
\hline 2,6-Dinitrotoluene & ND & ND & ND & ND & ND & ND \\
\hline 2-Chloronaphthalene & $\mathrm{ND}$ & $\mathrm{ND}$ & $\mathrm{ND}$ & $\mathrm{ND}$ & $\mathrm{ND}$ & $\mathrm{ND}$ \\
\hline 2-Chlorophenol & ND & ND & ND & ND & ND & ND \\
\hline 2-Methylnaphthalene & ND & ND & ND & ND & ND & ND \\
\hline 2-Methylphenol (o-Cresol) & ND & ND & ND & ND & ND & ND \\
\hline 2-Nitroaniline & ND & ND & ND & ND & ND & ND \\
\hline 2-Nitrophenol & $\mathrm{ND}$ & $\mathrm{ND}$ & $\mathrm{ND}$ & $\mathrm{ND}$ & $\mathrm{ND}$ & $\mathrm{ND}$ \\
\hline 3,3'-Dichlorobenzidine & ND & ND & ND & ND & ND & ND \\
\hline 3-Nitroaniline & ND & ND & ND & ND & ND & ND \\
\hline 4,6-Dinitro-2-methlyphenol & ND & ND & ND & ND & ND & ND \\
\hline 4-Bromophenyl phenyl ether & ND & ND & ND & ND & ND & ND \\
\hline 4-Chloro-3-methylphenol & ND & ND & ND & ND & ND & ND \\
\hline 4-Chloroaniline & ND & ND & ND & ND & ND & ND \\
\hline 4-Chlorodiphenyl ether & ND & ND & ND & ND & ND & ND \\
\hline 4-Methylphenol ( $\mathrm{p}$-Cresol) & ND & ND & ND & ND & ND & ND \\
\hline 4-Nitroaniline & ND & ND & ND & ND & ND & ND \\
\hline 4-Nitrophenol & ND & ND & ND & ND & ND & ND \\
\hline Acenaphthene & ND & ND & ND & ND & ND & ND \\
\hline Acenaphthylene & ND & ND & ND & ND & ND & ND \\
\hline Anthracene & ND & ND & ND & ND & ND & ND \\
\hline Benzo(a)anthracene & ND & ND & ND & ND & ND & ND \\
\hline Benzo(a)pyrene & ND & ND & ND & ND & ND & ND \\
\hline
\end{tabular}

$\mathrm{ND}=$ not detected. 
Table 15. NETL-PGH 2000 Groundwater Detection Monitoring Program Results of Analysis - Groundwater Samples Valley Fill - Semivolatile Organic Compounds Constituents (Fg/L)

(continued)

\begin{tabular}{|c|c|c|c|c|c|c|}
\hline \multirow{3}{*}{$\begin{array}{l}\text { Constituent } \\
\text { Sample Date }\end{array}$} & \multicolumn{6}{|c|}{ Well Number and Sample Date } \\
\hline & \multicolumn{2}{|c|}{ VFW-2 } & \multirow{2}{*}{\begin{tabular}{|c|} 
VFW-2-1 \\
$5 / 8 / 00$ \\
\end{tabular}} & \multicolumn{2}{|c|}{ VFW-14 } & \multirow{2}{*}{\begin{tabular}{|l|} 
VFW-14-1 \\
$10 / 10 / 00$ \\
\end{tabular}} \\
\hline & $5 / 8 / 00$ & $10 / 10 / 00$ & & $5 / 8 / 00$ & $10 / 10 / 00$ & \\
\hline Benzo(b)fluoranthene & ND & ND & ND & ND & $\mathrm{ND}$ & ND \\
\hline Benzo(ghi)perylene & ND & ND & ND & ND & ND & ND \\
\hline Benzo(k)fluoranthene & ND & ND & ND & ND & ND & ND \\
\hline Bis(2-chloroethoxyl) methane & ND & ND & ND & ND & ND & ND \\
\hline Bis (2-chloroethyl) ether & ND & ND & ND & ND & ND & ND \\
\hline Bis(2-chloroisopropyl) ether & ND & ND & ND & ND & ND & ND \\
\hline Bis(2-ethylhexyl) phthalate & ND & ND & ND & ND & ND & ND \\
\hline Butyl benzyl phthalate & ND & ND & ND & ND & ND & ND \\
\hline Carbazole & ND & ND & ND & ND & $\mathrm{ND}$ & ND \\
\hline Chrysene & ND & ND & ND & ND & ND & ND \\
\hline Di-n-butyl phthalate & ND & ND & ND & ND & ND & ND \\
\hline Di-n-octly phthalate & $\mathrm{ND}$ & $\mathrm{ND}$ & $\mathrm{ND}$ & $\mathrm{ND}$ & $\mathrm{ND}$ & $\mathrm{ND}$ \\
\hline Dibenzo(a,h)anthracene & ND & ND & ND & ND & ND & ND \\
\hline Dibenzofuran & ND & ND & ND & ND & ND & ND \\
\hline Diethyl phthalate & ND & ND & ND & ND & ND & ND \\
\hline Dimethyl phthalate & ND & ND & ND & ND & ND & ND \\
\hline Fluoranthene & ND & ND & $\mathrm{ND}$ & ND & $\mathrm{ND}$ & $\mathrm{ND}$ \\
\hline Fluorene & ND & ND & ND & ND & ND & ND \\
\hline Hexachlorobenzene & ND & ND & ND & $\mathrm{ND}$ & ND & ND \\
\hline Hexachlorobutadiene & $\mathrm{ND}$ & ND & $\mathrm{ND}$ & $\mathrm{ND}$ & ND & ND \\
\hline Hexachlorocyclopentadiene & ND & ND & ND & ND & ND & ND \\
\hline Hexachloroethane & ND & ND & ND & ND & ND & ND \\
\hline Indeno(1,2,3-cd)pyrene & $\mathrm{ND}$ & $\mathrm{ND}$ & $\mathrm{ND}$ & $\mathrm{ND}$ & $\mathrm{ND}$ & $\mathrm{ND}$ \\
\hline Isophorone & ND & ND & ND & ND & ND & ND \\
\hline N-Nitroso-Di-n-propylamine & ND & ND & ND & ND & ND & ND \\
\hline N-nitrosodiphenylamine & ND & ND & ND & ND & ND & ND \\
\hline Naphthalene & ND & ND & ND & ND & ND & ND \\
\hline Nitrobenzene & ND & ND & ND & ND & $\mathrm{ND}$ & ND \\
\hline Pentachlorophenol & ND & ND & ND & ND & ND & ND \\
\hline Phenanthrene & ND & ND & ND & ND & ND & ND \\
\hline Phenol & $\mathrm{ND}$ & $\mathrm{ND}$ & ND & $\mathrm{ND}$ & $\mathrm{ND}$ & ND \\
\hline Pyrene & ND & ND & ND & ND & $\mathrm{ND}$ & ND \\
\hline
\end{tabular}

$\mathrm{ND}=$ not detected. 
Table 16. NETL-PGH 2000 Groundwater Detection Monitoring Program Results of Analysis - Groundwater Samples Valley Fill - TPH Constituents (mg/L)

\begin{tabular}{|c|c|c|c|c|c|c|c|c|c|}
\hline \multirow{3}{*}{$\begin{array}{l}\text { Constituent } \\
\text { Sample } \\
\text { Date }\end{array}$} & \multicolumn{9}{|c|}{ Well Number and Sample Date } \\
\hline & \multicolumn{2}{|c|}{ VFW-2 } & \multirow{2}{*}{$\begin{array}{c}\text { VFW-2-1 } \\
5 / 8 / 00\end{array}$} & \multicolumn{2}{|c|}{ VFW-4 } & \multicolumn{2}{|c|}{ VFW-7 } & \multicolumn{2}{|c|}{ VFW-9 } \\
\hline & $5 / 8 / 00$ & $10 / 10 / 00$ & & $5 / 8 / 00$ & $10 / 10 / 00$ & $5 / 8 / 00$ & $10 / 10 / 00$ & $5 / 8 / 00$ & $10 / 10 / 00$ \\
\hline TPH-DRO & ND & ND & ND & ND & ND & ND & ND & ND & ND \\
\hline \multirow{3}{*}{$\begin{array}{l}\text { Constituent } \\
\text { Sample } \\
\text { Date }\end{array}$} & \multicolumn{9}{|c|}{ Well Number and Sample Date } \\
\hline & \multicolumn{2}{|c|}{ VFW-10 } & \multicolumn{2}{|c|}{ VFW-11 } & \multicolumn{2}{|c|}{ VFW-12 } & VFW-12-1 & \multicolumn{2}{|c|}{ VFW-14 } \\
\hline & $5 / 8 / 00$ & $10 / 10 / 00$ & $5 / 8 / 00$ & $10 / 10 / 00$ & $5 / 8 / 00$ & $10 / 10 / 00$ & $10 / 10 / 00$ & $5 / 15 / 00$ & $10 / 10 / 00$ \\
\hline TPH-DRO & ND & ND & ND & ND & ND & ND & ND & ND & ND \\
\hline
\end{tabular}

$\mathrm{ND}=$ not detected; TPH = total petroleum hydrocarbons; TPH-DRO = total petroleum hydrocarbons and diesel range organics. 
Table 17. NETL-PGH 2000 Groundwater Detection Monitoring Program

Results of Analysis - Groundwater Samples, Main Plateau - Volatile Organic Compounds Constituents (Fg/L)

\begin{tabular}{|c|c|c|c|c|c|c|c|c|c|c|}
\hline \multirow{3}{*}{ Constituent } & \multicolumn{10}{|c|}{ Well Number and Sample Date } \\
\hline & \multicolumn{2}{|c|}{ MPW-1 } & \multicolumn{2}{|c|}{ MPW-7 } & \multicolumn{2}{|c|}{ MPW-7D } & \multicolumn{2}{|c|}{ MPW-8 } & \multicolumn{2}{|c|}{ MPW-9 } \\
\hline & $5 / 9 / 00$ & $10 / 11 / 00$ & $5 / 9 / 00$ & $10 / 11 / 00$ & $5 / 9 / 00$ & $10 / 11 / 00$ & $5 / 9 / 00$ & $10 / 11 / 00$ & $5 / 9 / 00$ & $10 / 11 / 00$ \\
\hline 1,1,1-Trichloroethane & ND & ND & ND & ND & ND & ND & ND & ND & ND & ND \\
\hline 1,1,2,2-Tetrachloroethane & ND & ND & $\mathrm{ND}$ & $\mathrm{ND}$ & $\mathrm{ND}$ & ND & $\mathrm{ND}$ & ND & ND & ND \\
\hline 1.12-Trichloroethane & $\mathrm{ND}$ & $\mathrm{ND}$ & $\mathrm{ND}$ & $\mathrm{ND}$ & $\mathrm{ND}$ & $\mathrm{ND}$ & $\mathrm{ND}$ & $\mathrm{ND}$ & $\mathrm{ND}$ & $N D$ \\
\hline 1,1-Dichloroethane & ND & ND & ND & ND & $\mathrm{ND}$ & $\mathrm{ND}$ & $\mathrm{ND}$ & ND & ND & ND \\
\hline 1.1-Dichloroethene & $\mathrm{ND}$ & $\mathrm{ND}$ & $\mathrm{ND}$ & $\mathrm{ND}$ & $\mathrm{ND}$ & $\mathrm{ND}$ & $\mathrm{ND}$ & $\mathrm{ND}$ & $\mathrm{ND}$ & $N D$ \\
\hline 1,2-Dichloroethane & ND & ND & ND & ND & $\mathrm{ND}$ & ND & ND & ND & ND & ND \\
\hline 1,2-Dichloropropane & ND & ND & ND & $\mathrm{ND}$ & ND & ND & ND & ND & ND & ND \\
\hline 2-Butanone (MEK) & $\mathrm{ND}$ & $\mathrm{ND}$ & $\mathrm{ND}$ & $\mathrm{ND}$ & $\mathrm{ND}$ & $\mathrm{ND}$ & $\mathrm{ND}$ & $\mathrm{ND}$ & $\mathrm{ND}$ & $\mathrm{ND}$ \\
\hline 2-Hexanone & $\mathrm{ND}$ & $\mathrm{ND}$ & ND & $\mathrm{ND}$ & $\mathrm{ND}$ & $\mathrm{ND}$ & $\mathrm{ND}$ & $\mathrm{ND}$ & ND & ND \\
\hline 4-Methyl-2-pentanone (MIBK) & $\mathrm{ND}$ & $\mathrm{ND}$ & $\mathrm{ND}$ & $\mathrm{ND}$ & $\mathrm{ND}$ & $\mathrm{ND}$ & $\mathrm{ND}$ & $\mathrm{ND}$ & $\mathrm{ND}$ & $N D$ \\
\hline Acetone & ND & ND & ND & ND & $\mathrm{ND}$ & $\mathrm{ND}$ & $\mathrm{ND}$ & ND & ND & ND \\
\hline Benzene & ND & ND & ND & ND & ND & ND & ND & ND & ND & ND \\
\hline Bromodichloromethane & $\mathrm{ND}$ & $\mathrm{ND}$ & $\mathrm{ND}$ & $\mathrm{ND}$ & $\mathrm{ND}$ & $\mathrm{ND}$ & $\mathrm{ND}$ & $\mathrm{ND}$ & $\mathrm{ND}$ & $\mathrm{ND}$ \\
\hline Bromoform & ND & ND & ND & ND & $\mathrm{ND}$ & ND & ND & ND & ND & ND \\
\hline Bromomethane & $\mathrm{ND}$ & $\mathrm{ND}$ & $\mathrm{ND}$ & $\mathrm{ND}$ & $\mathrm{ND}$ & $\mathrm{ND}$ & $\mathrm{ND}$ & $\mathrm{ND}$ & $\mathrm{ND}$ & $N D$ \\
\hline Carbon Disulfide & ND & ND & ND & ND & ND & ND & ND & ND & ND & ND \\
\hline Carbon Tetrachloride & ND & ND & ND & ND & $\mathrm{ND}$ & ND & ND & ND & ND & ND \\
\hline Chlorobenzene & $\mathrm{ND}$ & $\mathrm{ND}$ & $\mathrm{ND}$ & $\mathrm{ND}$ & $\mathrm{ND}$ & $\mathrm{ND}$ & $\mathrm{ND}$ & $\mathrm{ND}$ & $\mathrm{ND}$ & $\mathrm{ND}$ \\
\hline Chloroethane & ND & ND & ND & ND & $\mathrm{ND}$ & $\mathrm{ND}$ & $\mathrm{ND}$ & ND & ND & ND \\
\hline Chloroform & $\mathrm{ND}$ & $\mathrm{ND}$ & $\mathrm{ND}$ & $\mathrm{ND}$ & $\mathrm{ND}$ & $\mathrm{ND}$ & $\mathrm{ND}$ & $\mathrm{ND}$ & $\mathrm{ND}$ & $\mathrm{ND}$ \\
\hline Chloromethane & ND & ND & $\mathrm{ND}$ & $\mathrm{ND}$ & ND & ND & ND & ND & ND & ND \\
\hline cis-1,2-Dichloroethene & $\mathrm{ND}$ & $\mathrm{ND}$ & $\mathrm{ND}$ & $\mathrm{ND}$ & $\mathrm{ND}$ & $\mathrm{ND}$ & $\mathrm{ND}$ & $\mathrm{ND}$ & $\mathrm{ND}$ & $\mathrm{ND}$ \\
\hline cis-1.3-Dichloropropene & $\mathrm{ND}$ & $\mathrm{ND}$ & $\mathrm{ND}$ & $\mathrm{ND}$ & $\mathrm{ND}$ & $\mathrm{ND}$ & $\mathrm{ND}$ & $\mathrm{ND}$ & $\mathrm{ND}$ & $\mathrm{ND}$ \\
\hline Dibromochloromethane & ND & ND & $\mathrm{ND}$ & $\mathrm{ND}$ & $\mathrm{ND}$ & $\mathrm{ND}$ & $\mathrm{ND}$ & ND & ND & ND \\
\hline Ethylbenzene & $\mathrm{ND}$ & $\mathrm{ND}$ & $\mathrm{ND}$ & $\mathrm{ND}$ & $\mathrm{ND}$ & $\mathrm{ND}$ & $\mathrm{ND}$ & $\mathrm{ND}$ & $\mathrm{ND}$ & $\mathrm{ND}$ \\
\hline Methylene chloride & $\mathrm{ND}$ & ND & $\mathrm{ND}$ & $\mathrm{ND}$ & $\mathrm{ND}$ & ND & ND & ND & ND & $\mathrm{ND}$ \\
\hline Styrene & ND & ND & ND & ND & $\mathrm{ND}$ & ND & $\mathrm{ND}$ & ND & ND & ND \\
\hline Tetrachloroethene & $\mathrm{ND}$ & $\mathrm{ND}$ & $\mathrm{ND}$ & $\mathrm{ND}$ & $\mathrm{ND}$ & $\mathrm{ND}$ & $\mathrm{ND}$ & $\mathrm{ND}$ & $\mathrm{ND}$ & $\mathrm{ND}$ \\
\hline Toulene & $\mathrm{ND}$ & $\mathrm{ND}$ & $\mathrm{ND}$ & $\mathrm{ND}$ & $\mathrm{ND}$ & $\mathrm{ND}$ & $\mathrm{ND}$ & $\mathrm{ND}$ & $\mathrm{ND}$ & $\mathrm{ND}$ \\
\hline Total Xvlenes & $\mathrm{ND}$ & $\mathrm{ND}$ & $\mathrm{ND}$ & $\mathrm{ND}$ & $\mathrm{ND}$ & $\mathrm{ND}$ & $\mathrm{ND}$ & $\mathrm{ND}$ & $\mathrm{ND}$ & $\mathrm{ND}$ \\
\hline trans-1,2-Dichloroethene & ND & ND & ND & ND & $\mathrm{ND}$ & ND & ND & ND & ND & ND \\
\hline trans-1,3-Dichloropropene & ND & ND & ND & $\mathrm{ND}$ & $\mathrm{ND}$ & ND & ND & ND & ND & ND \\
\hline Trichloroethene & $\mathrm{ND}$ & $\mathrm{ND}$ & $\mathrm{ND}$ & $\mathrm{ND}$ & $\mathrm{ND}$ & $\mathrm{ND}$ & $\mathrm{ND}$ & $\mathrm{ND}$ & $\mathrm{ND}$ & $\mathrm{ND}$ \\
\hline Vinyl chloride & $\mathrm{ND}$ & ND & $\mathrm{ND}$ & ND & ND & $\mathrm{ND}$ & $\mathrm{ND}$ & $\mathrm{ND}$ & $\mathrm{ND}$ & ND \\
\hline
\end{tabular}

ND = not detected; MEK = methylethyl ketone; MIBK = methylisobutyl ketone. 
Table 17. NETL-PGH 2000 Groundwater Detection Monitoring Program

Results of Analysis - Groundwater Samples, Main Plateau - Volatile Organic Compounds Constituents (Fg/L)

(continued)

\begin{tabular}{|c|c|c|c|c|c|c|}
\hline \multirow{3}{*}{$\begin{array}{l}\text { Constituent } \\
\text { Sample Date: }\end{array}$} & \multicolumn{4}{|c|}{ Well Number and Sample Date } & & \\
\hline & \multicolumn{2}{|c|}{ MPW-10 } & \multicolumn{2}{|c|}{ MPW-11 } & \multicolumn{2}{|c|}{ MPW-12 } \\
\hline & $5 / 9 / 00$ & $10 / 11 / 00$ & $5 / 9 / 00$ & $10 / 11 / 00$ & $5 / 8 / 00$ & $10 / 10 / 00$ \\
\hline 1,1,1-Trichloroethane & ND & ND & ND & ND & ND & ND \\
\hline 1,1,2,2-Tetrachloroethane & $\mathrm{ND}$ & ND & ND & ND & ND & ND \\
\hline 1,1,2-Trichloroethane & $\mathrm{ND}$ & $\mathrm{ND}$ & $\mathrm{ND}$ & $\mathrm{ND}$ & $\mathrm{ND}$ & ND \\
\hline 1,1-Dichloroethane & ND & ND & ND & ND & ND & ND \\
\hline 1,1-Dichloroethene & $\mathrm{ND}$ & ND & ND & ND & ND & ND \\
\hline 1,2-Dichloroethane & $\mathrm{ND}$ & $\mathrm{ND}$ & $\mathrm{ND}$ & $\mathrm{ND}$ & $\mathrm{ND}$ & ND \\
\hline 1,2-Dichloropropane & $\mathrm{ND}$ & $\mathrm{ND}$ & ND & ND & ND & ND \\
\hline 2-Butanone (MEK) & $\mathrm{ND}$ & $\mathrm{ND}$ & $\mathrm{ND}$ & ND & $\mathrm{ND}$ & ND \\
\hline 2-Hexanone & $\mathrm{ND}$ & $\mathrm{ND}$ & $\mathrm{ND}$ & $\mathrm{ND}$ & ND & ND \\
\hline 4-Methyl-2-pentanone (MIBK) & $\mathrm{ND}$ & $\mathrm{ND}$ & $\mathrm{ND}$ & $\mathrm{ND}$ & $\mathrm{ND}$ & $\mathrm{ND}$ \\
\hline Acetone & $\mathrm{ND}$ & $\mathrm{ND}$ & $\mathrm{ND}$ & $\mathrm{ND}$ & $\mathrm{ND}$ & $\mathrm{ND}$ \\
\hline Benzene & $\mathrm{ND}$ & $\mathrm{ND}$ & $\mathrm{ND}$ & $\mathrm{ND}$ & $\mathrm{ND}$ & ND \\
\hline Bromodichloromethane & $\mathrm{ND}$ & $\mathrm{ND}$ & $\mathrm{ND}$ & $\mathrm{ND}$ & $\mathrm{ND}$ & $\mathrm{ND}$ \\
\hline Bromoform & ND & $\mathrm{ND}$ & $\mathrm{ND}$ & $\mathrm{ND}$ & $\mathrm{ND}$ & $\mathrm{ND}$ \\
\hline Bromomethane & ND & $\mathrm{ND}$ & $\mathrm{ND}$ & ND & $\mathrm{ND}$ & ND \\
\hline Carbon Disulfide & ND & $\mathrm{ND}$ & $\mathrm{ND}$ & ND & ND & ND \\
\hline Carbon Tetrachloride & $\mathrm{ND}$ & $\mathrm{ND}$ & $\mathrm{ND}$ & $\mathrm{ND}$ & $\mathrm{ND}$ & $\mathrm{ND}$ \\
\hline Chlorobenzene & $\mathrm{ND}$ & $\mathrm{ND}$ & $\mathrm{ND}$ & $\mathrm{ND}$ & ND & $\mathrm{ND}$ \\
\hline Chloroethane & ND & ND & ND & ND & ND & ND \\
\hline Chloroform & $\mathrm{ND}$ & ND & ND & ND & ND & ND \\
\hline Chloromethane & ND & ND & ND & ND & ND & ND \\
\hline cis-1,2-Dchloroethene & ND & ND & ND & ND & ND & ND \\
\hline cis-1,3-Dichloropropene & $\mathrm{ND}$ & $\mathrm{ND}$ & $\mathrm{ND}$ & $\mathrm{ND}$ & $\mathrm{ND}$ & ND \\
\hline Dibromochloromethane & ND & ND & ND & ND & ND & ND \\
\hline Ethylbenzene & $\mathrm{ND}$ & ND & ND & ND & ND & ND \\
\hline Methylene chloride & $\mathrm{ND}$ & $\mathrm{ND}$ & $\mathrm{ND}$ & $\mathrm{ND}$ & $\mathrm{ND}$ & $\mathrm{ND}$ \\
\hline Styrene & ND & ND & ND & ND & ND & ND \\
\hline Tetrachloroethene & $\mathrm{ND}$ & ND & ND & $\mathrm{ND}$ & ND & ND \\
\hline Toulene & ND & ND & ND & ND & ND & ND \\
\hline Total Xylenes & $\mathrm{ND}$ & $\mathrm{ND}$ & $\mathrm{ND}$ & $\mathrm{ND}$ & $\mathrm{ND}$ & $\mathrm{ND}$ \\
\hline trans-1,2-Dichloroethene & $\mathrm{ND}$ & $\mathrm{ND}$ & $\mathrm{ND}$ & $\mathrm{ND}$ & $\mathrm{ND}$ & $\mathrm{ND}$ \\
\hline trans-1,3-Dichloropropene & $\mathrm{ND}$ & $\mathrm{ND}$ & $\mathrm{ND}$ & $\mathrm{ND}$ & $\mathrm{ND}$ & $\mathrm{ND}$ \\
\hline Trichloroethene & ND & ND & ND & ND & ND & ND \\
\hline Vinyl chloride & ND & $\mathrm{ND}$ & $\mathrm{ND}$ & $\mathrm{ND}$ & $\mathrm{ND}$ & ND \\
\hline
\end{tabular}

ND = not detected; MEK = methylethyl ketone; MIBK = methylisobutyl ketone. 


\section{Table 18. NETL-PGH 2000 Groundwater Detection Monitoring Program Results of Analysis - Groundwater Samples, Valley Fill - Volatile Organic Compounds Constituents (Fg/L)}

\begin{tabular}{|c|c|c|c|c|c|c|c|c|c|c|}
\hline \multirow{3}{*}{ Constituent } & \multicolumn{10}{|c|}{ Well Number and Sample Date } \\
\hline & \multicolumn{2}{|c|}{ VFW-2 } & \multicolumn{2}{|c|}{ VFW-3 } & \multirow{2}{*}{\begin{tabular}{|c|} 
VFW-3-1 \\
$5 / 8 / 00$ \\
\end{tabular}} & \multicolumn{2}{|c|}{ VFW-10 } & \multirow{2}{*}{\begin{tabular}{|l|} 
VFW-10-1 \\
$10 / 10 / 00$
\end{tabular}} & \multicolumn{2}{|c|}{ VFW-14 } \\
\hline & $5 / 8 / 00$ & $10 / 10 / 00$ & $5 / 8 / 00$ & $10 / 10 / 00$ & & $5 / 8 / 00$ & $10 / 10 / 00$ & & $5 / 8 / 00$ & $10 / 10 / 00$ \\
\hline 1,1,1-Trichloroethane & ND & ND & ND & ND & ND & ND & ND & ND & ND & ND \\
\hline 1,1,2,2-Tetrachloroethane & ND & ND & ND & ND & ND & ND & ND & ND & ND & ND \\
\hline 1,1,2-Trichloroethane & ND & ND & ND & ND & ND & ND & $\mathrm{ND}$ & ND & ND & ND \\
\hline 1,1-Dichloroethane & ND & ND & ND & ND & ND & ND & ND & ND & ND & ND \\
\hline 1,1-Dichloroethene & ND & ND & ND & ND & ND & ND & ND & ND & $\mathrm{ND}$ & ND \\
\hline 1,2-Dichloroethane & $\mathrm{ND}$ & $\mathrm{ND}$ & $\mathrm{ND}$ & $\mathrm{ND}$ & $\mathrm{ND}$ & $\mathrm{ND}$ & $\mathrm{ND}$ & $\mathrm{ND}$ & $\mathrm{ND}$ & $\mathrm{ND}$ \\
\hline 1,2-Dichloropropane & ND & ND & ND & ND & ND & ND & ND & ND & ND & ND \\
\hline 2-Butanone (MEK) & ND & ND & ND & ND & ND & ND & ND & ND & ND & ND \\
\hline 2-Hexanone & $\mathrm{ND}$ & $\mathrm{ND}$ & $\mathrm{ND}$ & $\mathrm{ND}$ & ND & $\mathrm{ND}$ & $\mathrm{ND}$ & ND & $\mathrm{ND}$ & ND \\
\hline $\begin{array}{l}\text { 4-Methyl-2-pentanone } \\
\text { (MIBK) }\end{array}$ & ND & ND & ND & ND & ND & ND & ND & ND & ND & ND \\
\hline Acetone & $\mathrm{ND}$ & ND & $\mathrm{ND}$ & ND & ND & ND & $\mathrm{ND}$ & ND & $\mathrm{ND}$ & $\mathrm{ND}$ \\
\hline Benzene & $\mathrm{ND}$ & $\mathrm{ND}$ & $\mathrm{ND}$ & $\mathrm{ND}$ & $\mathrm{ND}$ & $\mathrm{ND}$ & $\mathrm{ND}$ & $\mathrm{ND}$ & $\mathrm{ND}$ & ND \\
\hline Bromodichloromethane & ND & ND & ND & ND & ND & ND & ND & ND & ND & ND \\
\hline Bromoform & $\mathrm{ND}$ & ND & ND & ND & ND & ND & ND & ND & $\mathrm{ND}$ & ND \\
\hline Bromomethane & ND & ND & ND & ND & ND & ND & ND & ND & ND & ND \\
\hline Carbon Disulfide & ND & ND & ND & ND & ND & ND & ND & ND & ND & ND \\
\hline Carbon Tetrachloride & $\mathrm{ND}$ & $\mathrm{ND}$ & $\mathrm{ND}$ & $\mathrm{ND}$ & ND & $\mathrm{ND}$ & $\mathrm{ND}$ & $\mathrm{ND}$ & $\mathrm{ND}$ & ND \\
\hline Chlorobenzene & ND & ND & ND & ND & ND & ND & ND & ND & ND & ND \\
\hline Chloroethane & ND & ND & ND & ND & ND & ND & ND & ND & ND & ND \\
\hline Chloroform & $\mathrm{ND}$ & $\mathrm{ND}$ & $\mathrm{ND}$ & ND & ND & ND & $\mathrm{ND}$ & ND & $\mathrm{ND}$ & ND \\
\hline Chloromethane & ND & ND & ND & ND & ND & ND & ND & ND & ND & ND \\
\hline cis-1,2-Dichloroethene & ND & ND & ND & ND & ND & ND & ND & ND & ND & ND \\
\hline cis-1,3-Dichloropropene & $\mathrm{ND}$ & $\mathrm{ND}$ & $\mathrm{ND}$ & $\mathrm{ND}$ & $\mathrm{ND}$ & $\mathrm{ND}$ & $\mathrm{ND}$ & $\mathrm{ND}$ & $\mathrm{ND}$ & $\mathrm{ND}$ \\
\hline Dibromochloromethane & ND & ND & ND & ND & ND & ND & ND & ND & ND & ND \\
\hline Ethylbenzene & ND & ND & ND & ND & ND & ND & ND & ND & ND & ND \\
\hline Methylene chloride & $\mathrm{ND}$ & ND & $\mathrm{ND}$ & ND & ND & ND & ND & ND & ND & ND \\
\hline Styrene & ND & ND & ND & ND & ND & ND & ND & ND & ND & ND \\
\hline Tetrachloroethene & ND & ND & ND & ND & ND & ND & ND & ND & ND & ND \\
\hline Toulene & ND & ND & ND & ND & ND & ND & ND & ND & ND & ND \\
\hline Total Xylenes & ND & ND & ND & ND & ND & ND & ND & ND & ND & ND \\
\hline trans-1,2-Dichloroethene & $\mathrm{ND}$ & $\mathrm{ND}$ & ND & $\mathrm{ND}$ & ND & $\mathrm{ND}$ & $\mathrm{ND}$ & ND & $\mathrm{ND}$ & $\mathrm{ND}$ \\
\hline trans-1,3-Dichloropropene & ND & ND & ND & ND & ND & ND & ND & ND & ND & ND \\
\hline Trichloroethene & ND & ND & ND & ND & ND & ND & ND & ND & ND & ND \\
\hline Vinyl chloride & ND & ND & ND & ND & ND & ND & ND & ND & ND & ND \\
\hline
\end{tabular}

$\mathrm{ND}=$ not detected; MEK = methylethyl ketone; MIBK = methylisobutyl ketone. 
Table 19. NETL-MGN March 2000 Groundwater Data for "Morgantown Aquifer"

\begin{tabular}{|c|c|c|c|c|}
\hline \multirow[b]{2}{*}{ Parameter } & \multicolumn{4}{|c|}{ Sample Location } \\
\hline & D1-M & D2-M & D3-M & D4-M \\
\hline $\mathrm{pH}(\mathrm{s} . \mathrm{u})$ & 7.3 & 8.88 & 7.98 & 7.1 \\
\hline Specific Conductance (Fmhos) & 320 & 507 & 425 & 337 \\
\hline Temperature (E C) & 15.6 & 14.2 & 13.4 & 14.5 \\
\hline Arsenic (total, mg/L) & 0.011 & ND & ND & ND \\
\hline Barium (total, mg/L) & 0.22 & 0.17 & 0.97 & 0.41 \\
\hline Cadmium (total, mg/L) & ND & ND & ND & ND \\
\hline Chromium (total, mg/L) & ND & ND & ND & ND \\
\hline Lead (total, mg/L) & ND & ND & ND & ND \\
\hline Mercury (total, mg/L) & ND & ND & ND & ND \\
\hline Selenium (total, mg/L) & ND & ND & ND & ND \\
\hline Silver (total, mg/L) & ND & ND & ND & ND \\
\hline Iron (total, mg/L) & 13 & 3.3 & ND & ND \\
\hline Manganese (total, mg/L) & 1.2 & 0.12 & 0.058 & ND \\
\hline Sodium (total, mg/L) & 6.7 & 140 & 38 & 18 \\
\hline Vanadium (total, mg/L) & ND & ND & ND & ND \\
\hline Benzene (mg/L) & ND & ND & ND & ND \\
\hline Toluene (mg/L) & ND & ND & ND & ND \\
\hline Ethylbenzene (mg/L) & ND & ND & ND & ND \\
\hline Total Xylenes (mg/L) & ND & ND & ND & ND \\
\hline Total Organic Halides (mg/L) & ND & ND & ND & ND \\
\hline Chloride (mg/L) & 12 & ND & ND & 37 \\
\hline Sulfate (mg/L) & 28 & 5.5 & 17 & 11 \\
\hline Nitrate Nitrogen $(\mathrm{mg} / \mathrm{L})$ & ND & 0.34 & 0.053 & 0.6 \\
\hline Fluoride (mg/L) & 0.08 & 0.52 & 0.17 & 0.16 \\
\hline Total Recoverable Phenolics (mg/L) & ND & ND & ND & ND \\
\hline Cyanide (total, mg/L) & ND & ND & ND & ND \\
\hline Total Organic Carbon (mg/L) & 2.1 & 2.5 & 1.9 & 1.4 \\
\hline Naphthalene (Fg/L) & ND & ND & ND & ND \\
\hline Other Semivolatiles & ND & ND & ND & ND \\
\hline
\end{tabular}


Table 20. NETL-MGN March 2000 Groundwater Data for "A Aquifer"

\begin{tabular}{|c|c|c|c|c|c|c|c|c|c|c|c|c|c|}
\hline \multirow[b]{2}{*}{ Parameter } & \multicolumn{13}{|c|}{ Sample Location } \\
\hline & $\bar{A}$ & B & SP1-A & SP4-A & SP8-A & SP9-A & I & $\bar{J}$ & $\mathbf{K}$ & $\mathbf{L}$ & $\bar{M}$ & $\mathbf{N}$ & $\overline{\text { GAS-4 }}$ \\
\hline $\mathrm{bH}(\mathrm{s} . \mathrm{u})$ & 6.67 & 6.38 & 7.06 & 7.13 & 6.44 & 6.6 & 6.05 & 5.14 & 4.59 & 4.92 & 4.28 & 4.59 & 6.56 \\
\hline Specific Conductance (Fmhos) & 189 & 211 & 230 & 241 & 350 & 992 & 516 & 768 & 1023 & 1370 & 318 & 668 & 565 \\
\hline Temperature (E C) & 14.5 & 14.5 & 14 & 16.4 & 14.5 & 14.2 & 15.3 & 15.4 & 13.2 & 15.9 & 11.8 & 14.9 & 16.4 \\
\hline Arsenic (total, mg/L) & $\mathrm{ND}$ & $\mathrm{ND}$ & $\mathrm{ND}$ & $\mathrm{ND}$ & $\mathrm{ND}$ & $\mathrm{ND}$ & 0.009 & $\mathrm{ND}$ & $\mathrm{ND}$ & $\mathrm{ND}$ & $\mathrm{ND}$ & $\mathrm{ND}$ & $\mathrm{ND}$ \\
\hline Barium (total, mg/L) & 0.4 & 0.22 & 0.13 & 0.038 & 0.35 & 0.16 & 0.5 & 0.21 & 0.097 & 0.12 & 0.028 & 0.14 & 0.27 \\
\hline Cadmium (total, mg/L) & $\mathrm{ND}$ & $\mathrm{ND}$ & $\mathrm{ND}$ & $\mathrm{ND}$ & $\mathrm{ND}$ & $\mathrm{ND}$ & $\mathrm{ND}$ & 0.001 & 0.003 & 0.008 & $\mathrm{ND}$ & 0.0013 & $\mathrm{ND}$ \\
\hline Chromium (total, $\mathrm{mg} / \mathrm{L}$ ) & $\mathrm{ND}$ & $\mathrm{ND}$ & $\mathrm{ND}$ & $\mathrm{ND}$ & $\mathrm{ND}$ & 0.028 & $\mathrm{ND}$ & $\mathrm{ND}$ & $\mathrm{ND}$ & $\mathrm{ND}$ & ND & $\mathrm{ND}$ & ND \\
\hline Lead (total, mg/L) & $\mathrm{ND}$ & $\mathrm{ND}$ & ND & $\mathrm{ND}$ & $\mathrm{ND}$ & $\mathrm{ND}$ & ND & $\mathrm{ND}$ & $\mathrm{ND}$ & $\mathrm{ND}$ & $\mathrm{ND}$ & $\mathrm{ND}$ & ND \\
\hline Mercury (total, mg/L) & $\mathrm{ND}$ & $\mathrm{ND}$ & $\mathrm{ND}$ & ND & $\mathrm{ND}$ & $\mathrm{ND}$ & ND & $\mathrm{ND}$ & $\mathrm{ND}$ & $\mathrm{ND}$ & 0.0002 & $\mathrm{ND}$ & 0.0003 \\
\hline Selenium (total, $\mathrm{mg} / \mathrm{L}$ ) & ND & ND & $\mathrm{ND}$ & $\mathrm{ND}$ & ND & $\mathrm{ND}$ & $\mathrm{ND}$ & ND & ND & ND & $\mathrm{ND}$ & ND & ND \\
\hline Silver (total, mg/L) & $\mathrm{ND}$ & $\mathrm{ND}$ & $\mathrm{ND}$ & $\mathrm{ND}$ & $\mathrm{ND}$ & $\mathrm{ND}$ & $\mathrm{ND}$ & $\mathrm{ND}$ & $\mathrm{ND}$ & $\mathrm{ND}$ & $\mathrm{ND}$ & $\mathrm{ND}$ & $\mathrm{ND}$ \\
\hline ron (total, mg/L) & 24 & 29 & 21 & 1.4 & 42 & 1 & 27 & 0.45 & 0.5 & 1.1 & 4.2 & 0.76 & 39 \\
\hline Manganese (total, mg/L) & 0.98 & 1.1 & 2.1 & 0.36 & 2.8 & 1.8 & 0.34 & 0.17 & 1.7 & 0.64 & 0.89 & 0.43 & 1.3 \\
\hline Sodium (total, mg/L) & 6.7 & 4.4 & 13 & 8.4 & 7.5 & 130 & 28 & 56 & 110 & 340 & 15 & 50 & 21 \\
\hline Vanadium (total, $\mathrm{mg} / \mathrm{L}$ ) & $\mathrm{ND}$ & $\mathrm{ND}$ & $\mathrm{ND}$ & $\mathrm{ND}$ & ND & ND & $\mathrm{ND}$ & $\mathrm{ND}$ & $\mathrm{ND}$ & $\mathrm{ND}$ & ND & ND & $\mathrm{ND}$ \\
\hline Benzene (mg/L) & $\mathrm{ND}$ & $\mathrm{ND}$ & $\mathrm{ND}$ & $\mathrm{ND}$ & $\mathrm{ND}$ & $\mathrm{ND}$ & $\mathrm{ND}$ & $\mathrm{ND}$ & $\mathrm{ND}$ & $\mathrm{ND}$ & $\mathrm{ND}$ & $\mathrm{ND}$ & $\mathrm{ND}$ \\
\hline Toluene (mg/L) & $\mathrm{ND}$ & $\mathrm{ND}$ & $\mathrm{ND}$ & $\mathrm{ND}$ & $\mathrm{ND}$ & $\mathrm{ND}$ & ND & $\mathrm{ND}$ & $\mathrm{ND}$ & $\mathrm{ND}$ & ND & $\mathrm{ND}$ & ND \\
\hline Ethylbenzene (mg/L) & ND & ND & ND & ND & ND & ND & ND & ND & ND & ND & ND & ND & ND \\
\hline Total Xylenes (mg/L) & $\mathrm{ND}$ & $\mathrm{ND}$ & $\mathrm{ND}$ & $\mathrm{ND}$ & $\mathrm{ND}$ & $\mathrm{ND}$ & ND & $\mathrm{ND}$ & $\mathrm{ND}$ & $\mathrm{ND}$ & ND & $\mathrm{ND}$ & $\mathrm{ND}$ \\
\hline Total Organic Halides (mg/L) & ND & ND & ND & ND & ND & ND & ND & ND & ND & ND & ND & ND & ND \\
\hline Chloride (mg/L) & $\mathrm{ND}$ & $\mathrm{ND}$ & $\mathrm{ND}$ & 29 & 50 & 310 & 94 & 190 & 250 & 1000 & 31 & 180 & 84 \\
\hline Sulfate $(\mathrm{mg} / \mathrm{L})$ & 13 & 21 & 64 & 24 & 26 & 54 & 50 & 50 & 77 & 120 & 87 & 57 & 53 \\
\hline Nitrate Nitrogen $(\mathrm{mg} / \mathrm{L})$ & 0.06 & ND & 0.09 & 0.052 & 0.1 & 1 & ND & 0.71 & 0.99 & 4.2 & 0.18 & 0.49 & 0.15 \\
\hline Fluoride (mg/L) & 0.07 & 0.06 & 0.05 & 0.11 & 0.06 & ND & 0.06 & $\mathrm{ND}$ & 0.39 & 0.48 & 0.15 & 0.07 & 0.096 \\
\hline Total Recoverable Phenolics (mg/L) & $\mathrm{ND}$ & $\mathrm{ND}$ & ND & ND & $\mathrm{ND}$ & $\mathrm{ND}$ & $\mathrm{ND}$ & $\mathrm{ND}$ & ND & ND & $\mathrm{ND}$ & $\mathrm{ND}$ & ND \\
\hline Cyanide (total, mg/L) & $\mathrm{ND}$ & $\mathrm{ND}$ & $\mathrm{ND}$ & $\mathrm{ND}$ & $\mathrm{ND}$ & $\mathrm{ND}$ & $\mathrm{ND}$ & $\mathrm{ND}$ & $\mathrm{ND}$ & $\mathrm{ND}$ & $\mathrm{ND}$ & $\mathrm{ND}$ & $\mathrm{ND}$ \\
\hline Total Organic Carbon (mg/L) & 2.2 & 1.9 & 2.1 & 1.5 & 2.7 & 1.4 & 2.2 & 1.2 & 1.8 & 2.3 & 2.2 & 1.3 & 5.1 \\
\hline Naphthalene (Fg/L) & ND & $\mathrm{ND}$ & ND & ND & ND & $\mathrm{ND}$ & ND & ND & ND & ND & ND & ND & ND \\
\hline Other Semivolatiles & $\mathrm{ND}$ & $\mathrm{ND}$ & $\mathrm{ND}$ & $\mathrm{ND}$ & $\mathrm{ND}$ & $\mathrm{ND}$ & $\mathrm{ND}$ & $\mathrm{ND}$ & $\mathrm{ND}$ & $\mathrm{ND}$ & $\mathrm{ND}$ & $\mathrm{ND}$ & $\mathrm{ND}$ \\
\hline
\end{tabular}


Table 21. NETL-MGN March 2000 Groundwater Data for "B-C Aquifer"

\begin{tabular}{|c|c|c|c|c|c|}
\hline \multirow[b]{2}{*}{ Parameter } & \multicolumn{5}{|c|}{ Sample Location } \\
\hline & 11 & SP2-BC & $32 \mathrm{~A}$ & 31 & GAS-5 \\
\hline $\mathrm{pH}(\mathrm{s} . \mathrm{u})$ & 6.32 & 7.69 & 4.91 & 5.25 & 6.74 \\
\hline Specific Conductance (Fmhos) & 1225 & 467 & 1010 & 720 & 749 \\
\hline Temperature (E C) & 14.8 & 14.6 & 12.6 & 15.9 & 14.8 \\
\hline Arsenic (total, mg/L) & ND & ND & ND & ND & ND \\
\hline Barium (total, mg/L) & 0.11 & 0.043 & 0.044 & 0.10 & 0.11 \\
\hline Cadmium (total, mg/L) & ND & ND & 0.0014 & ND & ND \\
\hline Chromium (total, mg/L) & ND & ND & ND & $\mathrm{ND}$ & ND \\
\hline Lead (total, mg/L) & ND & ND & ND & $\mathrm{ND}$ & ND \\
\hline Mercury (total, mg/L) & ND & ND & ND & $\mathrm{ND}$ & ND \\
\hline Selenium (total, $\mathrm{mg} / \mathrm{L}$ ) & ND & ND & ND & $\mathrm{ND}$ & ND \\
\hline Silver (total, mg/L) & ND & ND & ND & $\mathrm{ND}$ & ND \\
\hline Iron (total, mg/L) & 22 & 0.66 & ND & 0.6 & 16 \\
\hline Manganese (total, mg/L) & 0.77 & 0.15 & 2 & 5.8 & 0.48 \\
\hline Sodium (total, mg/L) & 3.6 & 3.4 & 140 & 63 & 46 \\
\hline Vanadium (total, mg/L) & ND & ND & ND & ND & ND \\
\hline Benzene (mg/L) & ND & ND & ND & $\mathrm{ND}$ & ND \\
\hline Toluene (mg/L) & ND & ND & ND & $\mathrm{ND}$ & ND \\
\hline Ethylbenzene (mg/L) & ND & ND & ND & $\mathrm{ND}$ & ND \\
\hline Total Xylenes (mg/L) & ND & ND & ND & $\mathrm{ND}$ & ND \\
\hline Total Organic Halides (mg/L) & ND & ND & ND & ND & ND \\
\hline Chloride (mg/L) & 5.3 & 6.3 & 350 & 170 & 140 \\
\hline Sulfate (mg/L) & 15 & 17 & 110 & 62 & 110 \\
\hline Nitrate Nitrogen (mg/L) & 0.06 & 0.27 & 1.1 & 1.4 & 0.15 \\
\hline Fluoride (mg/L) & 0.06 & 0.1 & 0.18 & 0.06 & 0.15 \\
\hline Total Recoverable Phenolics (mg/L) & ND & ND & ND & ND & ND \\
\hline Cyanide (total, mg/L) & ND & ND & ND & ND & ND \\
\hline Total Organic Carbon (mg/L) & 1.3 & 2 & 2.1 & 2.1 & 4.4 \\
\hline Naphthalene (ug/L) & ND & ND & ND & $\mathrm{ND}$ & ND \\
\hline Other Semivolatiles & ND & ND & ND & $\mathrm{ND}$ & ND \\
\hline
\end{tabular}

$\mathrm{ND}=$ not detected; s.u. $=$ standard units. 
Table 22. NETL-MGN August 2000 Groundwater Data for "Morgantown Aquifer"

\begin{tabular}{|c|c|c|c|c|}
\hline \multirow[b]{2}{*}{ Parameter } & \multicolumn{4}{|c|}{ Sample Location } \\
\hline & D1M & D2M & D3M & D4M \\
\hline $\mathrm{pH}(\mathrm{s} . \mathrm{u})$ & 6.57 & 8.25 & 7.37 & 6.58 \\
\hline Specific Conductance (Fmhos) & 314 & 488 & 443 & 340 \\
\hline Temperature (E C) & 16 & 16.4 & 14.6 & 15.6 \\
\hline Arsenic (total, mg/L) & 0.012 & ND & ND & ND \\
\hline Barium (total, mg/L) & 0.23 & 0.16 & 0.97 & 0.48 \\
\hline Cadmium (total, mg/L) & ND & ND & ND & ND \\
\hline Chromium (total, mg/L) & ND & $\mathrm{ND}$ & ND & ND \\
\hline Lead (total, mg/L) & ND & $\mathrm{ND}$ & ND & $\mathrm{ND}$ \\
\hline Mercury (total, $\mathrm{mg} / \mathrm{L}$ ) & $\mathrm{ND}$ & $\mathrm{ND}$ & $\mathrm{ND}$ & ND \\
\hline Selenium (total, mg/L) & ND & ND & ND & ND \\
\hline Silver (total, mg/L) & ND & $\mathrm{ND}$ & ND & ND \\
\hline Iron (total, $\mathrm{mg} / \mathrm{L}$ ) & 16 & 2.3 & ND & ND \\
\hline Manganese (total, mg/L) & 1.4 & 0.17 & 0.065 & ND \\
\hline Sodium (total, mg/L) & 8.7 & 150 & 40 & 18 \\
\hline Vanadium (total, mg/L) & ND & ND & ND & ND \\
\hline Benzene (mg/L) & ND & $\mathrm{ND}$ & ND & ND \\
\hline Toluene (mg/L) & ND & $\mathrm{ND}$ & ND & ND \\
\hline Ethylbenzene (mg/L) & ND & ND & ND & ND \\
\hline Total Xylenes (mg/L) & ND & $\mathrm{ND}$ & $\mathrm{ND}$ & ND \\
\hline Total Organic Halides (mg/L) & ND & $\mathrm{ND}$ & ND & ND \\
\hline Chloride (mg/L) & 21 & ND & ND & 44 \\
\hline Sulfate $(\mathrm{mg} / \mathrm{L})$ & 39 & 3.8 & 17 & 9.8 \\
\hline Nitrate Nitrogen (mg/L) & ND & 0.29 & 0.072 & 0.44 \\
\hline Fluoride (mg/L) & 0.075 & 0.54 & 0.18 & 0.12 \\
\hline Total Recoverable Phenolics (mg/L) & ND & $\mathrm{ND}$ & ND & ND \\
\hline Cyanide (total, mg/L) & ND & ND & ND & ND \\
\hline Total Organic Carbon (mg/L) & 2.8 & 3.8 & 2.8 & 2.1 \\
\hline Naphthalene (Fg/L) & ND & ND & ND & ND \\
\hline Other Semivolatiles & ND & ND & ND & ND \\
\hline
\end{tabular}

$\mathrm{ND}$ = not detected; s.u. = standard units. 
Table 23. NETL-MGN August 2000 Groundwater Data for "A Aquifer"

\begin{tabular}{|c|c|c|c|c|c|c|c|c|c|c|c|c|c|}
\hline \multirow{2}{*}{ Parameter } & \multicolumn{13}{|c|}{ Sample Location } \\
\hline & A & B & SP1A & SP4-A & SP8A & SP9A & $\mathrm{I}$ & $\mathbf{J}$ & $\mathrm{K}$ & $\mathbf{L}$ & $M$ & $\mathbf{N}$ & GAS-4 \\
\hline $\mathrm{pH}(\mathrm{s} . \mathrm{u})$ & 6.37 & 6.15 & 6.3 & 6.34 & 6.03 & 5.6 & 6.05 & 5.35 & 4.96 & 6.07 & 4.34 & 4.89 & 6.43 \\
\hline Specific Conductance (Fmhos) & 260 & 225 & 100 & 209 & 326 & 1475 & 458 & 608 & 602 & 943 & 332 & 558 & 678 \\
\hline Temperature (E C) & 16.8 & 16.3 & 15.8 & 16.4 & 16.7 & 16 & 15.2 & 14.2 & 18.8 & 12.4 & 22 & 18.8 & 16.8 \\
\hline Arsenic (total, mg/L) & $\mathrm{ND}$ & $\mathrm{ND}$ & $\mathrm{ND}$ & $\mathrm{ND}$ & $\mathrm{ND}$ & $\mathrm{ND}$ & 0.02 & $\mathrm{ND}$ & $\mathrm{ND}$ & $\mathrm{ND}$ & $\mathrm{ND}$ & $\mathrm{ND}$ & $\mathrm{ND}$ \\
\hline Barium (total, mg/L) & 0.39 & 0.26 & 0.15 & 0.045 & 0.35 & 0.22 & 1.1 & 0.24 & 0.21 & 0.059 & 0.044 & 0.14 & 0.27 \\
\hline Cadmium (total, mg/L) & $\mathrm{ND}$ & $\mathrm{ND}$ & $\mathrm{ND}$ & $\mathrm{ND}$ & $\mathrm{ND}$ & 0.0011 & 0.0006 & 0.0009 & 0.002 & 0.002 & 0.0006 & 0.0015 & $\mathrm{ND}$ \\
\hline Chromium (total, mg/L) & $\mathrm{ND}$ & $\mathrm{ND}$ & $\mathrm{ND}$ & $\mathrm{ND}$ & $\mathrm{ND}$ & $\mathrm{ND}$ & $\mathrm{ND}$ & $\mathrm{ND}$ & $\mathrm{ND}$ & $\mathrm{ND}$ & $\mathrm{ND}$ & $\mathrm{ND}$ & $\mathrm{ND}$ \\
\hline Lead (total, mg/L) & $\mathrm{ND}$ & $\mathrm{ND}$ & $\mathrm{ND}$ & $\mathrm{ND}$ & $\mathrm{ND}$ & $\mathrm{ND}$ & $\mathrm{ND}$ & $\mathrm{ND}$ & $\mathrm{ND}$ & $\mathrm{ND}$ & $\mathrm{ND}$ & $\mathrm{ND}$ & ND \\
\hline Mercury (total, mg/L) & $\mathrm{ND}$ & $\mathrm{ND}$ & $\mathrm{ND}$ & ND & $\mathrm{ND}$ & $\mathrm{ND}$ & $\mathrm{ND}$ & $\mathrm{ND}$ & $\mathrm{ND}$ & $\mathrm{ND}$ & ND & ND & $\mathrm{ND}$ \\
\hline Selenium (total, $\mathrm{mg} / \mathrm{L}$ ) & $\mathrm{ND}$ & $\mathrm{ND}$ & $\mathrm{ND}$ & $\mathrm{ND}$ & $\mathrm{ND}$ & $\mathrm{ND}$ & $\mathrm{ND}$ & $\mathrm{ND}$ & $\mathrm{ND}$ & 0.0092 & $\mathrm{ND}$ & $\mathrm{ND}$ & $\mathrm{ND}$ \\
\hline Silver (total, mg/L) & $\mathrm{ND}$ & $\mathrm{ND}$ & $\mathrm{ND}$ & $\mathrm{ND}$ & $\mathrm{ND}$ & $\mathrm{ND}$ & $\mathrm{ND}$ & $\mathrm{ND}$ & $\mathrm{ND}$ & $\mathrm{ND}$ & $\mathrm{ND}$ & $\mathrm{ND}$ & $\mathrm{ND}$ \\
\hline Iron (total, $\mathrm{mg} / \mathrm{L}$ ) & 22 & 36 & 44 & 1.4 & 45 & 0.49 & 64 & 1.5 & $\mathrm{ND}$ & 1.5 & 3.5 & 0.48 & 37 \\
\hline Manganese (total, $\mathrm{mg} / \mathrm{L}$ ) & 1.1 & 1.4 & 1.8 & 0.56 & 3 & 2.8 & 0.45 & 0.11 & 0.63 & 0.17 & 1.3 & 0.4 & 0.86 \\
\hline Sodium (total, $\mathrm{mg} / \mathrm{L}$ ) & 7.9 & 5.9 & 15 & 8.9 & 9 & 180 & 19 & 61 & 69 & 180 & 25 & 61 & 21 \\
\hline Vanadium (total, mg/L) & $\mathrm{ND}$ & ND & $\mathrm{ND}$ & $\mathrm{ND}$ & $\mathrm{ND}$ & $\mathrm{ND}$ & $\mathrm{ND}$ & $\mathrm{ND}$ & $\mathrm{ND}$ & $\mathrm{ND}$ & $\mathrm{ND}$ & ND & $\mathrm{ND}$ \\
\hline Benzene (mg/L) & $\mathrm{ND}$ & $\mathrm{ND}$ & $\mathrm{ND}$ & $\mathrm{ND}$ & $\mathrm{ND}$ & $\mathrm{ND}$ & $\mathrm{ND}$ & $\mathrm{ND}$ & $\mathrm{ND}$ & $\mathrm{ND}$ & $\mathrm{ND}$ & ND & $\mathrm{ND}$ \\
\hline Toluene (mg/L) & $\mathrm{ND}$ & ND & $\mathrm{ND}$ & $\mathrm{ND}$ & $\mathrm{ND}$ & $\mathrm{ND}$ & $\mathrm{ND}$ & $\mathrm{ND}$ & $\mathrm{ND}$ & $\mathrm{ND}$ & $\mathrm{ND}$ & ND & ND \\
\hline Ethylbenzene (mg/L) & $\mathrm{ND}$ & ND & $\mathrm{ND}$ & $\mathrm{ND}$ & $\mathrm{ND}$ & $\mathrm{ND}$ & $\mathrm{ND}$ & $\mathrm{ND}$ & $\mathrm{ND}$ & $\mathrm{ND}$ & $\mathrm{ND}$ & ND & ND \\
\hline Total Xylenes (mg/L) & $\mathrm{ND}$ & $\mathrm{ND}$ & $\mathrm{ND}$ & $\mathrm{ND}$ & $\mathrm{ND}$ & $\mathrm{ND}$ & $\mathrm{ND}$ & $\mathrm{ND}$ & $\mathrm{ND}$ & $\mathrm{ND}$ & $\mathrm{ND}$ & $\mathrm{ND}$ & $\mathrm{ND}$ \\
\hline Total Organic Halides (mg/L) & $\mathrm{ND}$ & ND & $\mathrm{ND}$ & $\mathrm{ND}$ & $\mathrm{ND}$ & $\mathrm{ND}$ & $\mathrm{ND}$ & $\mathrm{ND}$ & $\mathrm{ND}$ & $\mathrm{ND}$ & $\mathrm{ND}$ & ND & $\mathrm{ND}$ \\
\hline Chloride (mg/L) & $\mathrm{ND}$ & ND & $\mathrm{ND}$ & 29 & 47 & 420 & 92 & 180 & 110 & 270 & 43 & 180 & 100 \\
\hline Sulfate $(\mathrm{mg} / \mathrm{L})$ & 25 & 42 & 66 & 25 & 17 & 79 & 170 & 52 & 40 & 150 & 99 & 66 & 63 \\
\hline Nitrate Nitrogen (mg/L) & $\mathrm{ND}$ & ND & $\mathrm{ND}$ & $\mathrm{ND}$ & $\mathrm{ND}$ & 0.81 & $\mathrm{ND}$ & 0.74 & 1.5 & 3 & 0.15 & 0.63 & 0.12 \\
\hline Fluoride $(\mathrm{mg} / \mathrm{L})$ & 0.078 & 0.1 & 0.068 & 0.092 & 0.084 & 0.071 & $\mathrm{ND}$ & 0.062 & 0.14 & 0.2 & 0.16 & 0.069 & 0.073 \\
\hline Total Recoverable Phenolics (mg/L) & ND & $\mathrm{ND}$ & $\mathrm{ND}$ & $\mathrm{ND}$ & $\mathrm{ND}$ & $\mathrm{ND}$ & $\mathrm{ND}$ & $\mathrm{ND}$ & $\mathrm{ND}$ & ND & $\mathrm{ND}$ & $\mathrm{ND}$ & $\mathrm{ND}$ \\
\hline Cyanide (total, $\mathrm{mg} / \mathrm{L}$ ) & $\mathrm{ND}$ & $\mathrm{ND}$ & ND & $\mathrm{ND}$ & $\mathrm{ND}$ & $\mathrm{ND}$ & $\mathrm{ND}$ & $\mathrm{ND}$ & $\mathrm{ND}$ & $\mathrm{ND}$ & $\mathrm{ND}$ & ND & ND \\
\hline Total Organic Carbon (mg/L) & 2.4 & 2.6 & 4 & 1.2 & 3.6 & 1.7 & 3.7 & 2 & 2.5 & 5.1 & 2.5 & 2.7 & 7.1 \\
\hline Naphthalene (Fg/L) & $\mathrm{ND}$ & ND & $\mathrm{ND}$ & $\mathrm{ND}$ & $\mathrm{ND}$ & $\mathrm{ND}$ & $\mathrm{ND}$ & $\mathrm{ND}$ & $\mathrm{ND}$ & $\mathrm{ND}$ & $\mathrm{ND}$ & ND & $\mathrm{ND}$ \\
\hline Other Semivolatiles & $\mathrm{ND}$ & ND & ND & ND & ND & ND & $\mathrm{ND}$ & ND & ND & ND & ND & ND & ND \\
\hline
\end{tabular}


Table 24. NETL-MGN August 2000 Groundwater Data for "B-C Aquifer"

\begin{tabular}{|c|c|c|c|c|c|}
\hline \multirow{2}{*}{ Parameter } & \multicolumn{5}{|c|}{ Sample Location } \\
\hline & 11 & SP2-BC & $32 \mathrm{~A}$ & 31 & GAS-5 \\
\hline $\mathrm{pH}(\mathrm{s} . \mathrm{u})$ & 6.16 & 6.5 & 4.89 & 5.55 & 6.81 \\
\hline Specific Conductance (F mhos) & 153 & 215 & 933 & 636 & 531 \\
\hline Temperature (E C) & 15.7 & 15.9 & 17.2 & 15.3 & 17.1 \\
\hline Arsenic (total, mg/L) & ND & ND & ND & ND & ND \\
\hline Barium (total, mg/L) & 0.12 & 0.031 & 0.055 & 0.11 & 0.17 \\
\hline Cadmium (total, mg/L) & ND & ND & 0.0021 & ND & ND \\
\hline Chromium (total, mg/L) & ND & ND & ND & ND & ND \\
\hline Lead (total, mg/L) & ND & ND & ND & ND & ND \\
\hline Mercury (total, mg/L) & ND & ND & ND & ND & ND \\
\hline Selenium (total, mg/L) & ND & ND & ND & ND & ND \\
\hline Silver (total, mg/L) & ND & ND & ND & ND & ND \\
\hline Iron (total, mg/L) & 22 & ND & ND & 1.1 & 4.3 \\
\hline Manganese (total, mg/L) & 0.9 & 0.081 & 2.5 & 8.1 & 2.7 \\
\hline Sodium (total, mg/L) & 4.6 & 4.5 & 180 & 89 & 57 \\
\hline Vanadium (total, mg/L) & ND & ND & ND & ND & ND \\
\hline Benzene (mg/L) & ND & ND & ND & ND & ND \\
\hline Toluene (mg/L) & ND & ND & ND & ND & ND \\
\hline Ethylbenzene (mg/L) & ND & ND & ND & ND & ND \\
\hline Total Xylenes (mg/L) & ND & ND & ND & ND & ND \\
\hline Total Organic Halides (mg/L) & ND & $\mathrm{ND}$ & ND & $\mathrm{ND}$ & $\mathrm{ND}$ \\
\hline Chloride (mg/L) & 5.8 & 7.2 & 420 & 190 & 120 \\
\hline Sulfate (mg/L) & 18 & 17 & 99 & 53 & 85 \\
\hline Nitrate Nitrogen (mg/L) & ND & 0.46 & 1.2 & ND & ND \\
\hline Fluoride (mg/L) & 0.067 & 0.097 & 0.15 & 0.071 & 0.12 \\
\hline Total Recoverable Phenolics (mg/L) & ND & 0.011 & ND & ND & ND \\
\hline Cyanide (total, mg/L) & ND & ND & ND & ND & ND \\
\hline Total Organic Carbon (mg/L) & 1.9 & 4.5 & 2.8 & 3.1 & 5.8 \\
\hline Naphthalene (Fg/L) & ND & ND & ND & ND & ND \\
\hline Other Semivolatiles & ND & ND & ND & ND & ND \\
\hline
\end{tabular}

